\author{
UNIVERSIDADE DE SÃO PAULO \\ FACULDADE DE FILOSOFIA, LETRAS E CIÊNCIAS HUMANAS \\ DEPARTAMENTO DE LETRAS CLÁSSICAS E VERNÁCULAS \\ PROGRAMA DE PÓS-GRADUAÇÃO EM LETRAS CLÁSSICAS
}

\title{
AS REVOLUÇÕES DA ALMA: SONHO E PRODIÁGNOSIS NO TRATADO HIPOCRÁTICO DA DIETA
}

\section{Versão corrigida}

Julieta Alsina

Tese apresentada ao Programa de Pós-Graduação em Letras Clássicas do Departamento de Letras Clássicas e Vernáculas da Faculdade de Filosofia, Letras e Ciências Humanas da Universidade de São Paulo, para a obtenção do título de Doutor em Letras Clássicas.

Orientador: Prof. Dr. Henrique Fortuna Cairus

São Paulo

2015 
Alsina, Julieta

Ar As revoluções da alma: Sonho e Prodiágnosis no tratado hipocrático $D a$ dieta / Julieta Alsina ; orientador Henrique Fortuna Cairus. - São Paulo, 2015. f. 138

Tese (Doutorado)- Faculdade de Filosofia, Letras e Ciências Humanas da Universidade de São Paulo. Departamento de Letras Clássicas e Vernáculas. Área de concentração: Letras Clássicas.

1. Corpus hippocraticum. 2. Dietética antiga. 3. Interpretação dos sonhos. 4. Conceito de alma. 5. Conceito de saúde. I. Cairus, Henrique Fortuna, orient. II. Título. 
ALSINA, Julieta. As revoluções da alma: Sonho e Prodiágnosis no tratado hipocrático Da dieta. Tese de Doutorado em Letras Clássicas. São Paulo: Universidade de São Paulo, 2015. $138 \mathrm{pp}$.

Tese examinada por:

Prof. Doutor Henrique Fortuna Cairus (PPGLC-USP)

Prof. Doutor Paulo Martins (PPGLC-USP)

Profa. Doutora Tatiana Oliveira Ribeiro (UFRJ)

Prof. Doutor Roberto Bolzani Filho (PPGF-USP)

Prof. Doutora Ana Thereza Basilio Vieira (UFRJ)

Prof. Doutor Marcos Martinho do Santos (PPGLC-USP) - suplente

Profa. Doutora Elaine Cristine Sartorelli (USP) - suplente

São Paulo, __ de maio de 2015. 


\section{Resumo}

\section{As revoluções da alma: Sonho e Prodiágnosis no tratado hipocrático Da dieta.}

O tema desta Tese é a interpretação dos sonhos no tratado hipocrático Da dieta, como uma forma de conhecimento do corpo. Trata-se de uma forma de mapeamento das perturbações do corpo que não são evidentes a uma mera observação diagnóstica e que serve como um tipo específico de prognose para a manutenção da saúde: a prodiagnose. $\mathrm{O}$ conhecimento e reconhecimento dos sonhos enquanto material da prodiagnose depende da compreensão do processo de conformação do corpo e da alma, que ocorre por meio da apomímesis tồ hólou. Essa apomímesis supõe uma relação analógica de correspondência e reciprocidade entre uma esfera macrocósmica relativa aos elementos de uma parte da phýsis que é imutável, e uma microcósmica, relativa ao corpo, que, por sua vez possui elementos da phýsis passíveis de modificação por meio da dieta. A Tese procura mapear nos escritos hipocráticos coevos ao Da dieta elementos que deem conta de delinear uma conceituação do sono, do sonho, da alma e do corpo. 


\begin{abstract}
The soul revolution: Dream and Prodiágnosis in the hippocratic treatise On Regimen
\end{abstract}

The theme of this Thesis is the interpretation of dreams in the Hippocratic treatise On Regimen, considered as a form of body knowledge. This body knowledge is a form of mapping bodily disorders that are not visible to a mere medical diagnosis, and also configures itself as a specific type of prognosis in regard of health maintenance: the prodiagnosis. The knowledge and recognition of dreams as prodiagnosis material depends on the understanding of body and soul formation processes, which occur by the concept of apomímesis toû hólou. This apomímesis could be considered as an analog relationship of correspondence and reciprocity between a macrocosmic sphere, regarding a part of physsis which is immutable, and a microcosmic sphere of the body, which, on the other hand, has some elements of physis that can be modified through diet. The thesis seeks to link some coeval Hippocratic writings to that of On regimen that give account to draw up the concepts of sleep, dream, soul and body. 
A Elba, que, de la semilla de su alma, hizo brotar el amor y la fuerza de seguir adelante. 


\section{Agradecimentos}

À Capes e ao PPGLC-USP, pela bolsa concedida.

Ao Professor Henrique Cairus, pela orientação sempre atenta, mas, principalmente, por acompanhar com zelo paternal a minha formação desde os primórdios da graduação.

Ao Professor Paulo Martins, pela "barriga de aluguel”.

Aos Professores e colegas do Programa de Altos Estudos em Representações da Antiguidade (Proaera), por, a cada encontro, oferecerem valiosas contribuições à minha pesquisa.

Ao Seminário São José, principalmente ao Pe. Álvaro José Assunção Inácio da Silva, à Vera Lúcia Barbosa Billion de Carvalho e a todos os alunos que pelas aulas de grego passaram, pela oportunidade de crescer enquanto professora.

À Professora Tatiana Ribeiro, pela grande amizade, pela interlocução, pela constante preocupação, pelas inúmeras bibliografias compartilhadas.

À Professora Beatriz de Paoli, pelos artigos gentilmente cedidos e pela disposição gentil.

Aos afetos, pelo carinho, pela paciência e pela torcida na saída da caverna.

Aos que não mais estão entre nós, mas que deixaram marca indelével no que eu sou: minha avó Segunda, Enrique Martinez, Leopoldo Bartolomé.

À minha família de allá ité: Alicia, Marisa, Marcos, Betty, Gastón, Jeremías, Selene, Martina, Anita, Ignacio e Sofía.

À minha família daqui: Gustavo, Solange, Ricardo, Flavia, Antonio, Bento e Maria.

Aos meus pais, Rocío e Luis.

Ao meu irmão amado, Juancito.

Ao meu companheiro para a vida toda, Guilherme.

Aos meus "filhos peludos", Nina, Bibi e Simão. 


\section{SUMÁRIO}

\begin{tabular}{|c|c|}
\hline I - Introdução & 10 \\
\hline 1 - O sono na literatura hipocrática & 35 \\
\hline 2 - O sonho na literatura hipocrática & 53 \\
\hline 3 - A alma no Da dieta & 68 \\
\hline 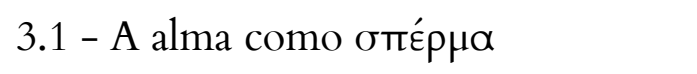 & 69 \\
\hline 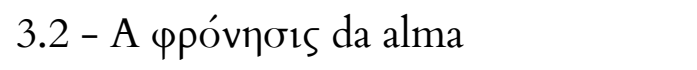 & 79 \\
\hline 3.3 - 'Апоні́нпбเs & 92 \\
\hline 4 - O livro IV do tratado Da dieta & 101 \\
\hline 4.1 - Apresentação do Da dieta IV & 101 \\
\hline 4.2 - Tradução integral do Da dieta IV & 113 \\
\hline
\end{tabular}

A hermenêutica dos sonhos na medicina antiga: entre o presente e o futuro

III - Bibliografia 
$[\ldots]$

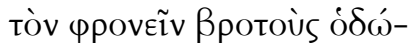

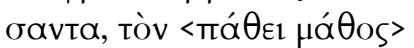

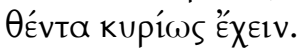

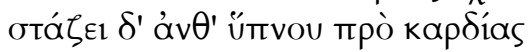

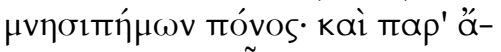
kovtas $\tilde{\eta} \lambda \theta \varepsilon \sigma \omega \varphi \rho O v \varepsilon \tilde{v}$.

Ésquilo, Agamêmnon, vv.176-181 


\section{Introdução}

\section{I.1. Do tema e do problema}

O tema desta Tese é a interpretação dos sonhos no tratado hipocrático Da dieta, como uma espécie de conhecimento do corpo. Trata-se de uma forma de mapeamento das perturbações do corpo que não são evidentes a uma mera observação diagnóstica e que serve como um tipo específico de prognose para a manutenção da saúde. Esse

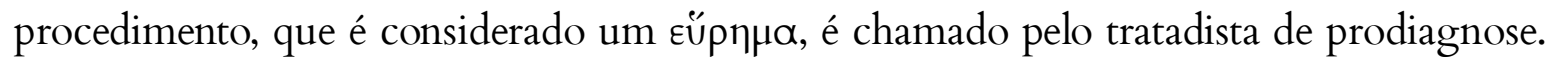

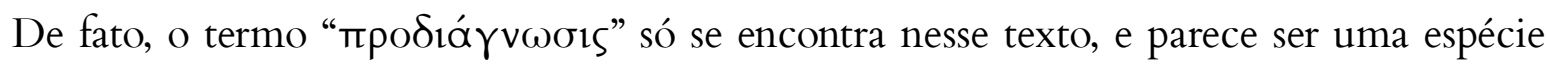
de neologismo do nosso autor, coincidindo com o caráter inovador que é próprio de um

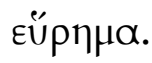

A prodiagnose depende, assim, do material apresentado pelos sonhos, que são um produto exclusivo da alma, que, por sua vez, possui atividade plena enquanto o corpo dorme. Ela, enquanto "dona da casa", por si, realiza todas as atividades que o corpo

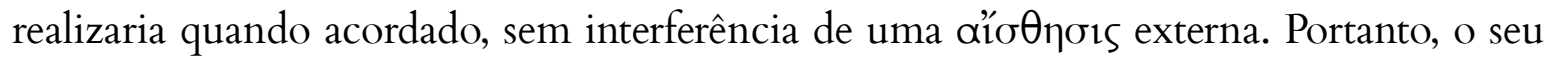
conhecimento é fruto de um saber que nela está assentado: esse conhecimento parece ser

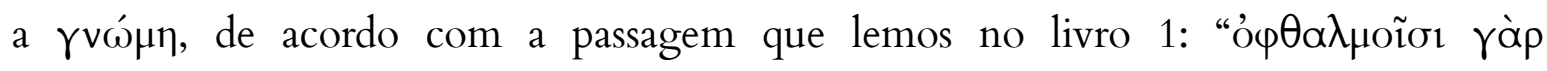

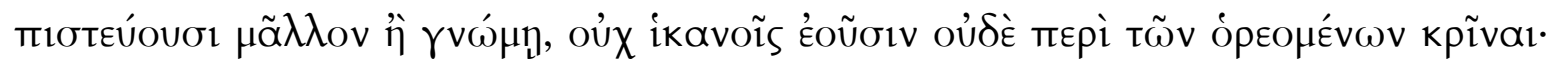

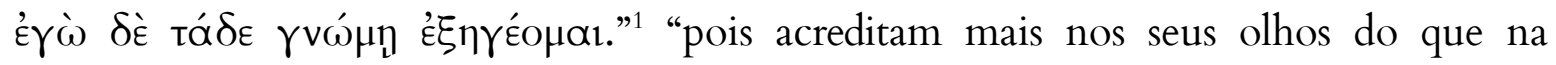
$\gamma \vee \omega ́ \mu \eta$, não sendo capazes de discernir nada dentre as coisas visíveis. Eu, no entanto, estas coisas explico a partir da $\gamma v \omega ́ \mu \eta . ”$

O conhecimento e reconhecimento dos sonhos enquanto material da prodiagnose depende da compreensão do processo de conformação do corpo e da alma, que ocorre

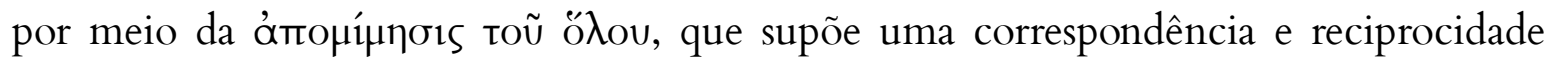

\footnotetext{
${ }^{1}$ Da dieta 1,4
} 
entre a esfera macrocósmica relativa aos elementos de uma parte da púors que é imutável (as esferas celestes são o maior exemplo disso) e a microcósmica, relativa ao corpo, que, por sua vez possui elementos da púoıs passíveis de modificação (como exemplo, o movimento de rotação da alma, que interfere na formação dos tipos de inteligência, que podem ser melhorados ou piorados por meio da dieta).

O que se impõe como questão aqui é a forma como, segundo o tratado, essa relação da alma com o corpo se estabelece no sonho e como funciona essa representação anímica do ó入ov.

Está fora do escopo do tratado uma análise do sonho como um todo, ao modo de Aristóteles nas obras que tratam dos sonhos. O Livro IV tem, por matéria de sua

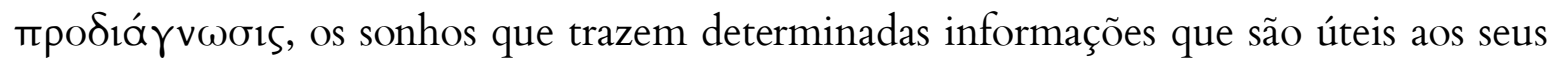
propósitos (sonhos com os atros, com as ações diurnas, com elementos ligados ao $\tilde{\eta} \theta$ os, com elementos ligados à púoıs, com mortos, com monstros ou imagens hostis, com hoplitas, com desejos do apetite). A lista não é extensa, mas é precisa. Muitos sonhos não se incluem aí, e o tratadista deixa claro que esses sonhos são temas dos outros que os interpretem pela $\tau$ tÉ $\chi \vee \eta$.

Aqueles sonhos arrolados pelo tratado, contudo, são os que fornecem dados para uma semiologia médica. Mas a semiologia médica que se encontra nos demais tratados do Corpus hippocraticum sustenta-se sobre os pilares dos ońfata oriundos ou da

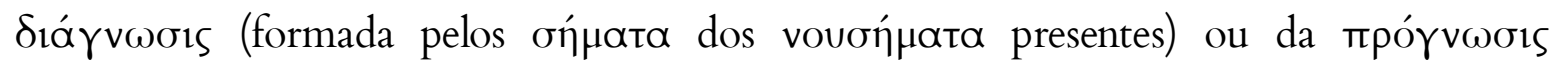
(formada pelos ớ ${ }^{\prime} \alpha \tau \alpha$ das voũooı vindouras). Os sonhos, porém, não têm lugar ali. Nem falam a respeito de eventos do presente nem do futuro (tampouco do passado) de um indivíduo ou coletividade, mas expressam um conjunto de ớfata que exigem uma semiologia própria, porque revelam, por meio de sinais muito singulares, algo que não vai bem no corpo e que pode redundar em doença visível ou invisível.

Esses sinais são decodificados por sistemas de analogia que partem do princípio de que a púors do corpo comunga da púors maior, mas como parte reduzida, 
semelhante e autônoma. Em outras palavras, é um microcosmo que reproduz as estruturas do macrocosmo, ao mesmo tempo integrando-o e sendo dele independente.

O metódo analógico é, portanto, próprio da $\pi \rho 0 \delta i o ́ \gamma v \omega \sigma 1 \varsigma$, mas não está respaldado em uma associação arbitrária, senão obedece a um critério de correspondência entre o micro e o macrocosmo, que partilham a mesma natureza. Tal correspondência trafega por muitos escritos legados pela Antiguidade grega, e tais testemunhos, se são fundamentais para a compreensão desses elos, não resultam na construção de um quadro de prodiagnose.

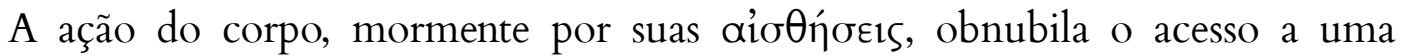
informação preciosa e verdadeira e que clama por uma hermenêutica apropriada. Essas informações são transmitidas pela alma livre das sensações ${ }^{2}$ e que absorvem o mundo que lhes é externo por meio de passagens (de rópol), pelas quais também projeta as imagens que gesta a partir das informações captadas, processadas pelos mecanismos que reproduzem, em escala pessoal, o funcionamento cíclico da púors.

Numa perspectiva pitagórica do ciclo perfeito, o tratado propõe a ideia de

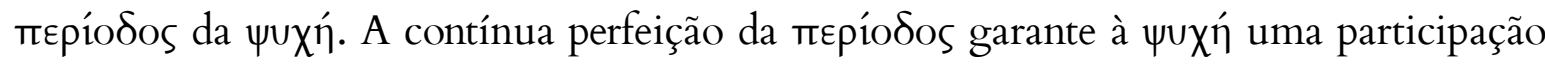
plena, portanto saudável, em uma púors em que está inserida. Efetivamente, ressoam, nesse princípio, as palavras de Alcmeon de Crotona, para quem, como registra um Pseudo-Aristóteles (Problema XVII, 916a 33 = Alcmeon, B 2DK), as pessoas só morrem porque não conseguem unir o fim ao começo.

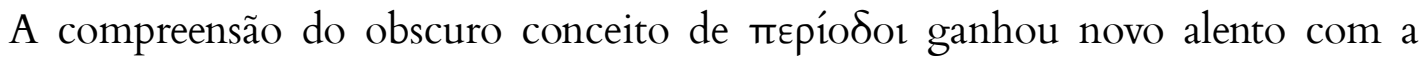
contribuição de Jacques Jouanna (2012), que apontou a relevância e a pertinência da

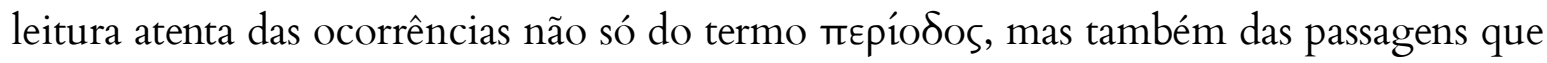
envolvem esse "circuito da alma" no Timeu de Platão.

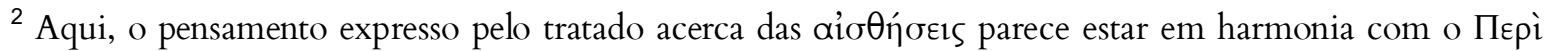

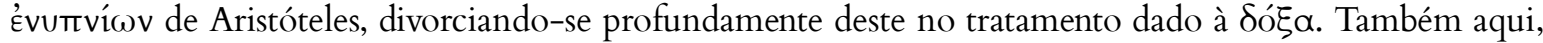
sobre lugar das aio $\theta \dot{j} \sigma \in ı$ s poder-se-ia notar algo relacionado ao dolo dos vontó em Platão (por exemplo, no final do livro sexto da República). Jouanna, contudo, em uma longa explanação acerca do fato de

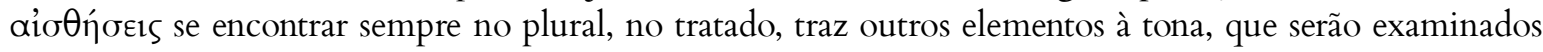
adiante.
} 


\section{I.2. Do corpus}

O tratado Da dieta é o mais plural em temas em todo o Corpus hippocraticum, e, apesar disso, curiosamente o assunto menos abordado é a doença. Esse longo tratado está dividido em quatro livros, e o corpus desta Tese é o quarto destes, que versa exclusivamente sobre o papel do sonho na medicina, especialmente como campo

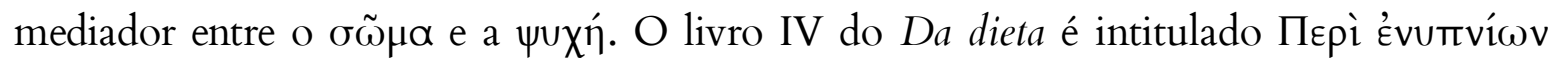
pelo menos desde o século XV (Parisinus 7337, em suas páginas 170-173), e parece ter sido no século seguinte, mais precisamente em 1557, que esse título ganhou notoriedade, pela histórica edição de Guillaume Morel, em latim (Hippocratis aphorismorum libri, prognostica, coacae praenotiones, prorrheticorum libri, de insomniis, jusjurandum). Nesse momento, aliás, o livro IV não consagra apenas seu titulo, como também sua pouco razoável autonomia em relação aos outros três livros do Da dieta. Émile Littré, em sua histórica edição, no sexto dos dez volumes do Corpus hippocraticum, publica o livro IV com o título alternativo de Пepì Évurvíwv (Livre quartième ou Des songes).

No entanto, o Livro IV do Da dieta parece não ter tido nenhuma autonomia na Antiguidade. Galeno de Pérgamo, o mais ilustre comentador de Hipócrates conheceu o tratado Da dieta com apenas três livros, e acompanhando o tratado de título $A$ natureza do homem e a dieta para a saúde. Certamente, o manuscrito conhecido por Galeno não era exatamente o mesmo que veio a ser base das edições modernas. O quarto livro foi editado como tal apenas no século XIX, na edição de Émile Littré, que se inspirou na tradição legada pelo manuscrito Marcianus gr. 269, datado do X século, que já o considerava parte independente do terceiro livro.

O Da dieta é um dos poucos tratados do Corpus hippocraticum pautados pela ideia de saúde. Todos os elementos do tratado apontam para uma normalidade, o que quer 
dizer que a doença não se inscreve no seu escopo. Esse tratado, em muitos aspectos único, pode se alinhar, todavia, a outros, a partir do ponto de vista de que todas as prescrições pretendem antecipar-se a um estado de anomia, e pode ser colocado ao lado de tratados tais como o Prognóstico, ou Da natureza do homem, que se inserem no campo de uma lida com a púørs a partir de uma ideia de equilíbrio dos elementos do vó sem considerar a anomia, ou, em outras palavras, o ambiente patológico. Por outro lado, pelo seu caráter cosmológico, irmana-se a textos que estão fora do campo da medicina, a saber, uma vasta produção de Hesíodo aos physiológoi, muitas vezes ecoando suas doutrinas, a modo de diálogo, atrelando aos elementos primordiais de uma púors as

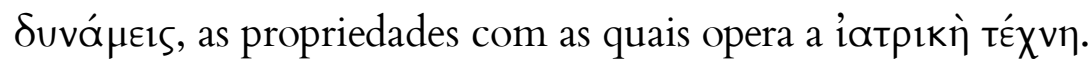

O tratado Da dieta apresenta diversas singularidades em relação ao conteúdo, e tais peculiaridades destacam seu lugar no Corpus hippocraticum. Esse seu caráter gerou certa aura que lhe garantiu um interesse especial ao longo de vários séculos, e sua leitura - como um autêntico vade-mecum - rendeu-lhe uma apropriação no campo da medicina que, a partir dele constituiu o que Joly diz ter sido a 'verdadeira' ${ }^{\text {'3 }}$ dietética como se a conheceu até o século XIX ${ }^{4}$.

De fato, há notas testemunhais que o inserem numa suposta tradição de catálogos dietéticos morais, atribuída à doutrina pitagórica. "Suposta tradição de catálogos", pois, de fato, não existe registro algum que tenha chegado a nós, mas apenas testemunhos ${ }^{5}$. De todos, esse foi precisamente o único sobrevivente. Especulando a respeito disso, atrevo-me a pensar que foi a inserção no campo da medicina hipocrática, enquanto prática escrita, que permitiu a sua permanência.

\footnotetext{
${ }^{3}$ Joly (Le niveau de la science hippocratique, 1967, p.122) mostra com riqueza argumentativa a importância dessa dieta "verdadeira".

${ }^{4} \mathrm{O}$ século XIX produz uma passagem do Corpus hippocraticum da medicina para a história da medicina (CAIRUS, 2000, p.5-7)

${ }^{5}$ Cf. Joly \& Byl, 1984, p.20
} 
Jacques Jouanna, um dos principais nomes nos estudos do Corpus hippocraticum da atualidade e estabelecedor dos textos da Coleção Hipocrática pela Editora Les Belles Lettres, apresenta, na sua obra de referência Hippocrate (1992, p.557), um resumo bastante acurado e sucinto do tratado Da dieta:

O tratado hipocrático Da dieta se divide em 4 livros. No primeiro, o autor dedica seus parágrafos a expor sua cosmologia, uma vez que considera que é essencial para prescrever uma dieta conhecer a natureza do homem. O homem, como os outros seres vivos, é constituído de duas substâncias primordiais, o fogo e a água, indissociáveis e complementárias. O fogo, quente e seco, tem por propriedade mover; a água, fria e úmida, tem por propriedade nutrir, mas as mudanças se operam entre esses dois elementos a partir das misturas, o que explica a diversidade dos seres vivos. O nascimento é a reunião desses elementos, e a morte, a separação. $\mathrm{O}$ autor trata em seguida da formação da natureza humana numa longa exposição de embriogênese. Expõe notadamente como o fogo organiza o embrião à imitação do universo ao criar três circuitos no interior do corpo, que são a imagem das revoluções da lua, do sol e dos astros (caps. 9-10). Tal organização da púoıs

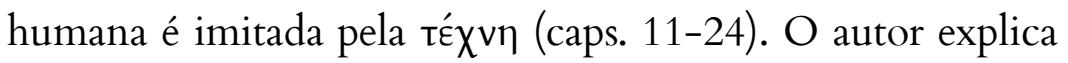
a formação do embrião macho ou fêmea (pela reunião de duas sementes vindas respectivamente do homem e da mulher), dos gêmeos e a superfetação (caps. 25-31). Expõe os diferentes tipos de constituições corporais e de 
inteligência de acordo com as variedades de mistura de água e fogo (caps. 32-36)

Sobre os catálogos de alimentos e exercícios contidos no livro II, dos capítulos 37-66, e no livro III, dos caps. 67-85, Jouanna segue o seu resumo:

É essencialmente um catálogo das propriedades naturais e artificiais dos elementos da dieta (alimentos, bebidas e exercícios); é o mais desenvolvido catálogo da Coleção. Está precedido de dois capítulos sobre a influência dos lugares e dos ventos.

O terceiro livro (caps. 67-85 nas edições; cap. 67 até o fim em Galeno e em outros manuscritos antigos) trata de uma dieta propriamente dita. O ideal, segundo o autor, seria chegar a um equilíbrio exato entre alimentos e exercícios. Mas as demasiadas variantes muitas vezes impedem a realização de tal equilíbrio. $\mathrm{O}$ autor distingue dois públicos: os que trabalham e não podem ocupar-se da sua saúde, e aqueles que dispõem de ócio para pensar na sua saúde. A respeito dos primeiros, expõe uma dieta anual em função de cada estação; mas se refere sobretudo a uma elite e revela o que ele acredita ser a sua descoberta. Tal descoberta é um prognóstico prévio à doença e um diagnóstico da causa que acarreta sempre um desequilíbrio entre os alimentos e os exercícios. Ilustra sua descoberta por uma série de casos (cap. 70-85): seis para os alimentos sobre os exercícios e oito para os exercícios sobre os alimentos. 
A respeito do livro IV, que constitui o corpus desta Tese e cujo tema aqui procuro expandir mais à frente, assim o resume:

O quarto livro (cap. 86-93, apenas nas edições modernas) completa a exposição do diagnóstico prévio para a utilização dos sonhos. O autor distingue duas categorias de sonhos: os divinos, que anunciam fortuna ou infortúnio e sejam úteis aos intérpretes de sonhos; os sonhos em que a alma informa sobre o estado do corpo e que são competência dos médicos. A respeito da segunda categoria, o autor estabelece um prognóstico e um diagnóstico sobre a saúde e a doença em função da diferentes visões. Aconselha eventualmente um tratamento. É nesse quadro que ele recomenda preces aos deuses.

Para além da cosmologia presente no Da dieta, insere-se o escrito numa tradição catalográfica da qual temos vago resquício, mas que o testemunho do próprio tratado faz crer que gozavam de certa popularidade na segunda metade do século $\mathrm{V}^{6}$. Esta tradição à qual o autor do tratado a ser estudado se refere como incompleta ${ }^{7}$, ganha, através da sua inserção na tradição hipocrática, o caráter de prescrição com vistas à saúde

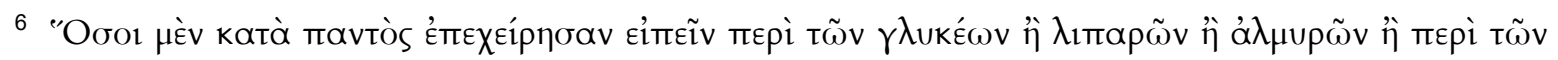

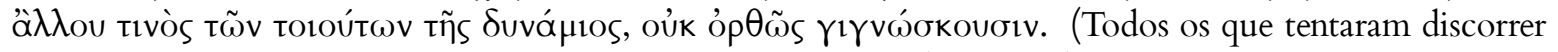

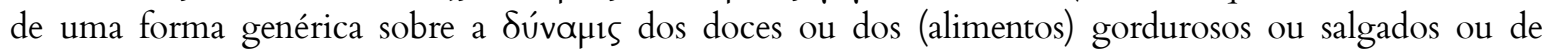
qualquer outro (alimento) assim, não os conhecem corretamente. 39Littré). Observe-se aqui o uso do termo öбol, que sugere haver uma certa quantidade de discursos em forma de catálogos alimentícios, mas, ao menos segundo o autor estudado, esses discursos eram katà ravtós, genéricos. O uso desta expressão insinua que, ao contrário daquele do Da dieta, os demais catálogos não contemplam um fim específico, e, por isso, não seriam da ordem da té \} \vee \eta \text { . }

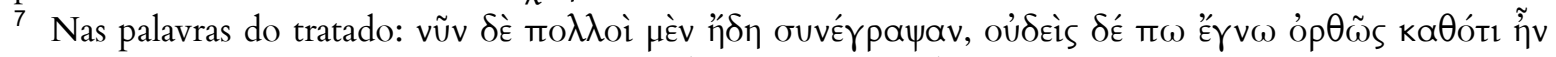

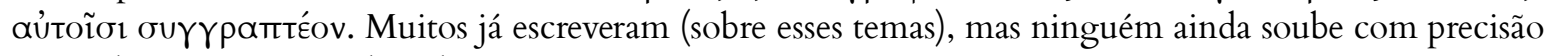
como deveria escrever sobre eles. 
aparentemente sem um caráter estritamente moral $^{8}$, como se diz terem sido os catálogos pitagóricos de alimentos, propondo-se ele mesmo, bem ao modo de outros tratados hipocráticos ${ }^{9}$, fazer uma síntese superior aos seus precedentes:

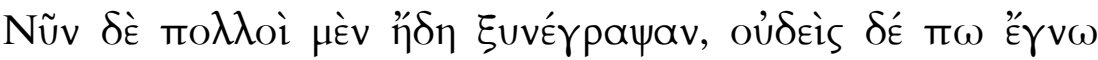

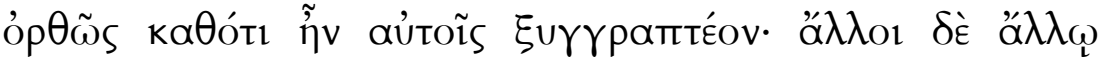

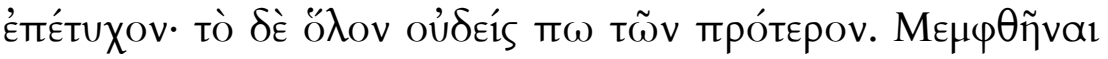

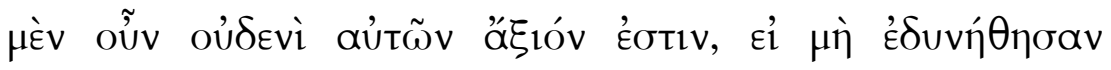

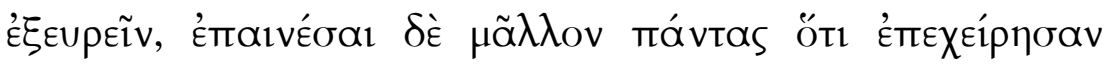

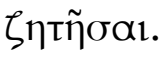

Muitos já escreveram (sobre esses temas), mas ninguém ainda soube com precisão como deveria escrever sobre eles. Alguns acertaram num ponto, outros em outro; mas no todo ainda nenhum dos meus predecessores o fez. Entretanto, não é justo condená-los por não haver podido completar suas descobertas, mas é preciso elogiá-los por haver empreendido tal investigação.

Para além do gênero de escrita - o da छurrpapń -, que abarcava tratados de cunho filosófico ou pragmático como o Da dieta, o fato de o nosso autor insistir na

8 Registre-se aqui que uma perspectiva tradicional, que tem por grande baluarte o polígrafo Laín Entralgo, caminha na direção diversa à que propomos, e encontra feições morais e até religiosas nas dietas pré-hipocráticas, conferindo, assim, como sói acontecer a esse tipo de abordagem, um papel laicizador à escola hipocrática. Tal abordagem, além de estar comprometida com uma perspectiva evolucionista, nega ao Corpus hippocraticum seu aspecto dialogístico em relação a cultura que o cerca e que, em certa medida, o engendra. Apesar disso, esta Tese não negligencia o papel que os estudos dessa ordem desempenharam na construção da imagem de um Hipócrates pai não somente da medicina, mas de toda a ciência, como tanto queria Émile Littré.

${ }^{9}$ Em especial, o Da medicina antiga. 


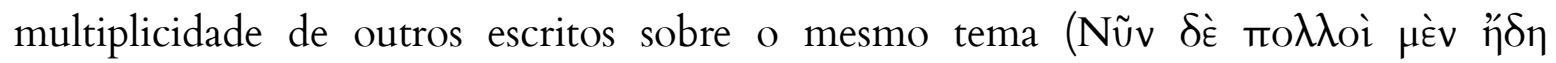

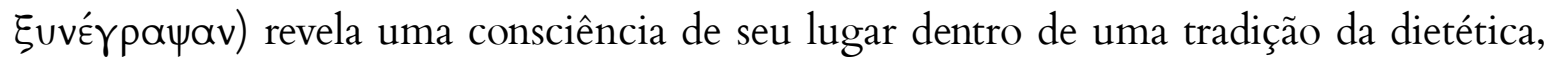
assim como dentro das próprias práticas da medicina hipocrática, que se consolidava naquela época principalmente através da transmissão escrita ${ }^{10}$. De acordo com Loraux ${ }^{11}$,

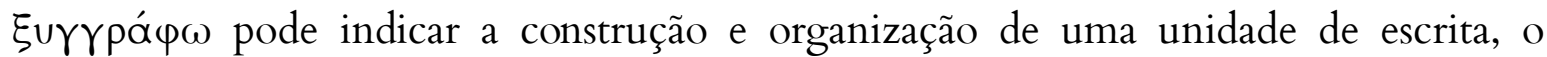
próprio objeto e a própria escrita. Segundo Bakker ${ }^{12}$ :

The referentiality of the technical manuals of the time, which were called syngraphai, shares in this kind of writing: their writer rearranges and systematizes previous practice in order to facilitate subsequent practice, and so writes the art's envisaged érgon.

Semanticamente, a escrita do nosso autor não é a mesma que a dos ro $\lambda \lambda \lambda_{\text {oí a }}$ quem se refere, e a diferença reside nos modificadores do verbo. O modificador a que me refiro é o conhecimento que o autor do texto se propõe a escrever: trata-se de um ỏ $\theta \theta \tilde{s}$

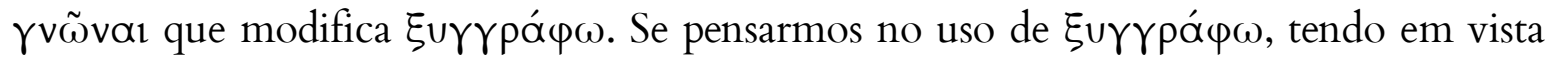
o projeto do tratado como um todo, percebemos haver uma certa teleologia no uso desse "conhecer corretamente": por um lado, é ele quem permite o escrever, a partir da negação dos outros, e é, por outro lado, ele o próprio resultado da छurrpapŕ.

Para além da literatura hipocrática, a dieta era compreendida como uma inovação, associada a uma nova ordem políade. Aristófanes, na comédia As nuvens (960-84), no ả $\gamma \omega ́ v$ entre o Raciocínio Justo e o Raciocínio Injusto, menciona as práticas dietéticas,

10 Conforme aponta I.M. LONIE, no artigo "Literacy and the development of Hippocratic Medicine". In.: Formes de pensée dans la Collection Hippocratique. Genève: 1983, pp.145-61.

${ }^{11}$ Loraux, N. "Thucydide a écrit la Guerre du Péloponnèse", Métis, v.1, n.1, 1986, p.145. "Xyngraphô: rassembler par êcrit, constituer une unité de discourse historique. (...) Xyngraphô, donc: façon thucydidienne de désigner l'écrire historique em tant qu'il organise les évenements en une totalité."

12 BAKKER, E. "Contract and Design: Thucydides' Writing” In: TSAKMAKIS A.; RENGAKOS A. (Eds.) Brill's Companion to Thucydides. Leiden: Brill, 2006. pp. 109-129 
referidas, em significante metafórico, pelo Raciocínio Justo, que, por sua vez, opunha-se à atmosfera de novidade da pólis. Trata-se de uma inversão que parece ressaltar o contraste entre a dieta alimentar característica da proposta de uma nova ordem e os costumes pudicos que o Raciocínio Justo reivindicava. Defendemos que a ideia era usar as armas do rival retórico, transformando-as em metáforas que trazem à cena uma saudosa ${ }^{13}$ pudicícia relacionada às manifestações públicas dos desejos sexuais. De qualquer maneira, a dieta é explicitamente citada, numa referência à prescrição (e interdição) dos rabanetes - que, por sua vez, são imagens evidentemente fálicas -, dando razões para se pensar em uma certa popularidade desse tratado, e, até mesmo, numa possível resistência a ele (973-83):

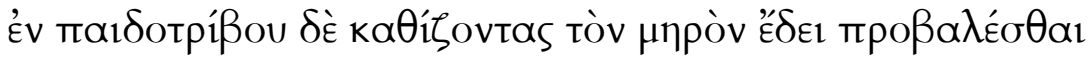

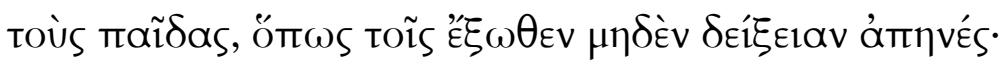

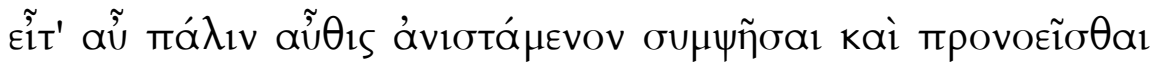
975

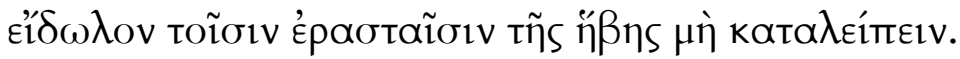
(...)

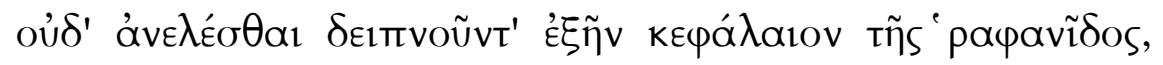
981

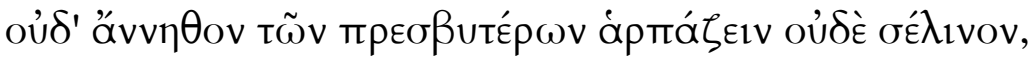

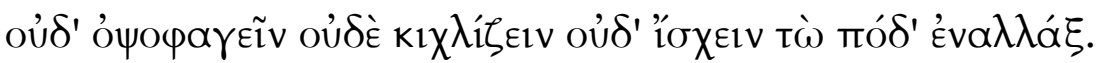

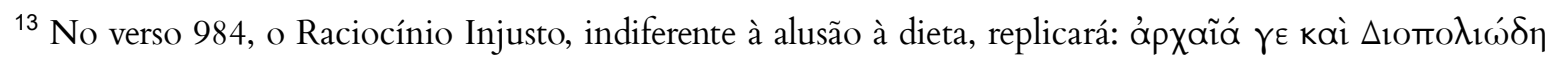

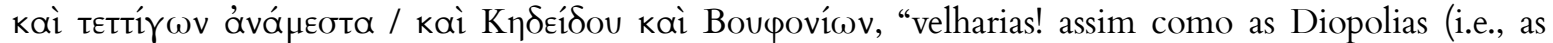
festividades de Zeus padroeiro), plenas de cigarras, / de Cidides (i.e., dos ditirambos antigos de Cidides) e de bufonias (i.e., de sacrifícios de bois, em pleno desuso)". Seguimos aqui a sugestão do LSJ e interpretamos a expressão "plenas de cigarras" como "plenas de prendedores de cabelo antiquados". Tais prendedores foram usados nas Guerras Greco-Pérsicas, conforme atesta Tucídides em sua Arqueologia (1.6). A réplica insiste no tópos do novo contra o antigo, mas sua posição evidencia a postura saudosista do adversário, o Raciocínio Justo.
} 
E nas aulas de ginástica, os jovens deviam sentar-se com as pernas esticadas, de modo que aos de fora nada deixassem ver; e depois ao se levantarem novamente deviam todos juntos varrer o chão e evitar mostrar uma imagem de virilidade aos admiradores.

não era permitido ao jantar (comer) a cabeça do rabanete, nem pegar no aneto nem no aipo dos mais velhos, nem comer peixes nem gargalhar nem manter as pernas cruzadas.

E ainda nos versos 999-1000 há uma jocosa referência a Hipócrates, filho de Arrifron e, portanto, primo de Péricles, cujos três filhos eram conhecidos pela sua proverbial estupidez. A homonímia com o célebre médico parece reforçar a hipótese da referência à dieta em versos não anteriores e próximos. Nesses versos, o Raciocínio Injusto inverte o jogo, acusando o adversário de unir-se a quem deveria ser identificado como associado às ideias novas:

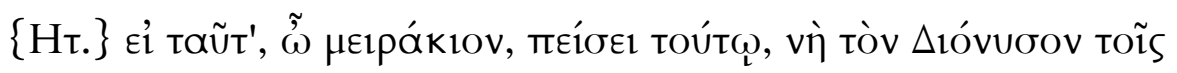

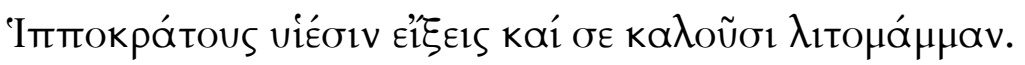

Se dessa forma, menininho, com isso sofres, por Dioniso, parecerte-ás com os filhotes ${ }^{14}$ de Hipócrates e chamar-te-ão de grande mamador de tetas ${ }^{15}$.

\footnotetext{
${ }^{14}$ Jogo de palavras intraduzível, uma vez que viı́ơıv (dat. pl. de viós) é quase homófono de ướv (dat. pl. de ús, "porco", animal que os gregos frequentemente associavam à estupidez (ver Ar. Pax 928; Eq. 986).

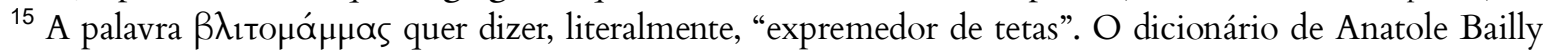
apresenta a tradução "grande tolo" para esse vocábulo, o que, a nosso ver, tem uma carga pejorativa muito menor do que a que o texto sugere. Nossa hipótese é a de que, nessa passagem, o Raciocínio Injusto faz ressoar a ideia de que seguir Hipócrates (mamar-lhe às tetas) é uma grande estultícia pueril, fazendo ecoar esse nome que, ao mesmo tempo é ligado à família de Péricles e ao célebre médico, valendo-se, assim, de um sofisticado recurso que, ao mesmo tempo, traz a lembrança do emblemático nome de Hipócrates e
} 
Jouanna, ao introduzir o capítulo que trata da terapêutica dietética, tece uma observação na qual invoca outros testemunhos ${ }^{16}$ :

\begin{abstract}
Além dos registros de cuidados que precisam de uma terapêutica de intervenção (medicamentos catárticos, incisões, cauterização), o médico dispunha de um registro para se opor à doença: a dieta do doente.
\end{abstract}

Assim, a terapêutica de intervenção pertence à medicina tradicional, a arte da dieta passa da antiguidade para ser uma conquista mais recente. $O$ testemunho mais célebre a esse respeito é o de Platão, na República (407d-408b):

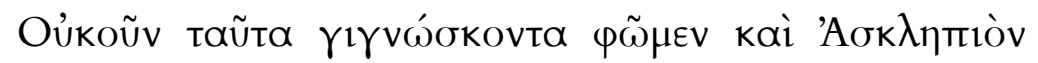

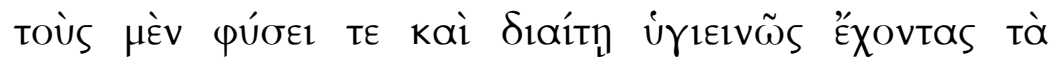

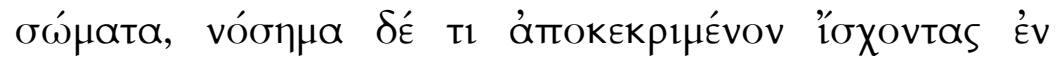

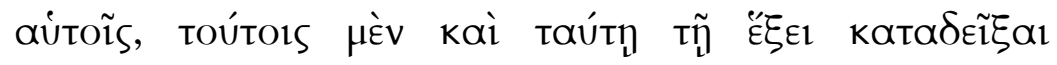

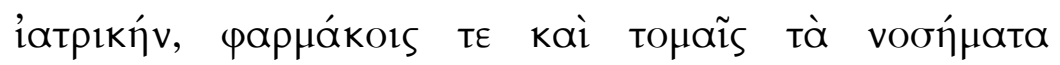

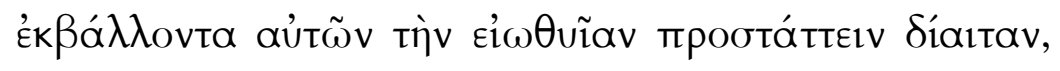

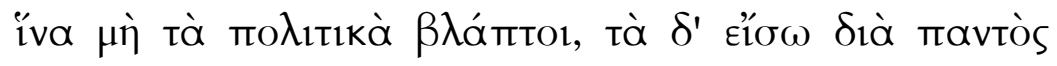

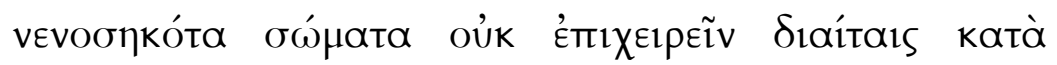

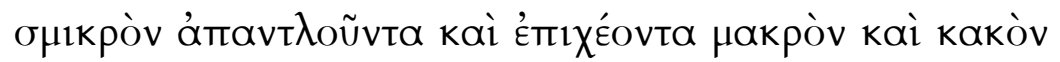

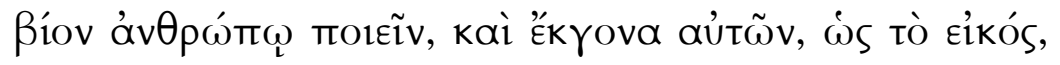

coloca-o ao lado de seu adversário, sugerindo uma identificação entre o Raciocínio Injusto e uma visão ingênua daquilo que era tomado como novidade.

16 1992, p. 232-3. 


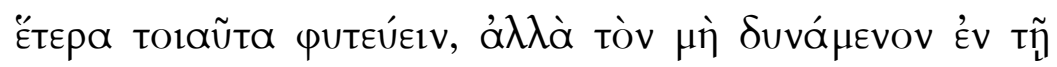

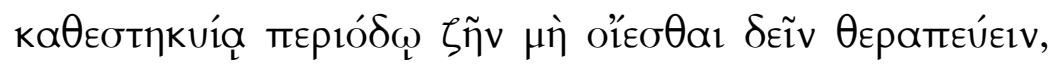

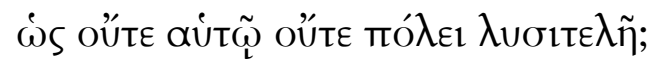

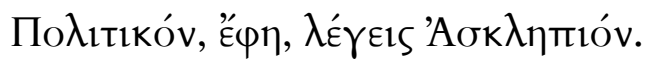

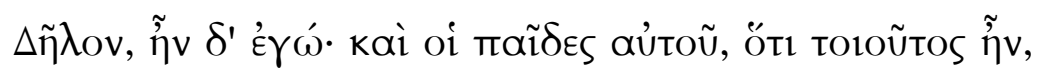

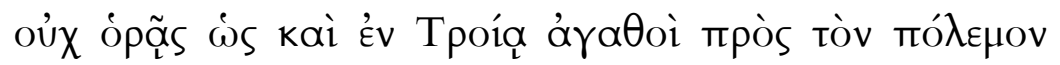

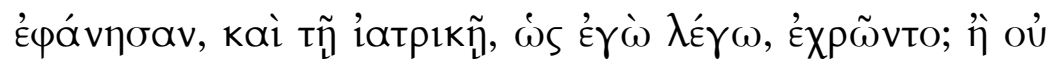

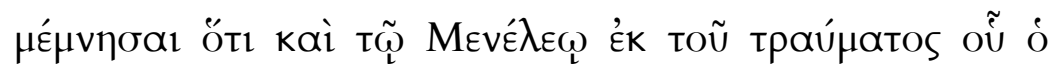

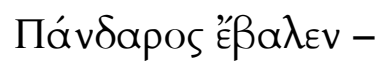

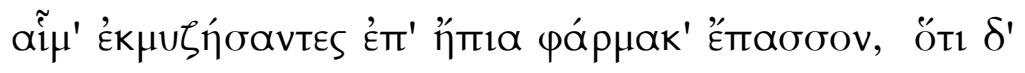

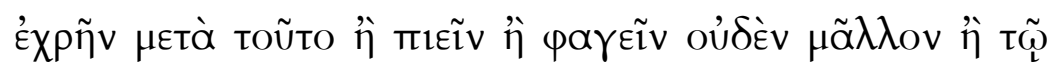

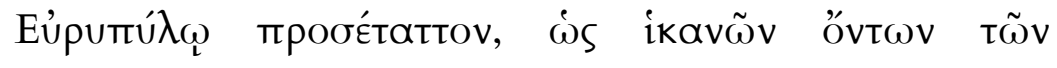

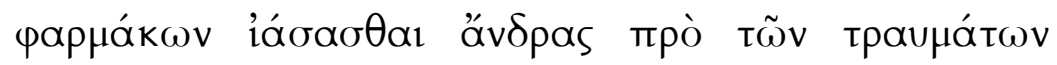

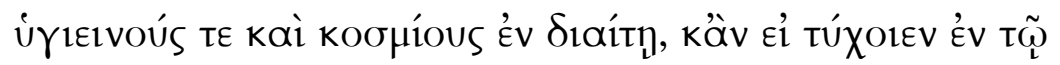

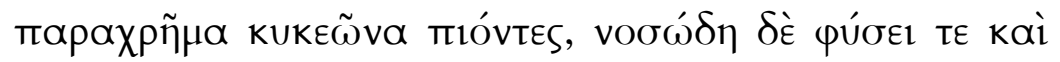

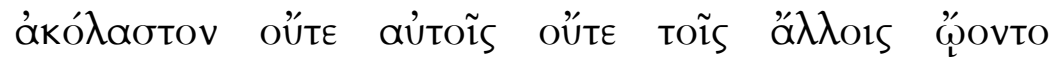

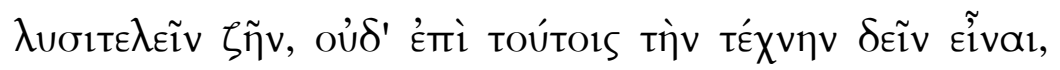

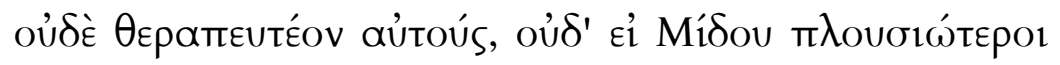
عĩ $\varepsilon$.

- Por conseguinte afirmaremos que também Asclépios sabia isto, e que, para os que gozam de saúde física, graças à sua natureza e à sua dieta, mas têm qualquer doença localizada, para os que têm essa constituição, ensinou a medicina, que expulsa as suas enfermidades por meio de remédios e incisões, prescrevendo-lhes a dieta a que estão habituados, a fim de não prejudicarem os negócios políticos. Quanto aos corpos todos minados pela doença, não tentou, sujeitandoos a um tratamento paulatino de infusões e purgas, tornar a 
vida desses homens longa e dolorosa, nem que gerassem filhos semelhantes a eles, como é natural; mas àquele que é incapaz de viver no círculo de ação que the foi adstrito, entendia que não se devia aplicar terapêutica, uma vez que nada lucrava com isso, nem o próprio, nem o Estado.

- O Asclépios de que falas é um político - objetou ele.

- É evidente - confirmei eu -. E os filhos, porque ele era assim, não vês como em Troia se mostraram valentes no combate e praticavam a medicina, como digo? Ou não te lembras do que eles fizeram a Menelau, quando, do ferimento que Pândaro lhe fez ao atingi-lo, - chuparam o sangue, espalhando por cima mezinhas calmantes - e não lhe prescreveram o que havia de beber ou de comer depois, como não o haviam feito a Eurípilo, entendendo que os remédios eram suficientes para curar homens que, antes de serem feridos, eram saudáveis e de regime moderado, embora se desse o caso de naquele momento terem tomado a poção; ao passo que para os enfermiços por natureza e libertinos, entendiam que não thes aproveitava viver, nem para eles nem para os outros, e que não valia a pena para eles existir a arte de curar nem trata-los, ainda que fossem mais ricos do que Midas. ${ }^{17}$

Para Jouanna (1992), à medicina farmacológica da época de Homero se opõe a medicina dietética dos seus contemporâneos. Platão, no entanto, não via nessa evolução um progresso. Essa nova medicina, que constrangia os doentes a uma observação de um

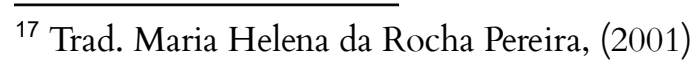


longo regime, os desviava, segundo ele, de cumprir seus deveres de cidadãos. Mas, vista do lado dos médicos, tal evolução apareceu como um progresso. $\mathrm{O}$ autor hipocrático que expôs a dieta para as doenças agudas critica o caráter farmacológico da terapêutica dos autores das sentenças cnídias e reprocha os antigos em geral de não haver dito nada válido sobre a dieta. Uma terapêutica que não se contenta com um catártico, com uma incisão ou com uma cauterização para evacuar o mal, mas que adapta a dieta do doente à doença e à sua evolução, eis algo que passou por uma novidade da medicina do fim do $\mathrm{V}$ e início do IV, já mesmo aos olhos dos contemporâneos.

Trata-se aqui, portanto, de uma pretensa parte do grande mosaico do discurso civilizatório no qual os gregos da pólis clássica, em vários momentos, se empenhavam e ao qual aprenderam a opôr uma ancestralidade que Tucídides $(1.6)^{18}$ chegou a identificar com os mesmos bárbaros retoricamente irmanados em uma não (ou sub) cultura, a despeito do trabalho de Heródoto e do autor do tratado Ares, águas e lugares ${ }^{19}$. Consiste pressuposto fundamental desse projeto civilizador a abrangência do conceito de vóros, que merece ser repensado para além da alçada do binômio, já clássico na teoria, formado pelos conceitos de natureza e cultura. O vó interessa-nos para entender o procedimento hipocrático, uma vez que as operações dietéticas eram circunscritas a esse limite, a partir do qual sua prescrição dialogava com a púors. Lê-se no primeiro livro do Da dieta (69):

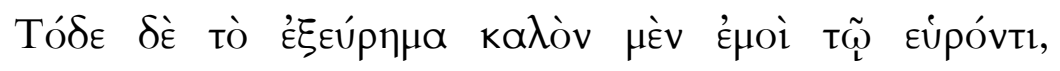

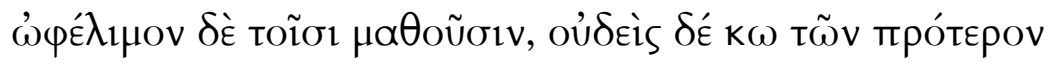

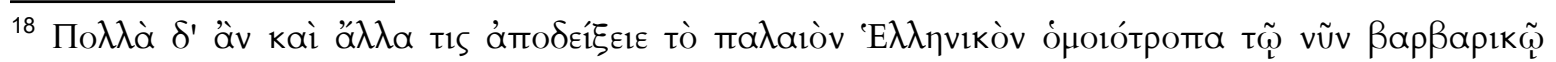
$\delta ı \alpha \iota \omega ́ \mu \varepsilon v o v$, "em muitas coisas poder-se-ia demonstrar que os antigos gregos tinham uma dieta

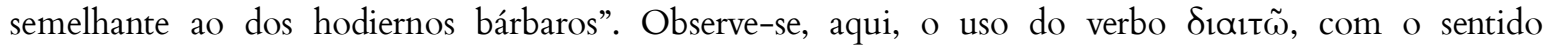
mencionado no início deste artigo, o de "conduzir deliberadamente a vida".

${ }^{19} \mathrm{~A}$ esse respeito, ver H.F. CAIRUS, Asiáticos diferentes entre si: o Corpus hippocraticum e a alteridade interna, Rio de Janeiro, PROAERA, 2003, disponível em http://www.letras.ufrj.br/proaera/ alteridadeinterna.pdf.
} 


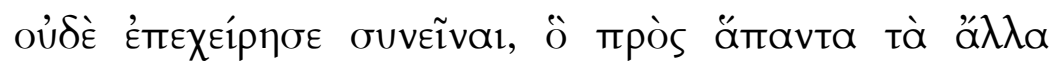

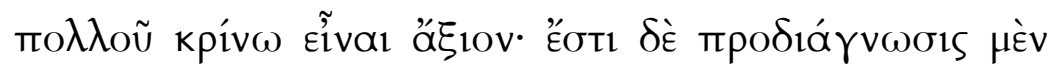

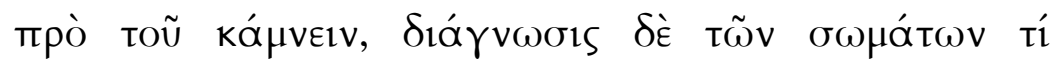

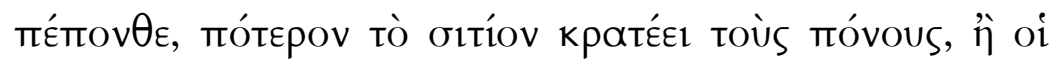

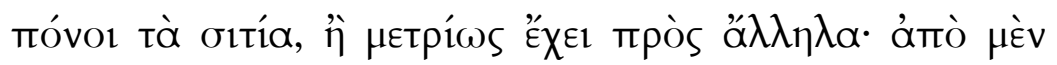

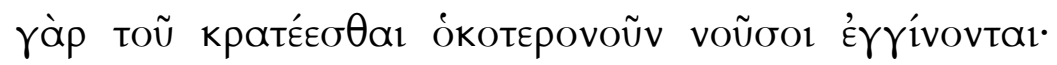

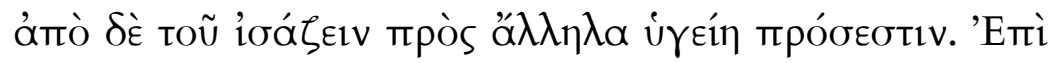

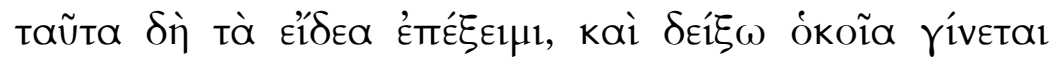

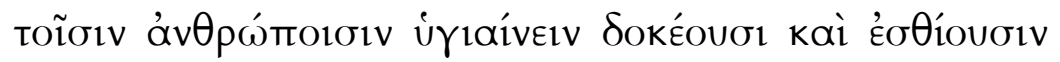

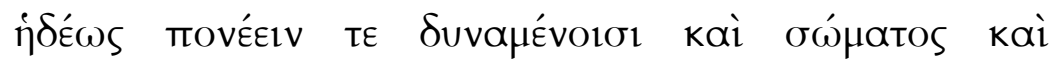

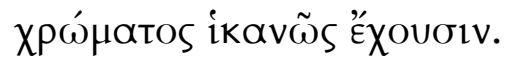

Este descobrimento é belo para mim, que o descobri, e útil para os que aprendem, pois nenhum dos que antes tentaram englobar alguma coisa, o que, frente a todas as outras coisas, julgo ser de muito valor. É a prodiagnose antes de adoecer, a diagnose, dentre os corpos, o que ocorre, seja o domínio do alimento sobre os exercícios, ou dos exercícios sobre o alimento, ou do equilíbrio entre ambos. Pois do domínio de qualquer um ocorrem as doenças. E do equilíbrio entre eles provém a saúde. Então, a partir destas ideias explico em detalhe e mostrarei como é para os homens que julgam estar saudáveis e comem com prazer e se exercitam como podem, e são suficientes de corpo e de cor.

A prodiagnose desse autor se esquematiza numa base positiva pautada no conceito de saúde. Isso fica evidente quando, na descrição das $\delta$ vó́ $\mu 1 є \varsigma$ dos alimentos e 
exercícios, o ponto central é o efeito que a combinação tem no homem saudável, e considera apenas desequilíbrios da ordem dos sintomas leves (para citar alguns, diarreias, azias, disúrias, febres brandas, corizas e insônia), prévios à doença. Nesse sentido, a doença ficaria situada além do ponto extremo do seu esquema fechado, reafirmando o caráter higiênico da sua obra. Já a dieta dos doentes ocupa o centro dos tratados Das afeç̧ões e Da dieta nas doenças agudas e também em Epidemias, o que reitera o caráter da obra.

O tratado Da dieta considera fundamental a tensão e complementação entre os opostos, cujo maior exemplo talvez seja a dicotomia formada por vónos e qúors, que, à primeira vista, parece remeter a um argumento de boa tessitura retórica de uma oposição entre humano e divino:

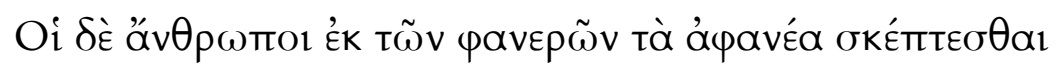

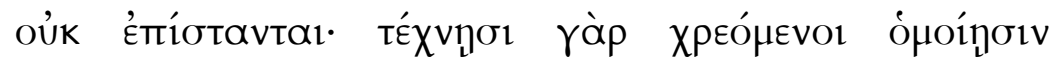

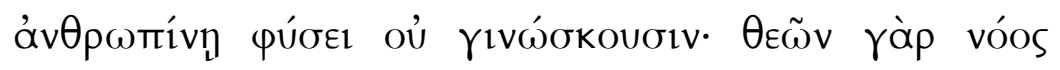

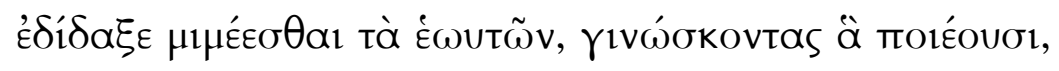

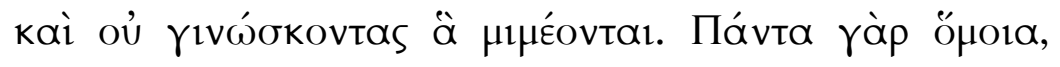

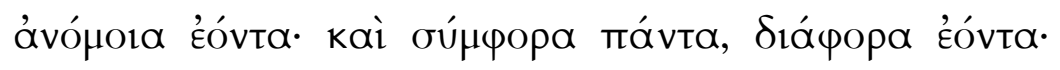

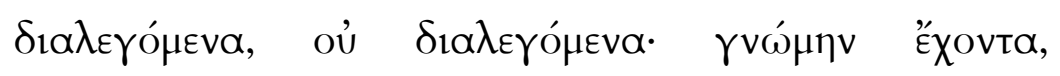

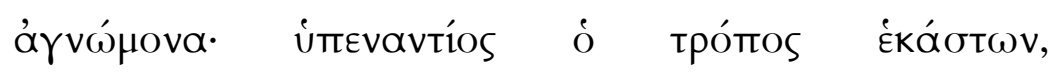

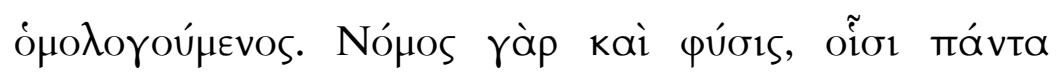

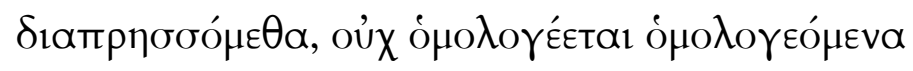

Os homens não sabem observar o invisível a partir do visível. Pois utilizando tékhnai semelhantes à púors humana, não o sabem. Pois o pensamento dos deuses ensinou a imitar o que lhes é próprio, e, conhecendo o que fazem, não conhecem o que imitam. Pois tudo é 
semelhante sendo dissemelhante, concorda não concordando, possui razão, não tendo razão. Oposta é a direção de cada uma das coisas, completando-se entre si. Pois vónos e qúoıs, através dos quais obtemos tudo, não concordam concordando. (De dieta, 1, 11)

O Da dieta faz parte dos tratados hipocráticos nos quais se nota com clareza irrefutável a instrumentalização do saber retórico. O capítulo quarto do primeiro livro do tratado, num imbricado jogo de oposições, aponta uma púøıs harmônica, para a qual os opostos integram um todo, em complementação, e um vófos que fraciona, em opostos, o processo natural e valora suas partes, umas em relação às outras, e, como conclusão desse intrigante discurso, o tratadista propõe o último par antitético, formado, precisamente, por vó

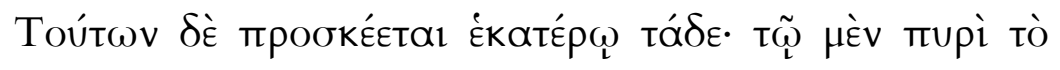

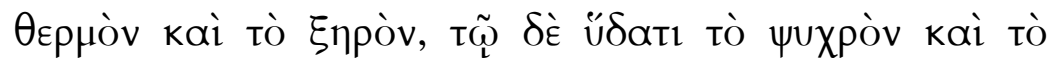

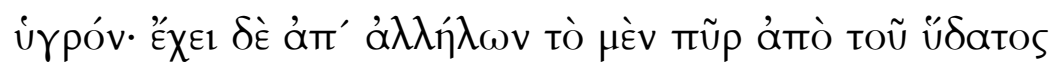

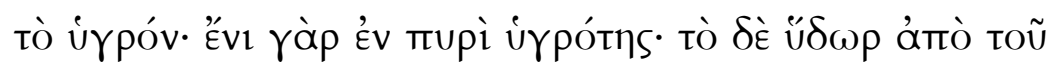

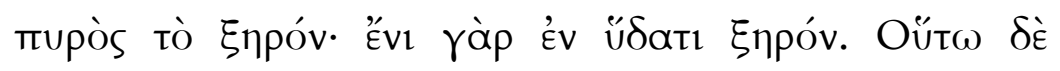

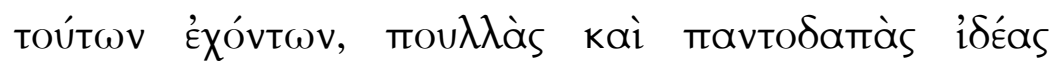

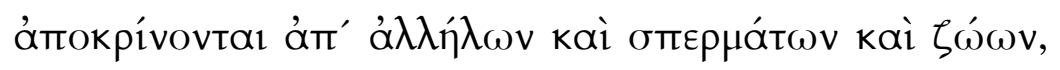

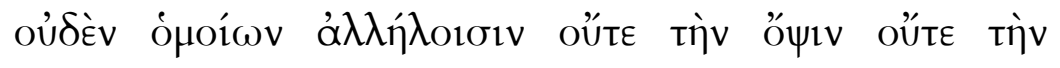

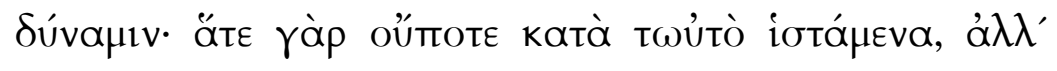

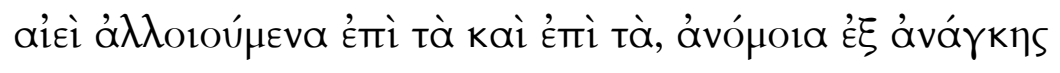

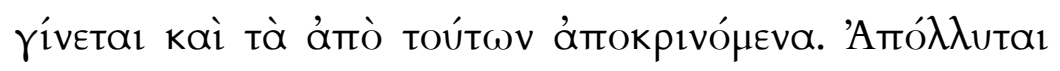

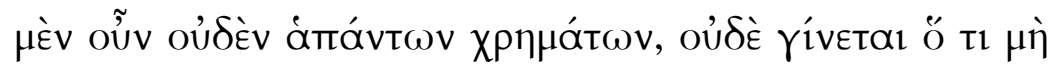

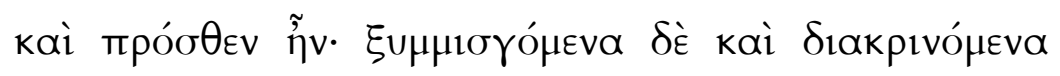




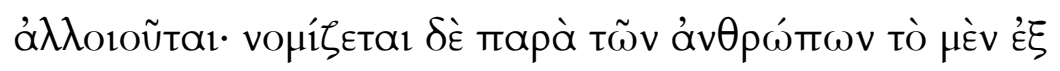

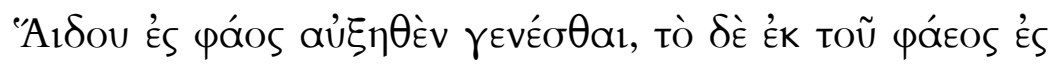

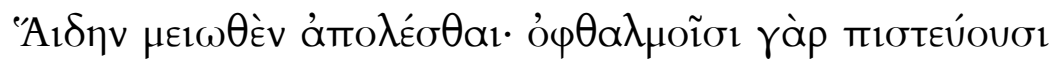

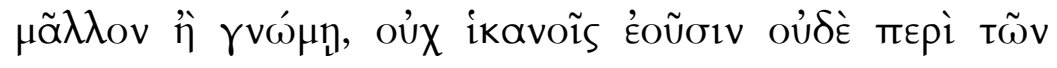

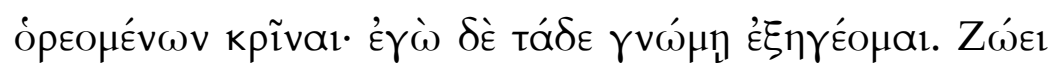

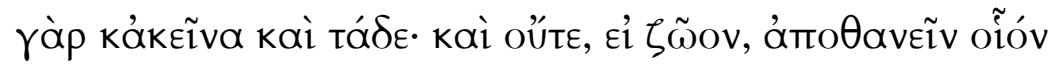

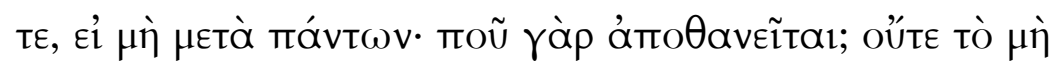

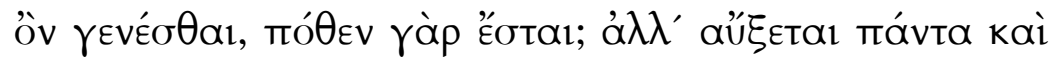

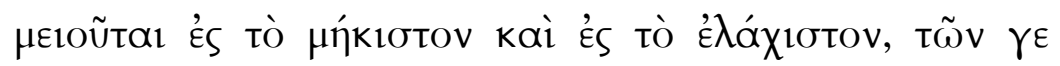

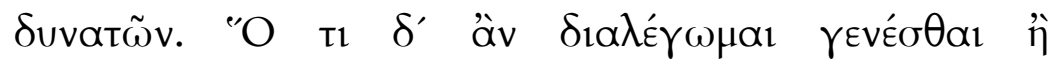

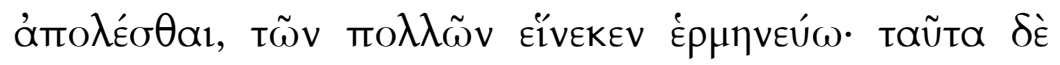

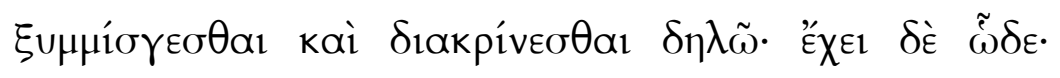

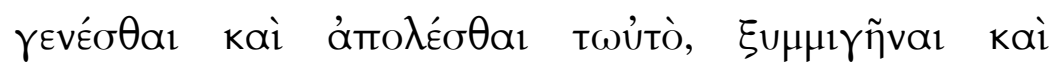

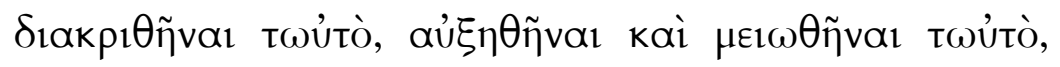

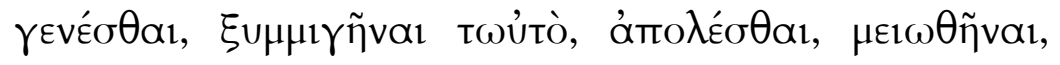

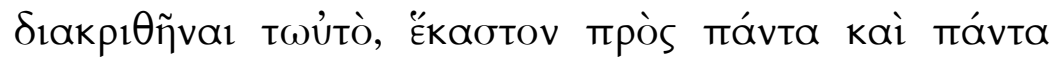

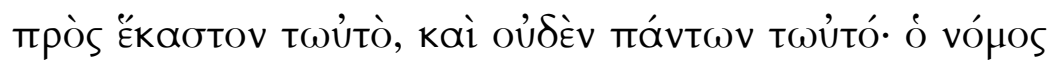

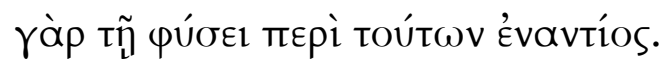

A cada um deles se designa o seguinte: ao fogo, o seco e o quente; à água, o úmido e o frio. E cada um tem do outro: o fogo tem da água o úmido, pois há no fogo umidade; e a água tem do fogo o seco, pois há na água secura. Sendo assim, em muitas e em variadas formas, secretam-se uns dos outros, as sementes e os animais, e nada têm entre si de semelhante, nem em aspecto nem em propriedade. Uma vez que eles nunca ficam em si, mas estão sempre mudando para um ou para outro, por necessidade, torna-se também 
dissemelhante ${ }^{20}$ o que é secretado deles. Portanto, de todas as coisas, nada perece nem nasce nada que não havia antes: o que se mistura e o que se separa muda. No entanto, entre os homens ${ }^{21}$ há a crença de que o que nasce cresce do Hades para a luz, e de o que perece míngua da luz para o Hades. Acreditam, pois, mais nos seus olhos do que no juízo, os quais não são capazes de julgar sequer o que veem. Mas eu explico essas coisas por meio do juízo ${ }^{22}$ : pois são animais tanto aqueles quanto estes: se é vivo, não pode haver morte, a não ser com o conjunto de todas as coisas, pois como morreria? Nem o que não existe nasceria, pois, de onde viria? Mas tudo cresce e tudo míngua para o máximo e para o mínimo das possibilidades. O que eu chamo de nascer ou perecer, por causa da plebe, assim interpreto, mas explicito [agora] que essas coisas são misturar-se e separar-se. Pois é assim: nascer e perecer é a mesma coisa; misturar-se e separar-se é a mesma coisa; aumentar e diminuir é a mesma coisa; nascer e misturar-se é a mesma coisa; morrer e separar-se é a mesma coisa, cada

${ }^{20}$ A conclusão desse raciocínio faz crer que o adjetivo óvónoı já faz ressoar a ideia de óvopía. A dissemelhança, de fato, é algo da ordem algo ligado à categoria nômica.

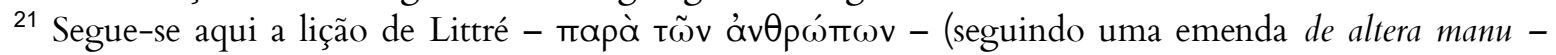

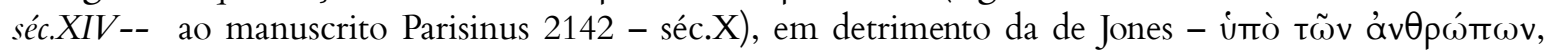
fundamentada no Parisinu2155.

22 Essa passagem parece inverter o binômio já clássico à época deste autor. Aqui vale referir o episódio narrado por Heródoto no livro I, o de Giges ante o pedido do soberano Candaules de ver a rainha da Lídia, sua mulher, nua, para que acreditasse que era ela a mulher mais bela de todas. A propósito desse

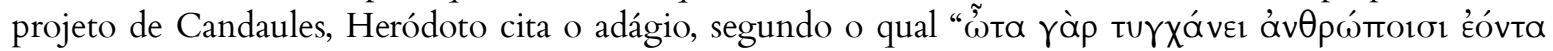

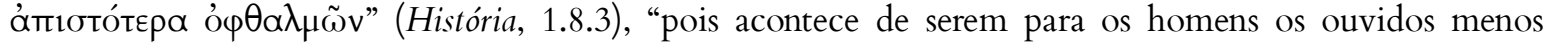
confiáveis do que os olhos”. Heráclito (fr.101a), citado por Políbio (Polib. XII 27), corrobora esse dito:

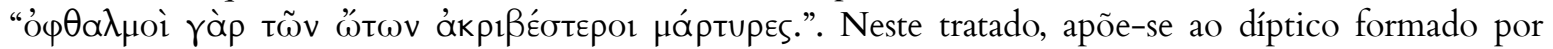
olhos e ouvidos a $\gamma v \omega ́ \mu \eta$, termo relacionado, a um só tempo, com a atividade intelectiva e a de inserção numa tradição. Seguindo esses passos, o pensamento relacionado à tradição impõe-se como o terceiro e mais importante elemento na constituição do conhecimento que se sabe devedor da ríotıs. 
um em relação a todos e todos em relação a cada um, e

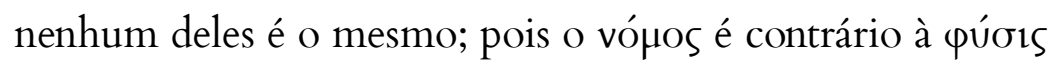
no que concerne a essas coisas. ${ }^{23}$

A distinção proposta pelo tratado entre os pares antitéticos, a partir da própria oposição entre púoıs e vó

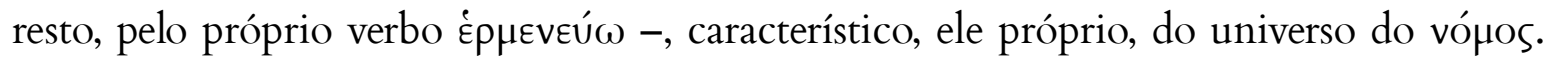
Por esse viés, a separação é uma hermenêutica do todo, e, talvez seja útil dizer, assim se entendia o método hipocrático; ao menos, desde a conhecida definição platônica de

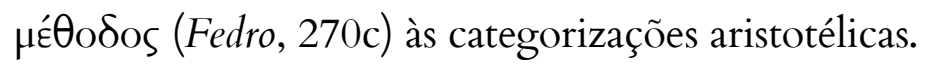

A catalogação, uma forma de categorização que se nota - ao menos - desde Homero, dá forma e conteúdo à descrição dos alimentos no tratado Da dieta. O critério

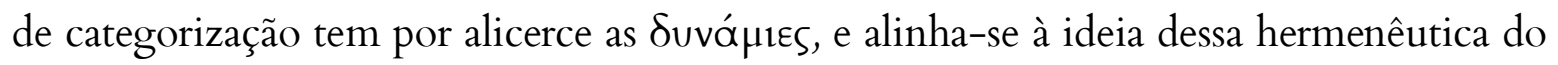

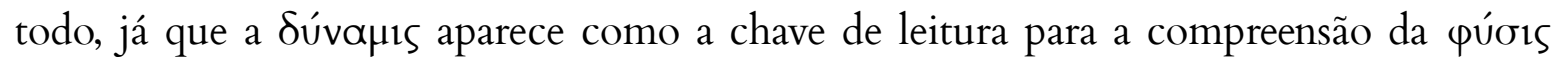
como um todo.

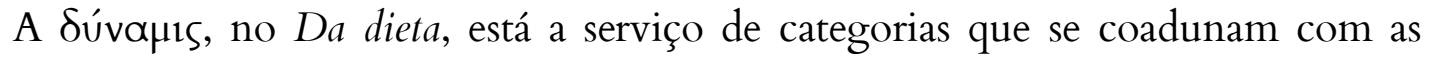
qualidades naturais, ou seja, as qualidades inerentes à púors, a saber, o 'seco', o 'úmido', o 'quente', o 'frio' e outras mais específicas, como 'picante', 'adstringente' etc., todas

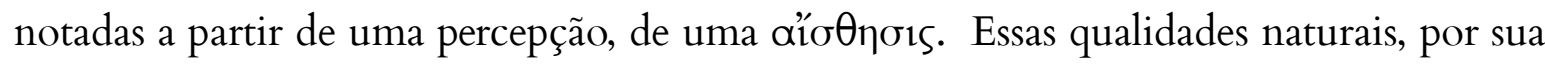
vez, são evocadas pelo discurso que acondiciona a púors ao binômio formado por 'fogo' e 'água'. A observação, a descrição e a prescrição do processamento dos alimentos integram a ação - sempre de base empírica - do médico e geram uma ação quase antitética - ou mesmo antitética - na elaboração, organização e formulação de conceitos. O conhecimento alegado das causas e da organização do microcosmos em relação ao macrocosmos ( $D a$ dieta, 1,10 et sq.) e a aplicação dessa ordem física aos

${ }^{23}$ De dieta, 1,4 


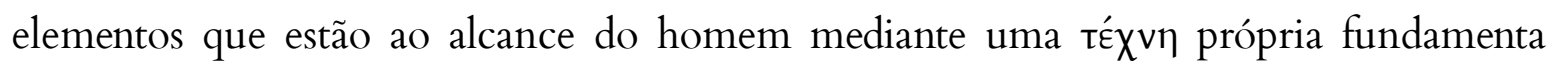
discursivamente a autoridade do médico e legitima o seu lugar de fala.

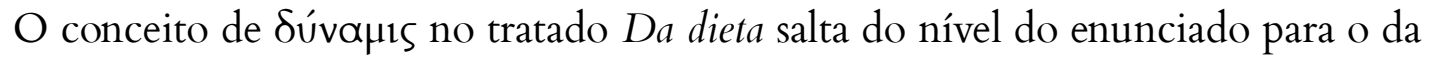
enunciação e suas formas. No livro I do Da dieta, o autor define a escrita como a

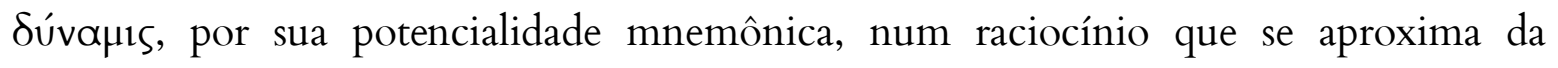
escrita-phármakon do Fedro platônico (274b-278b). Para além disso, refletir sobre a

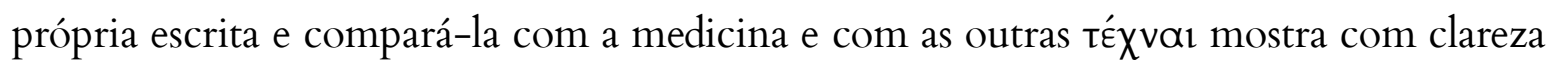

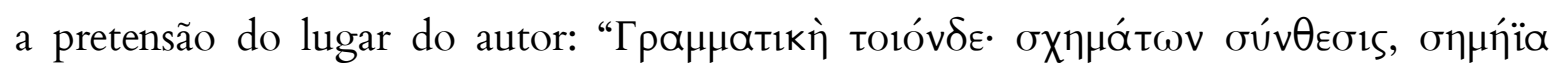

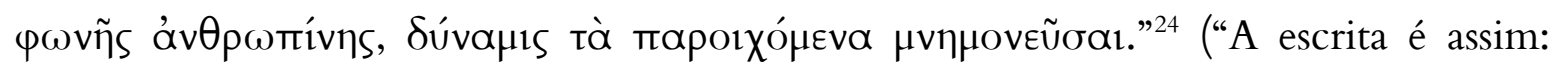
uma combinação de figuras, sinais da voz humana, a capacidade de relembrar os feitos

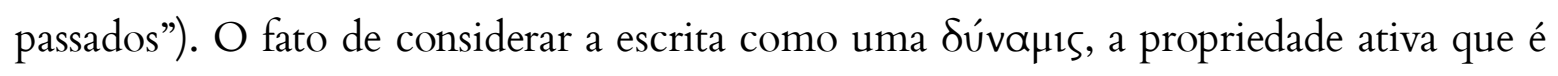
passível de observação e de manipulação - o que é, de certa forma, o objeto da sua obra -, denota sua atitude relativa ao seu projeto de composição do próprio tratado.

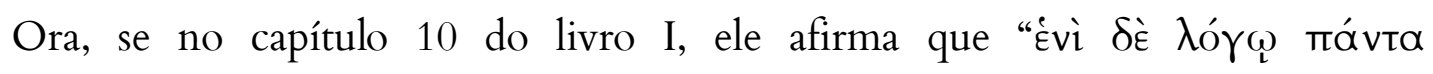

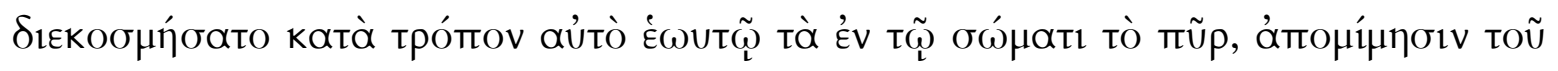

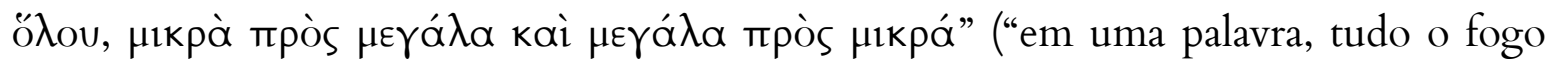
arrumou no próprio corpo por si mesmo, em imitação do todo, pequeno com grande e grande com pequeno"), e, logo depois, exemplifica a sua assertiva a partir do

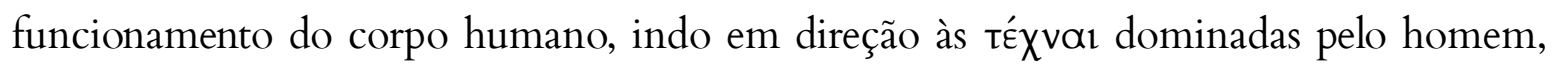
culminando na passagem acima citada, no capítulo 23 , acreditamos ser plausível a ideia de o nosso autor - enquanto um intpós que verte seu conhecimento na escrita - ter

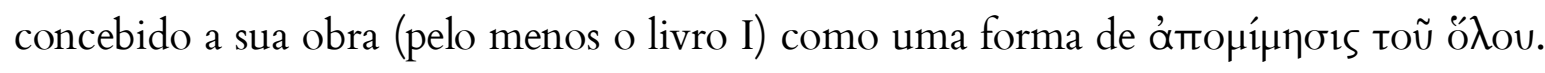
O capítulo 15, nesse sentido, ilustra bem essa ideia:

${ }^{24}$ Da dieta, I,23 


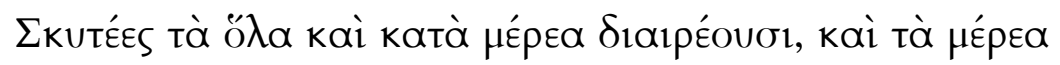

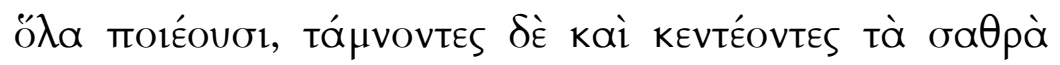

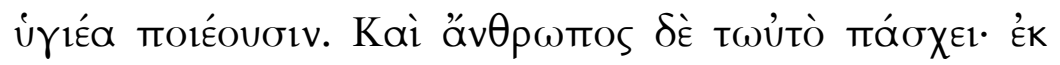

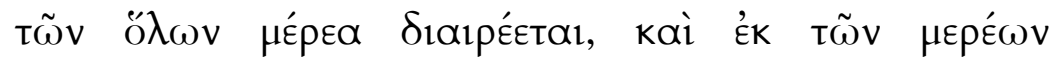

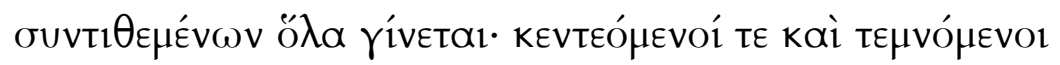

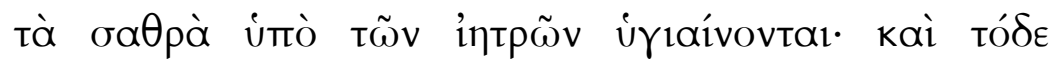

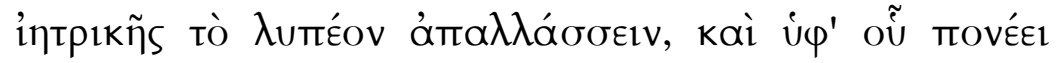

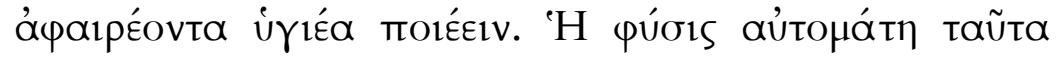

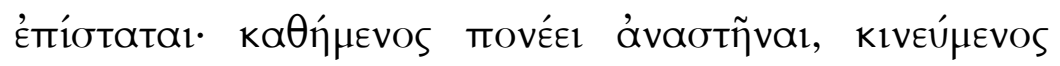

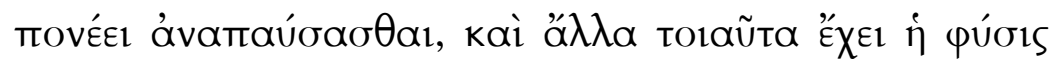
ītр1kñs.

Os curtidores dividem o inteiro em partes e tornam as partes coisas inteiras. Cortando e picando tornam são o que está putrefato. Com o homem se passa o mesmo: do inteiro divide-se em partes e, compondo-se das partes, se torna inteiro. Picados e cortados pelos médicos, tornam-se sãos. E isto é [próprio] da medicina, afastar o que provoca dor, e, ao fazer com que se afaste o sofrimento, tornar são. A púors por si mesma sabe isto: levantar o doente que está sentado e fazer repousar o doente que está em movimento, e outras coisas assim a púors tem da medicina.

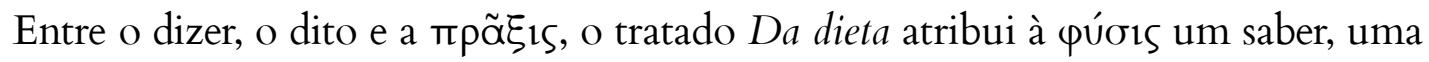

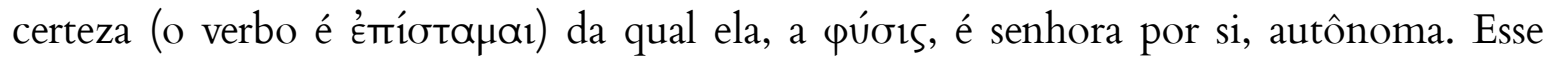
saber é o de indicar, sem equívoco, o que deve fazer o doente. Com isso, a púøıs partilha do domínio da medicina, por um certo saber relativo à ação. Essa é uma concepção de 


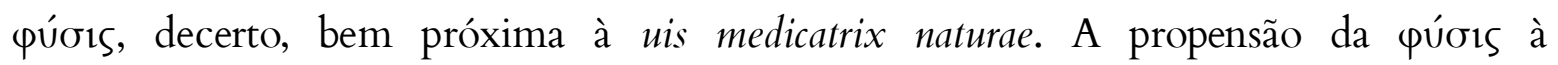
normalidade confere à própria normalidade um caráter natural; naturalizando, assim, por extensão, um $\tilde{\eta} \theta$ os ou mesmo um vó

A Síaıta, portanto, configura-se como um instrumento desse vó «os com o qual

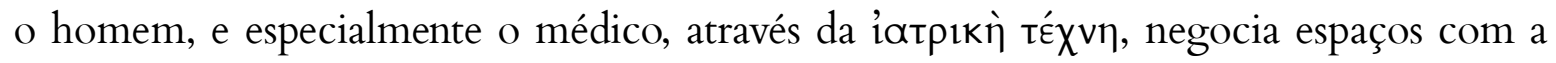
púors. Mais especificamente no tratado Da dieta, do ponto de vista da construção do conceito de saúde não como oposição à doença, ou como ausência dela, mas pretendendo-se um sistema perfeito que no caso específico deste tratado exclui a doença, colocando-a no lugar da anomia, de forma que o médico tratadista possa justificar

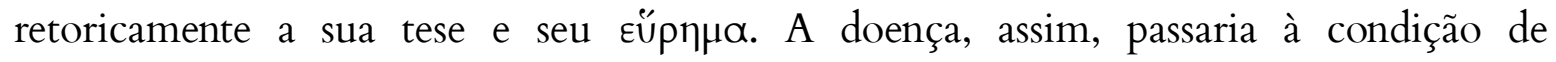
possibilidade no seu sistema de prodiagnose, situada no ponto extremo do esquema traçado pelo autor. Do ponto de vista da construção textual, tanto estruturalmente quanto na lógica interna do tratado, a partir da explicitação por parte do autor de uma consciência da sua própria escrita, é possível observar tais intentos discursivos. 


\section{O sono no Corpus hippocraticum}

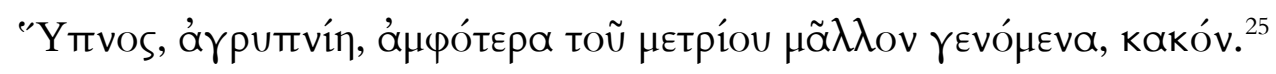
Sono, insônia, ambos sendo mais do que a medida, fazem mal.

$\mathrm{Na}$ passagem acima, que pertence ao livro II dos Aforismos, aponta-se que o excesso de sono ou a falta dele são prejudiciais. Em estrutura semelhante, no livro VII, o autor adverte que tais práticas provocam doença: "Y

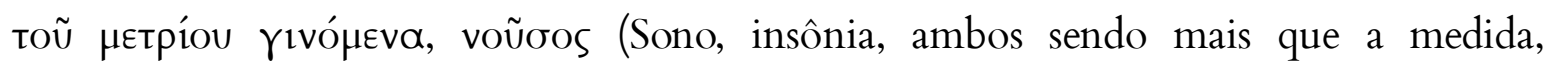
provocam doença). ${ }^{26}$

Não é surpreendente que os aforismos enfatizem a importância da moderação no sono ou na vigília, uma vez que essa medida natural para todas as coisas é uma das ideias

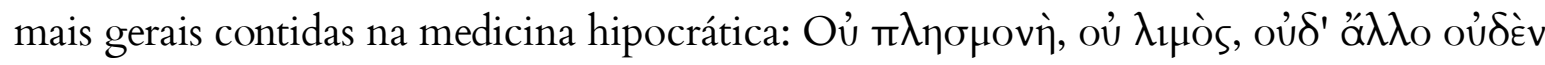

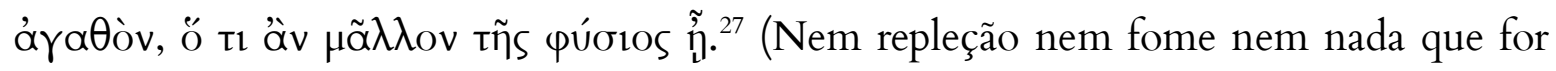
mais do que a púors é bom). Não é coicidência encontrar a palavra púors no lugar do

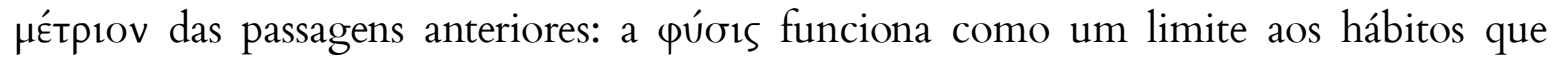
regulam o corpo e vice-versa.

Dados sobre a importância dessa moderação com vistas à saúde podem ser conferidos em grande parte do Corpus hippocraticum: para muitos, se não para quase todos os autores da Coleção, a saúde é vista a partir de um equilíbrio entre duas forças, e assim o excesso, bem como algum elemento externo que perturbe o equilíbrio interno, podem ser causa do adoecimento.

\footnotetext{
${ }^{25}$ Af. II, 3

${ }^{26}$ Af. VII, 72

${ }^{27}$ Af., II, 4
} 


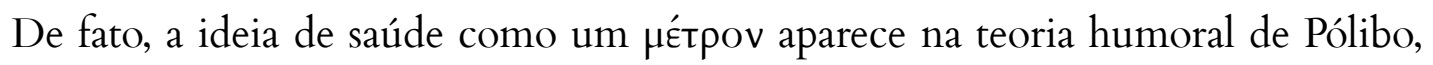
autor do tratado Da natureza do homem (4), em que tal conceito tem estreita relação com a proporção dos humores no corpo:

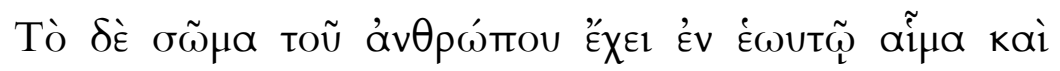

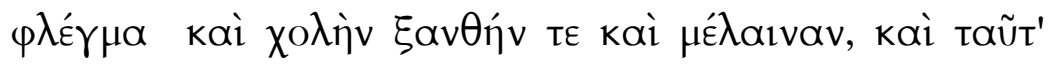

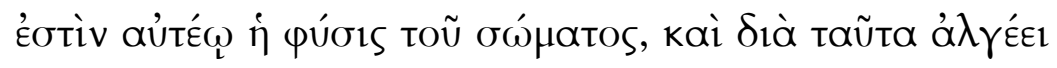

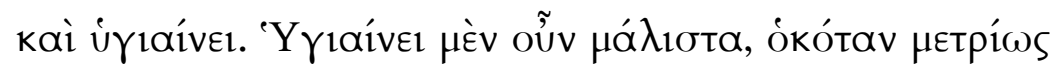

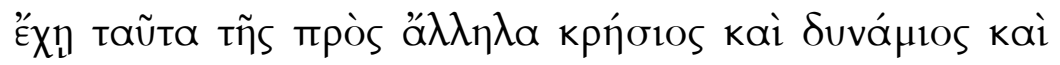

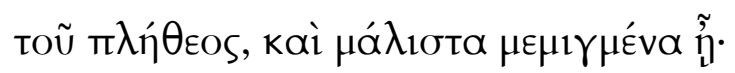

O corpo do homem contém sangue, fleuma, bile amarela e negra - esta é natureza do corpo, através da qual este adoece e tem saúde. Tem saúde precisamente quando esses humores são harmônicos em proporção, em propriedade em quantidade, e sobretudo quando são misturados. O homem adoece quando há falta ou excesso de um desses humores, ou quando ele se separa no corpo e não se une aos demais. $^{28}$

Diferente da de Pólibo, mas análoga à postura do tratadista do Da dieta, que será explorada mais à frente, a colocação do autor do Da medicina antiga com relação à saúde

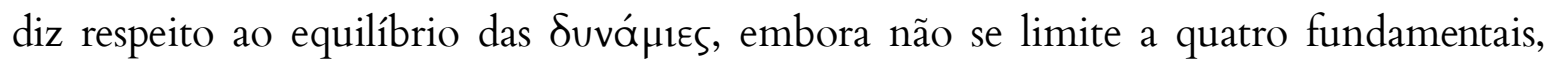

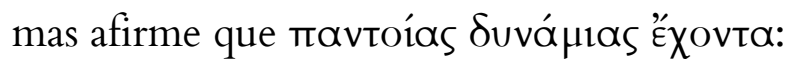

${ }^{28}$ Trad. Henrique F. Cairus, 2005, p. 43. 


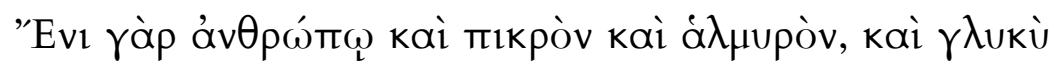

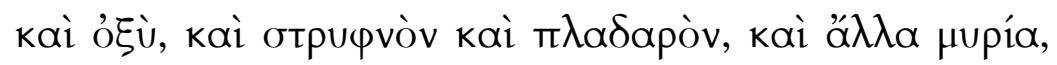

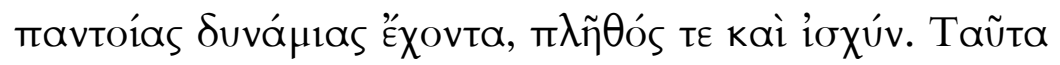

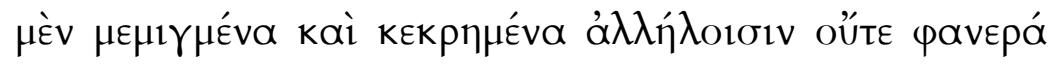

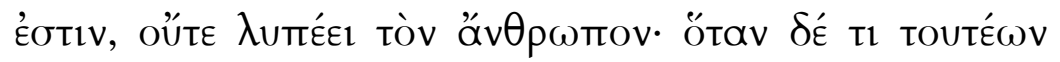

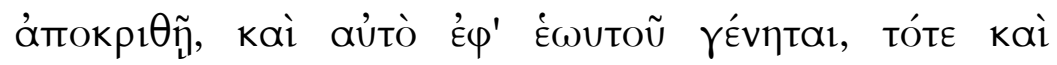

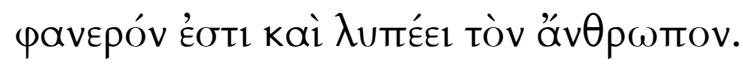

Há, de fato, o salgado, o amargo, o doce, o ácido, o azedo, o insípido e mil outras substâncias possuem propriedades diversas em relação à quantidade e à força. Essas coisas, misturadas e temperadas uma a uma, não estão manifestas e não fazem o homem padecer; mas, quando uma delas se separa e se isola, então ela se torna manifesta e faz o homem padecer. $^{29}$

A definição de saúde do tratadista do $D a$ dieta, talvez a definição mais significativa encontrada no Corpus hippocraticum, associa-se à proporção justa entre alimentos e exercícios, cada um representando um dos princípios fundamentais da homeostase, a saber, o esvaziamento e a repleção.

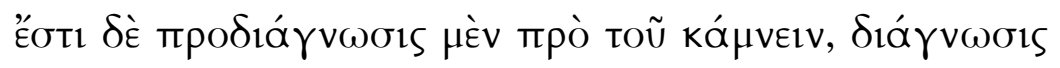

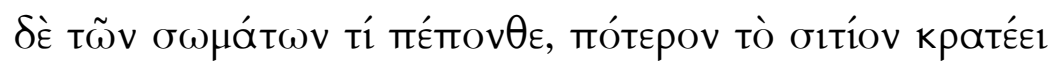

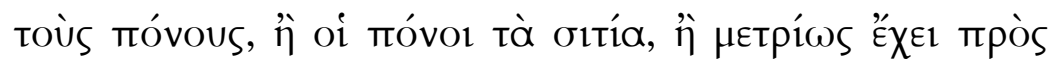

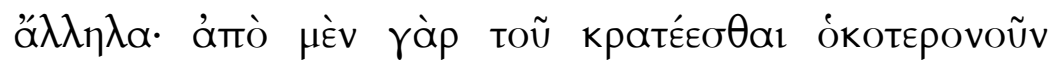

\footnotetext{
${ }^{29}$ Trad. Henrique Cairus
} 


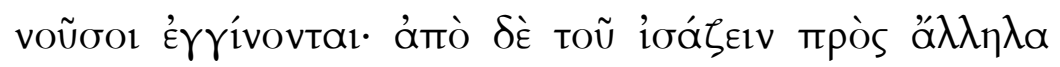

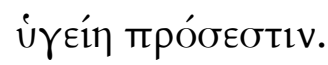

É uma prodiagnose antes do adoecimento, uma diagnose do que ocorreu aos corpos, seja se o alimento domina os esforços ou se os esforços [dominam] os alimentos, ou se há equilíbrio entre si. Pois as doenças ocorrem a partir do domínio de cada um, e a saúde provém da igualdade entre eles.

O autor do Prognóstico acredita que habitualmente o homem deve seguir um padrão de sono e dormir durante a noite e estar acordado durante o dia:

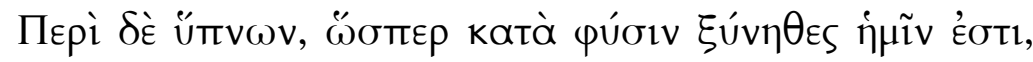

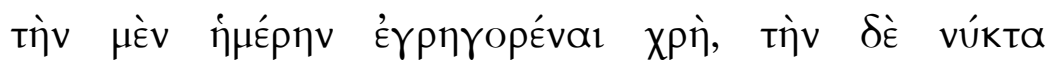

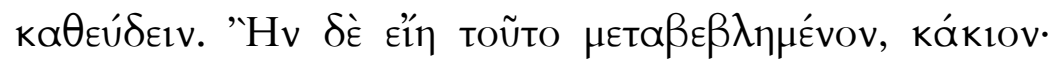

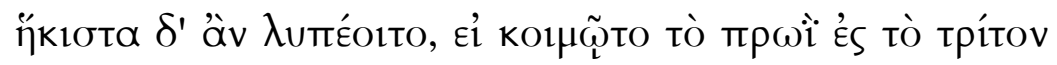

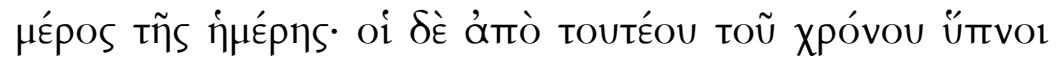

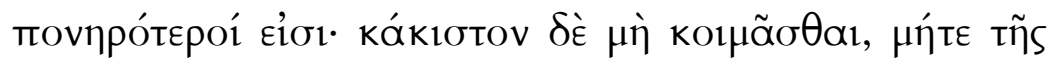

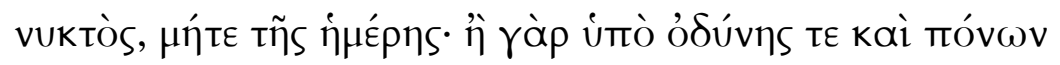

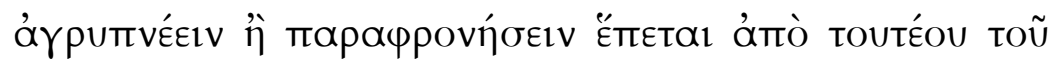

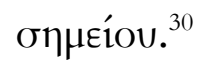

Sobre o sono, assim como é por natureza habitual para nós, é preciso que se esteja acordado durante o dia e dormir durante a noite. Se isso for mudado, faz mal. Menos mal

${ }^{30} \operatorname{Prog} 10$ 
faria se se dormisse cedo até a terceira parte do dia. O sono após esse período é daninho; pior é não dormir, nem de noite, nem de dia. Pois se houver vigília/insônia sob dor e mal estar, após esse sinal, segue-se o delírio.

Dormir à noite e ficar acordado durante o dia é exatamente como deve ser, porque é o caminho natural das coisas (katò púoıv). Se qualquer mudança ocorrer com esse padrão, não é um bom sinal, o autor prenuncia, e, logo depois, estabelece os vários graus de gravidade possíveis. É menos perigoso se alguém dorme o primeiro terço do dia; dormir depois disso não é bom, e é pior quando não se dorme. Uma completa falta de sono é vista como um sinal de problemas mais graves.

Para o autor do Da dieta, em algumas estações, esse padrão é insuficiente para manter a saúde e, por isso, deve-se tirar sonecas breves no verão, para evitar que o corpo

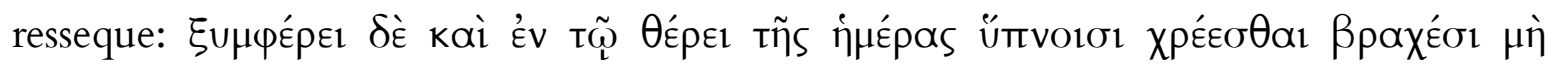

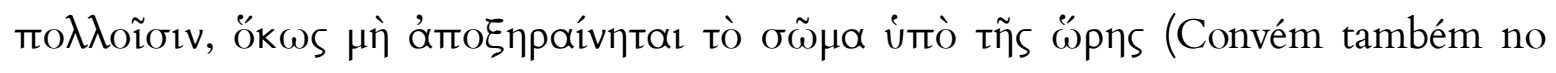
verão tirar não muitas sonecas breves durante o dia, de forma que o corpo não resseque por causa da estação). Nesse caso específico, o sono possui propriedade úmida no corpo, e, de resto, é utilizado nas prescrições de dietas úmidas ${ }^{31}$. Entretanto, segundo o autor do mesmo livro no capítulo 60, do livro II, o sono tem diferentes propriedades, dependendo da circunstância:

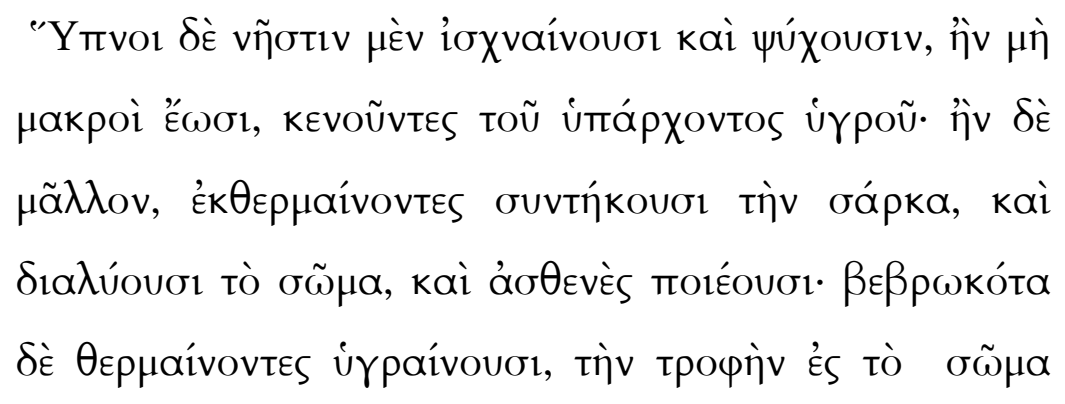

${ }^{31}$ Ver também Da dieta IV, 89 e III, 71. O autor aqui acredita que há sono em caso de haver excesso de

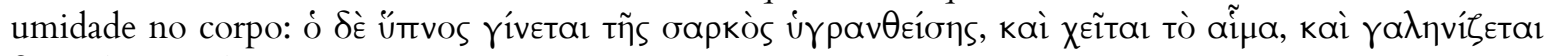
$\delta 1 \alpha \chi \in o ́ \mu \varepsilon v o v$ tò $\pi v \varepsilon \tilde{u} \mu \alpha$. 


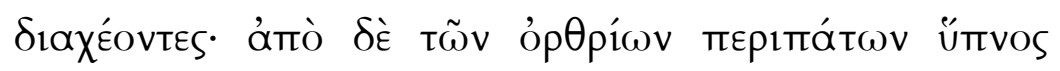

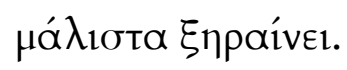

O sono em jejum emagrece e esfria, se não for muito longo, enchendo (o corpo) da umidade existente; se for muito, esquenta e liquefaz a carne, relaxa o corpo e provoca fraqueza. O sono após ter comido esquenta e umedece e espalha a nutrição no corpo. Após as caminhadas matutinas o sono seca muito mais.

A ideia que aqui subjaz é a de que o corpo deve-se adequar a condições externas, como o clima, de modo a não romper o equilíbrio interno do corpo, uma vez que fatores externos podem ser causa de adoecimento. Regular os hábitos de sono de acordo com esses fatores externos parece ser uma forma de alcançar essa adequação. $O$ compilador dos Aforismos assim diz, acerca do sono no inverno e na primavera:

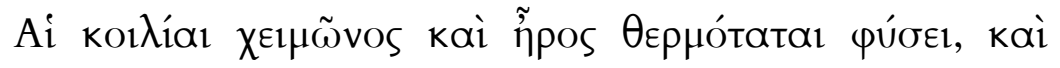

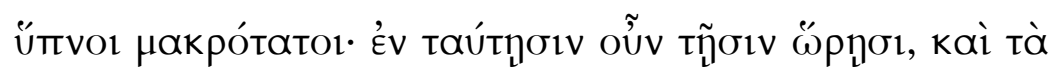

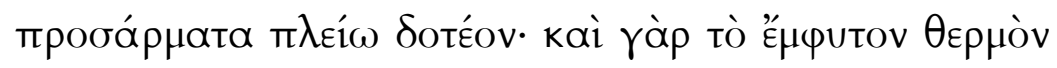

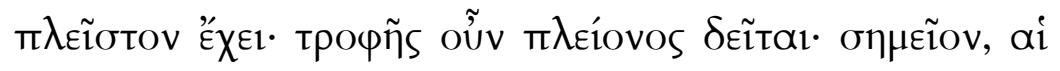

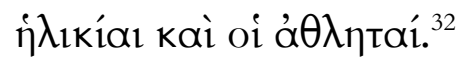

A barriga esquenta por natureza durante o inverno e primavera, e o sono é mais longo. Nessas estações é necessário dar mais comida, pois o calor natural interno é

\footnotetext{
${ }^{32}$ Af. I, 15
} 
maior, então precisa mais nutrição. Sinal disso são os jovens e os atletas.

O que essa passagem parece sugerir é um paralelo entre a constituição dos jovens e dos atletas e o dos corpos nas estações do inverno e da primavera, uma vez que, por natureza, ambos são quentes. Traça-se aqui uma estreita relação entre o sono, o calor e a

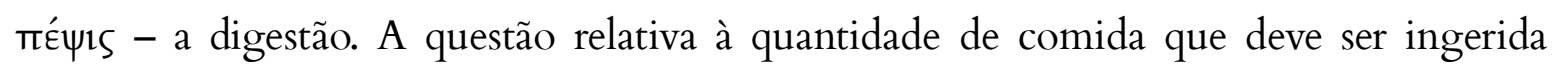
nessas estações pode ser explicada pelo aforismo anterior a esse, em que se afirma que,

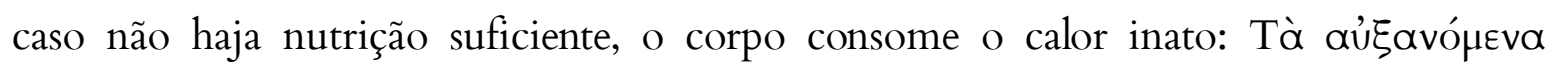

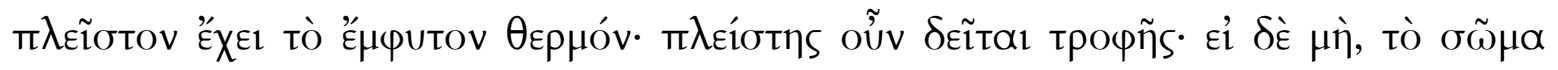

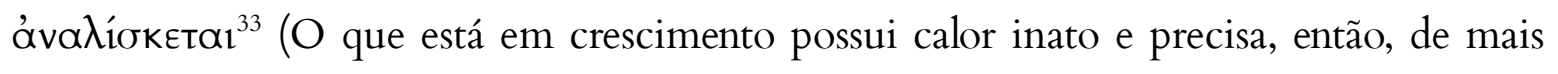
nutrição. Caso contrário, o corpo o consome).

Apesar de não haver no Corpus hippocraticum uma explicação clara sobre a causa do sono, temos alguns indícios em algumas passagens que dão conta do funcionamento desse processo. Parece razoável pensar que as propriedades fundamentais que aparecem em muitos dos textos do $\mathrm{CH}$, o quente, o frio, o seco e o úmido, tenham influência sobre ele.

\footnotetext{
${ }^{33}$ Af. I, 14
} 


\subsection{O sono e as $\delta u v a ́ \mu 1 \varepsilon \varsigma$}

Em vários tratados, o fogo aparece como o elemento-chave para o princípio da vida, por ter a propriedade de atrair $\pi v \varepsilon \tilde{u} \mu \alpha^{34}$ para si. Assim, funciona como o elemento motor dos processos do corpo. Geralmente nas passagens que o mencionam, o sono vem associado ao calor (ou falta dele).

O autor do tratado Da dieta acredita ser o fogo e a água os elementos primordiais

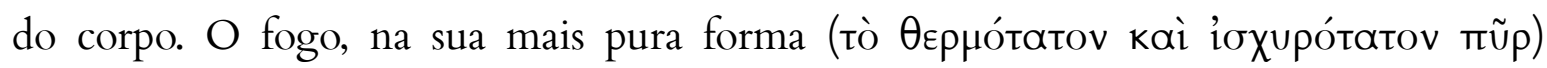
funciona como o motor que dá movimento e que gera vida em todas as suas formas e é responsável por todas as funções do corpo, inclusive o sono e a vigília.

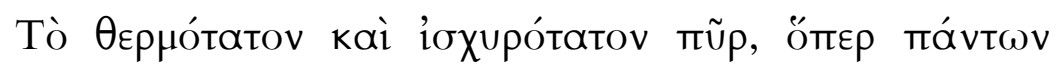

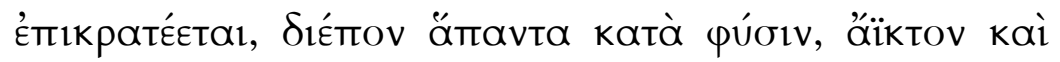

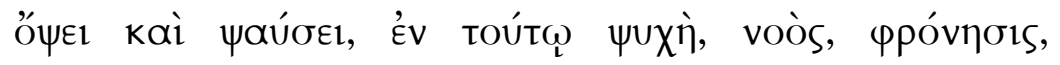

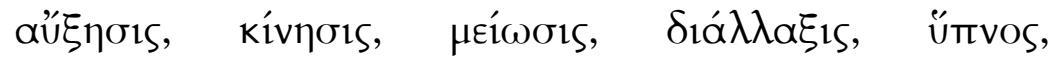

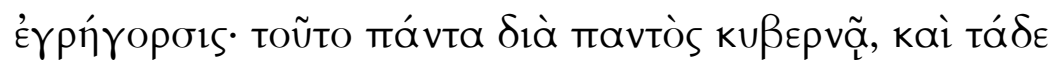

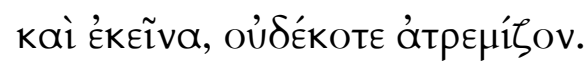

O mais quente e forte fogo, que tudo domina, organiza tudo de acordo com a púoıs, inalcançável tanto à vista quanto ao tato, e nele está a alma, a mente, o pensamento, o crescimento, o movimento, a diminuição, a separação, o sono e a vigília. Ele conduz tudo a partir de tudo, tanto isso quanto aquilo, nunca permanecendo parado.

\footnotetext{
${ }^{34}$ Cf. Das carnes 6; Da natureza da criança, 12; Da dieta I. 9; 27. Cf. Joly, R.; Byl, S. (1966), p.41sq
} 
O autor do tratado Epidemias VI oferece uma explicação sobre o que acontece no corpo durante o sono. Segundo ele, no sono, o sangue foge para o mais interior do

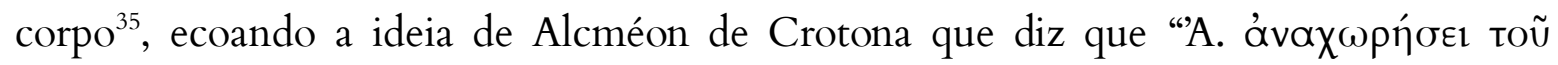

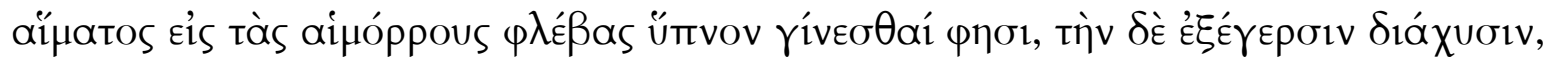

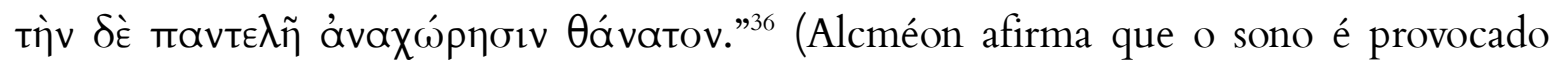
pela retração do sangue nas veias sanguíneas e a vigília, a difusão e a morte, a retração total).

A isso pode-se somar a asserção do próprio autor de que uma pessoa é quente no exterior e fria no interior quando está acordada, e quente no interior e fria no exterior quando dormindo, levando em consideração a associação corrente do sangue com o

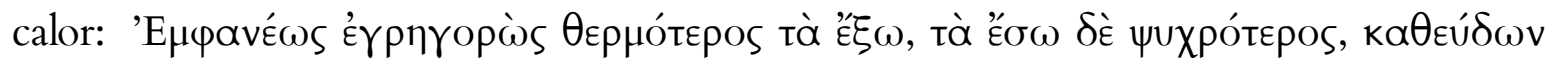
tớvavtía. (Quando evidentemente acordado, é mais quente na parte de fora, e mais frio na parte de dentro, dormindo é o contrário) ${ }^{37}$.

A relação do calor com o sangue e o processo digestivo parece ter sido amplamente discutida pelos physiológoi e parece ter sido absorvida e sem refutação pelo pensamento hipocrático. A respeito disso, Vivian Nutton explica:

Digestion was, in part, a mechanical process: food was cut and ground by the teeth before passing to the stomach, where it then underwent a process of putrefaction, probably under the influence of the body's natural heat, before being sent to the liver, where it was turned into blood. Heat,

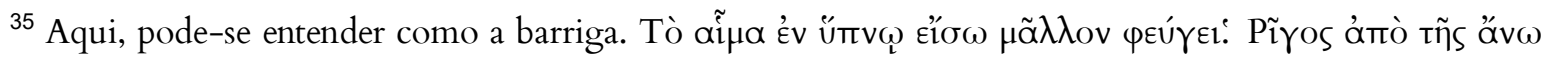

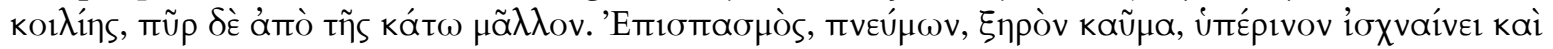

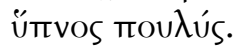
${ }^{36} 24 \mathrm{~A} 18 \mathrm{DK}$

37 Epid. VI, 4, 12. Simon Byl, em seu artigo "Sommeil et insomnie dans le Corpus Hippocraticum" (1998:36) assinala que essa ideia está presente nos escritos de vários outros pré-socráticos, como Empédocles, Anaxágoras e Leucipo. Para outro artigo a respeito das teorias do sono nos pré-socráticos, ver C. Marelli, "Place de la Collection hippocratique dans les théories biologiques sur le sommeil", in F. Lasserre et Ph. Mudry, Formes de pensée dans la Collection hippocratique (Actes du IVe Colloque international hippocratique), Genève, 1983, pp. 331-333.
} 
which Parmenides had equated with life, played a major role in Empedocles' view of the human body, being used to account for the differences between the sexes (males are hotter and better cooked than females) and to explain sleep (as a cooling process). Blood was the agent of nutrition, and maternal milk was the result of the decomposition of superfluous blood. ${ }^{38}$

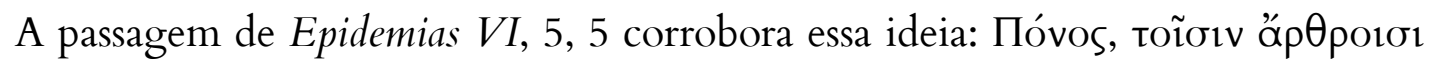

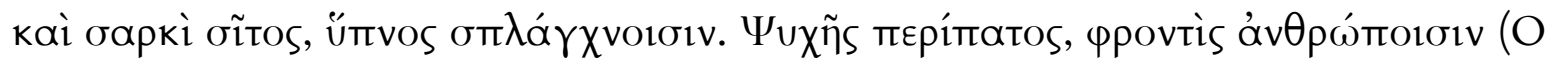
exercício físico é alimento para as articulações e carnes; o sono, para as vísceras. Exercício da alma é o pensamento para os homens).

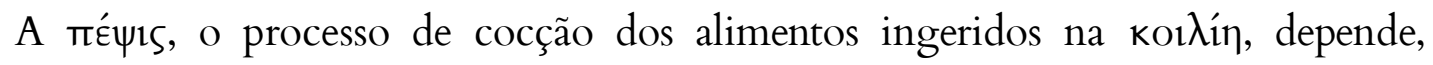
assim, desse calor inato que nessa cavidade se concentra, portanto, quanto mais calor, melhor será a digestão. Dessa forma, durante o sono, que é o momento no qual há uma concentração maior de calor na cavidade central, vem a ser quando a digestão é mais eficaz. Por isso, para a maioria das prescrições dietéticas, o sono costuma servir como eixo organizador entre refeições e exercícios.

Nesse sentido, o já citado capítulo 60 do livro II do Da dieta apresenta as diferentes propriedades que o sono pode ter, dependendo da atividade com a qual se associa. Tais propriedades poderiam assim ser esquematizadas:

- O sono após a refeição umedece e esquenta;

- O sono em jejum resseca;

- O sono excessivo em jejum esquenta;

- O sono após as caminhadas matutinas resseca;

${ }^{38}$ in Ancient Medicine, 2004, p.47 
- A falta de atividade umedece;

- Atividades como o trabalho resseca;

No capítulo 80 do mesmo tratado, quando se aborda o desequilíbrio no ventre provocado pelo excesso de exercícios, recomenda-se, entre outras medidas, dormir

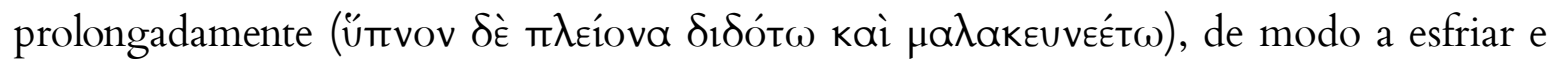
ressecar o que está excessivamente quente e úmido como consequência da perturbação. Semelhantemente, uma passagem do tratado Da dieta salutar ${ }^{39}$ propõe como tratamento para a indigestão causada pelos alimentos que são ingeridos um sono prolongado: Kaì

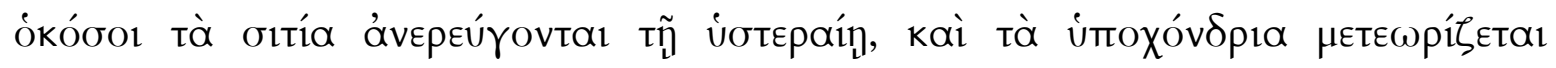

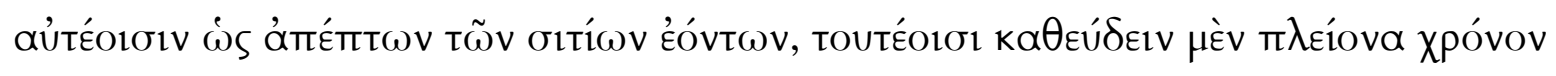

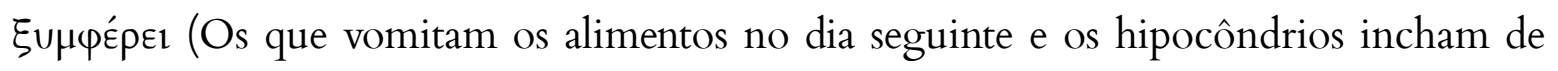
modo que os alimentos consumidos não são digeridos, a eles convém dormir durante muito tempo).

Além das propriedades quente e úmido, as outras duas propriedades principais, seco e frio parecem ter parte na causa do sono. No capítulo 71 do Da dieta, pode-se observar a influência delas no processo:

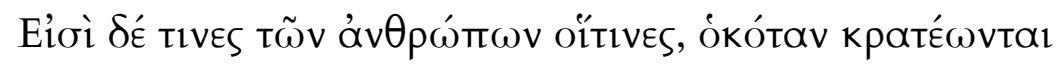

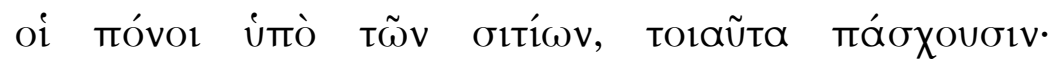

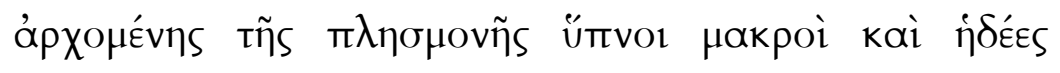

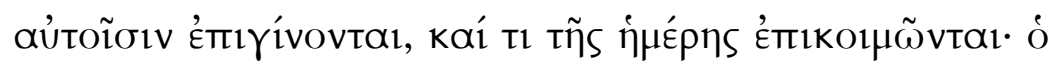

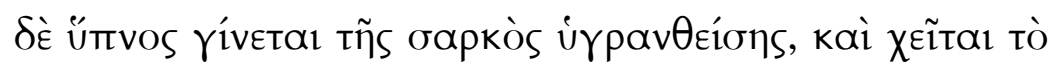

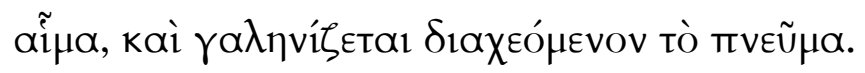

Há alguns dentre os homens que, quando os exercícios são dominados pelos alimentos, sofrem isto: durante o início da

${ }^{39}$ Da dieta salutar, 7 
saciedade, têm sonos longos e agradáveis para eles e dormem parte do dia. Pois o sono vem da carne umedecida, o sangue se difunde e o ar liquefeito se acalma.

Em Epidemias VI, é possível perceber uma concepção um tanto diferente, pois aqui, a propriedade da água, o úmido, é a responsável não pelo sono, mas pela insônia:

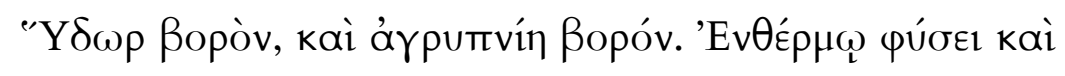

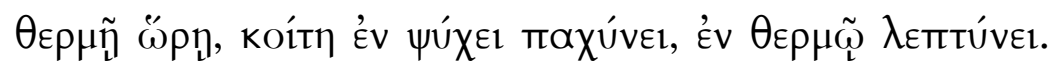

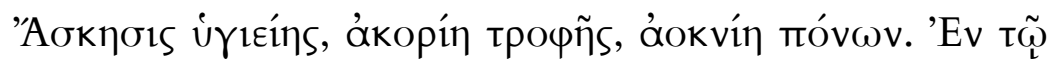

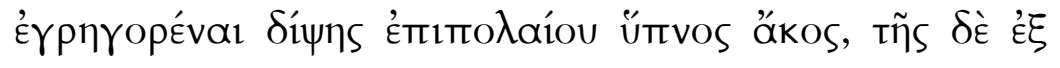

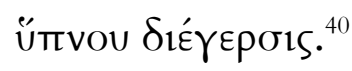

A água produz o glutão, assim como o produz a insônia. Para uma natureza quente e para uma estação quente, deitar-se no frio engorda, no calor, emagrece. Exercício de saúde, moderação ${ }^{41}$ de alimento, perseverança de exercícios. $\mathrm{Na}$ vigília, o sono é remédio para a sede leve, e o despertar [é remédio para a sede leve] que vem do sono.

$\mathrm{Na}$ passagem acima, o autor de Epidemias VI faz clara a relação que a água tem com a insônia. "Ingerir água produz o glutão, assim como o faz a insônia", ele afirma. Não só o faz, como também introduz o dado do excesso, através do uso do termo

\footnotetext{
${ }^{40}$ Epid VI, 4,18.

${ }^{41}$ Apesar de já ter utilizado o termo "moderação" como tradução para "mésos”, aqui pareceu adequado utilizá-lo, uma vez que aponta para o mesmo sentido.
} 
ßopóv, que significa glutão, mas também - e principalmente - pelo uso do termo ákopín, como uma negação do kópos, frequentemente associado a uma úßpıs. ${ }^{42}$

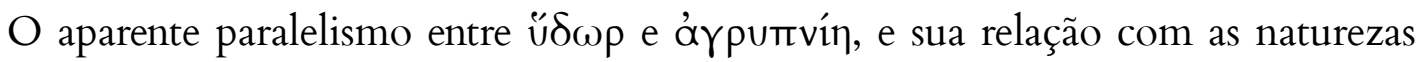
quentes - tanto no aspecto micro quanto no macrocósmico -, não é exclusividade desse texto, mas aparece em quase todos os tratados de Epidemias (livros I, III, V, VI e VII), bem como no Prorrético, Doenças das mulheres, Prenoções coicas, entre outros.

Da mesma forma, a sede, entendida como um efeito provocado pela consumição da água pelo calor inato do corpo durante o sono, aparece não só nesse livro, mas também em todos os outros do mesmo tratado (ainda que tenham autorias diversas, o que leva a crer em um consenso a respeito do assunto), associada à insônia. Porém, o autor de Epidemias VI parece distingui-la da sede provocada durante o estado de vigília. Diferente da vigília, que, em outros tratados, relaciona-se ao frio (ausência do calor), a insônia parece pertencer ao eixo das $\delta$ uvá $\mu 1 є \varsigma$ seco-úmido.

No tratado Ares, águas e lugares, é possível ver como a sonolência é associada às pessoas com compleição úmida, que habitam regiões também úmidas:

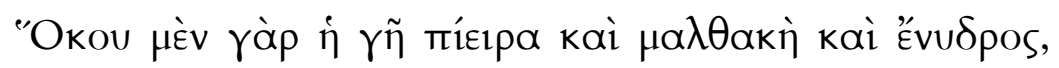

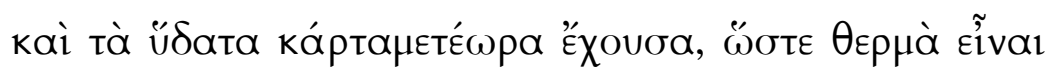

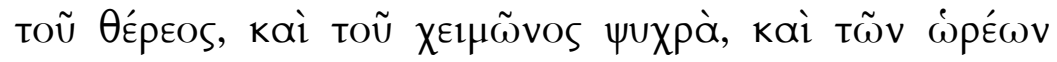

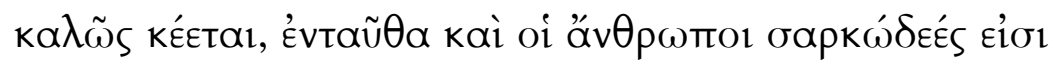

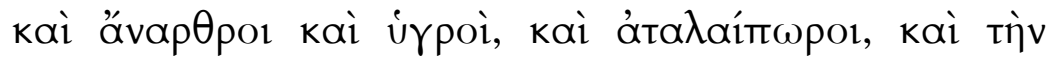

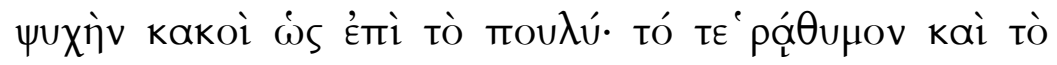

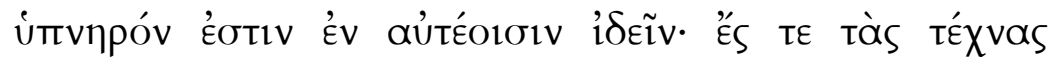

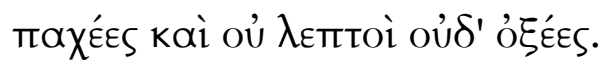

\footnotetext{
$42 \mathrm{O}$ termo kóros significa "saciedade" e se encontra no mesmo campo semântico do excesso que altera o equilíbrio corporal, estreitamente ligado à saúde. O termo kóros é frequentemente tido como o resultado

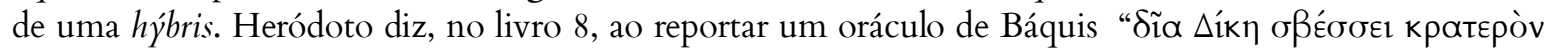
kópov, üßpros vióv (Hdt.8.77).
} 
Onde a terra é fecunda, macia e abundante em água, e as águas são fortemente elevadas, de sorte a serem quentes no verão e frias no inverno, e, durante as estações tudo ocorre bem, nesse lugar, também os homens são carnudos e sem articulações visíveis, são úmidos, sem vigor e geralmente têm a alma de má qualidade; a indolência e a sonolência estão dentro deles, e mesmo para o ofício eles são gordos, e não lépidos e precisos. ${ }^{43}$

No seguinte parágrafo, o tratadista propõe o contrário: às pessoas que habitam regiões secas e áridas, com características corporais semelhantes, associa-se a falta de sono ou insônia:

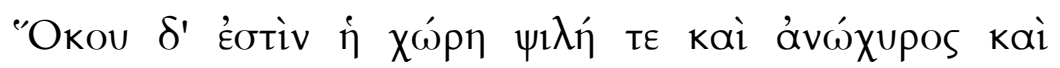

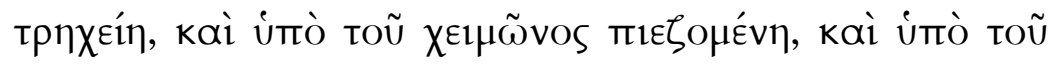

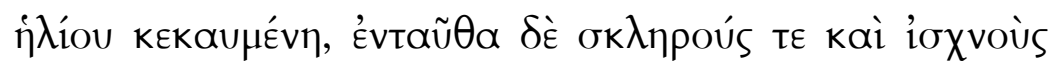

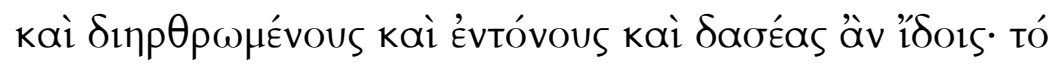

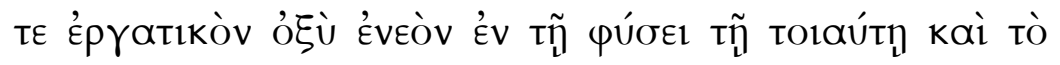
árputrvov, tá te

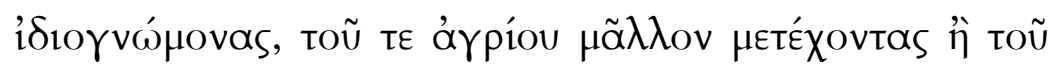

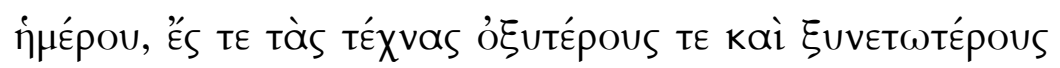

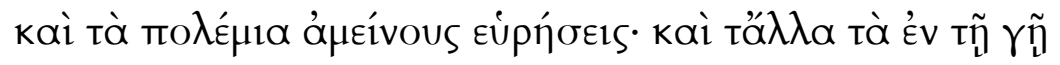

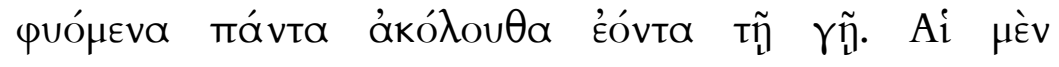

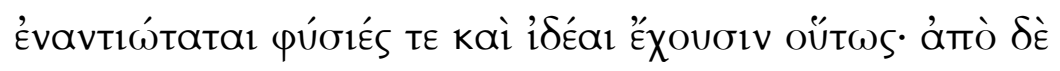

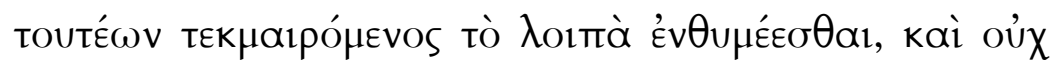

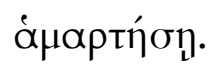

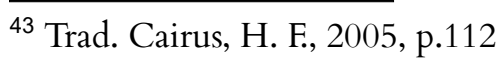


Onde a região é sem vegetação, sem água, acidentada e oprimida pelo inverno e queimada pelo sol, nesse lugar, encontrarás homens rijos, magros, com articulações visíveis, tonificados e cabeludos, e, presentes em tal natureza, encontrarás um profundo espírito de trabalho, um sono difícil; os caracteres e sentimentos, encontrá-los-ás arrogantes e independentes, participando mais da selvageria do que da docilidade, mais precisos nos ofícios e mais argutos, e, nas atividades belicosas, mais bravos; encontrarás, ainda, todas as outras coisas que nascem na terra acompanhando sempre a própria terra. As naturezas e as conformações mais contrárias são assim. Considerando o restante a partir dessas coisas, não errarás. ${ }^{44}$

A umidade, aqui, aparece diretamente associada ao sono, seja na presença ou na falta dela. A ausência d'água num espectro maior da púoıs tem efeito semelhante na composição do corpo dos nativos dessas regiões e é refletida nos seus hábitos de sono.

O sono é, assim, influenciado por quatro fatores, em dois eixos: enquanto a umidade e a sequidão favorecem a formação das naturezas externas e internas que ditam um certo estado de normalidade e também funcionam como fatores de indução ao sono, o eixo calor-frio parece ser o responsável pelos mecanismos corporais internos que funcionam durante o sono.

No Corpus hippocraticum, o sono aparece como um elemento do prognóstico, e é abordado a partir da sua presença ou ausência, em estados do normal ou patológico. É

${ }^{44}$ idem, ibidem. tò ớrpurnvov aqui é traduzido mais amplamente como "falta de sono". A associação da agrypnía, a insônia, com uma natureza selvagem faz jus à palavra, que, etimologicamente, significa "sono selvagem". 
tomado como um dos elementos para a manutenção da saúde. Por outro lado, a insônia, vista como a ausência de sono, e, portanto, entendida como algo que foge do princípio da justa medida, nunca é vista como algo bom. Em certas passagens do Prorrético e das Prenoções coicas, por exemplo, há a clara indicação da insônia, entre outros sintomas, como algo Kakó $v^{45}$.

A insônia, assim, aparece no texto geralmente como sintoma de doença ou de alguma perturbação no corpo. No já citado capítulo 10 do Prognóstico, a mera dor

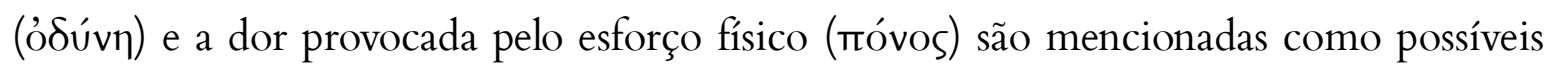

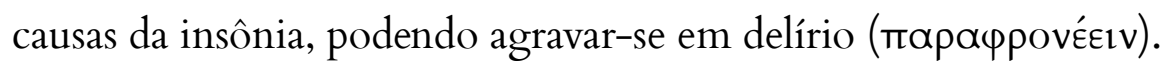

Os estudos de caso de Epidemias III, curiosamente, colocam a insônia junto a outros sintomas graves de doenças. É o que se pode notar no trecho abaixo:

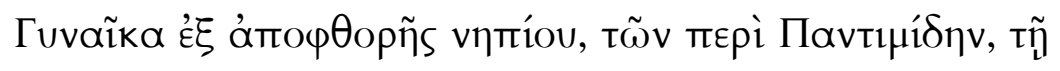

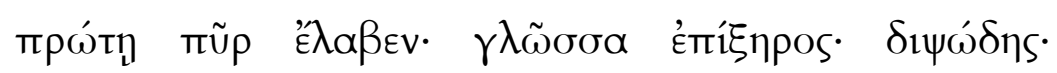

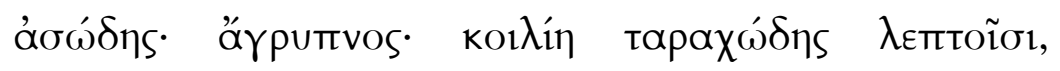

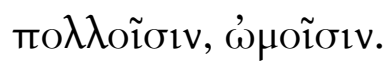

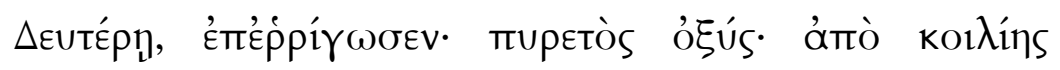

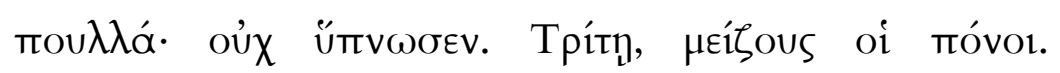

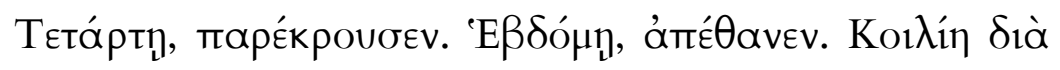

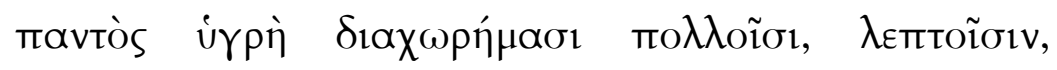

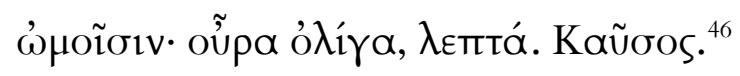

Uma mulher dos de Pantimides, após ter abortado, no primeiro dia, pegou uma febre; língua seca; sedenta;

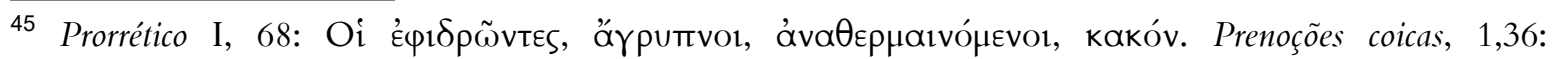

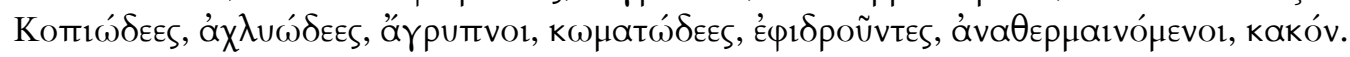

${ }^{46}$ Epid. 3.2.10 
nauseada; insone. $\mathrm{O}$ ventre perturbado com excrementos leves, em grande quantidade, crus. No segundo dia, teve calafrios; febre aguda, muitos excrementos no ventre; não dormiu. No terceiro dia, dores maiores. No quarto dia, perdeu o juízo. No sétimo dia, morreu. O ventre por toda parte úmido, com muitos excrementos, finos, crus; pouca urina e leve. Febre cáustica.

No livro II dos Aforismos o autor começa explicando que, se o sono causar dor física durante uma doença, isso sinaliza a morte. Por outro lado, se o sono for benéfico,

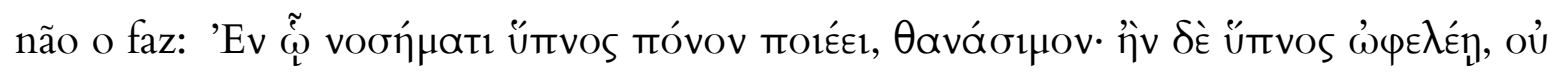
Aavóouıov. (Se durante uma doença o sono provocar dor física, é funesta, se o sono for benéfico, não é funesta). Em outras palavras, o sono, que deveria em estado normal ser saudável para o corpo, se trouxer consigo um sintoma negativo, como dor, é sinal de um adoecimento grave.

Apesar de o Corpus hippocraticum ser composto por uma grande variedade de textos, de autoria diversa ao longo de diferentes épocas, é possível, a partir das evidências textuais, ter algumas noções importantes acerca do sono e dos processos associados a ele. A ideia de que o sono tem um certo efeito no corpo, que geralmente se associa a uma das quatro Suvá $\mu 1 \varepsilon \zeta$ fundamentais, parece ser comum a todos. Não se vê nesses textos,

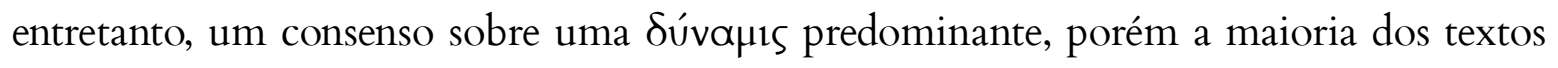
aponta para a primazia da umidade, pelo menos nos casos em que o normal é esperado. Nos casos em que se trata do patológico, porém, converge uma multiplicidade de ideias.

Essa noção, aliada à regra da moderação, presente em todo o Corpus hippocraticum, que indica que todo excesso resulta numa perturbação do equilíbrio do corpo — que, por outro lado é a base da saúde —, sustenta-se na ideia de que dormir ou estar acordado em demasia fazem mal, pois esses excessos alteram o equilíbrio corporal. 
Nas passagens citadas, há uma diversidade de teorias sobre o que acontece no corpo durante o sono - todas elas relacionadas às quatro Suvá $\mu 1 \varepsilon s$ fundamentais -, e explicam, em parte, como os diversos autores desses textos pensaram os mecanismos do sono. Para muitos deles, o calor é um fator importante, central para vários processos relativos à atividade do sono. Alguns exemplos são os movimentos de calor e frio no corpo, a importância do calor para a digestão e a dependência do sono em relação à quantidade de calor presente no corpo. Em segundo lugar em importância, a umidade, mencionada apenas por poucos autores, parece ser também responsável para a ocorrência do sono.

O sono, enquanto elemento indispensável da dieta, tem, assim como a alimentação e os exercícios, seu contraponto, que é dado pela desmedida - tanto para

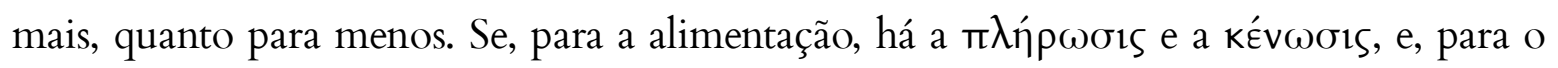
exercício, a inatividade e o róvos causado pelo excesso, para o sono há a insônia e a letargia. A insônia, entretanto, constitui uma impossibilidade, que é a de permitir uma interpretação de sintomas que estão para além do que é visível. Esses sintomas - esses

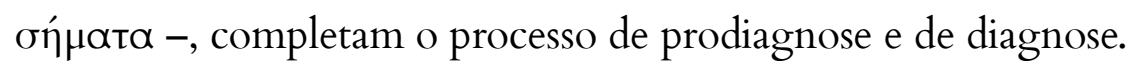




\section{O sonho na medicina hipocrática}

Este capítulo reúne algumas ocorrências de sonhos dentro do Corpus hippocraticum, com o fim de tentar situar o estatuto do conteúdo do livro IV do tratado Da dieta dentro do contexto maior da Coleção. Nos diversos textos, procurarei explicitar o lugar do elemento sonho, tanto no contexto do próprio tratado, quanto em contraposição a outros usos.

A única explicação completa sobre o assunto dos sonhos não se encontra no Corpus hippocraticum, senão que é oferecida posteriormente por Aristóteles no tratado Do sono e da vigília, no qual diz:

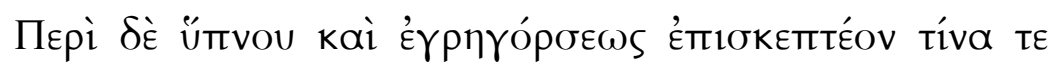

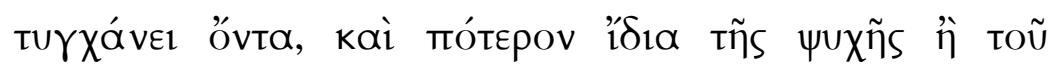

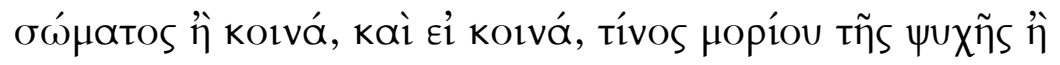

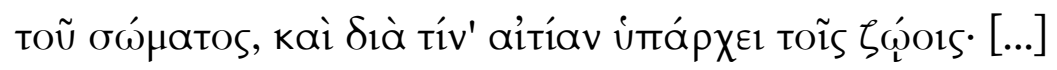

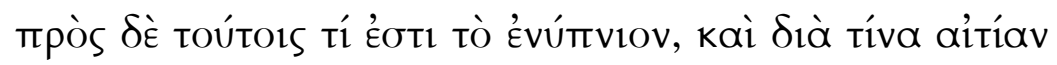

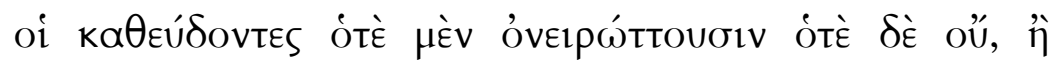

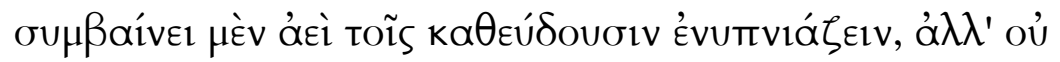

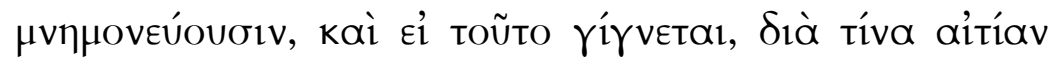
rírveta1.

Sobre o sono e a vigília deve-se investigar o que são, e se são particulares ou da alma ou do corpo ou comuns, e, se comuns, de qual parte da alma ou do corpo e por que causa vem a existir nos animais; [...] Além dessas coisas, o que é o sono e por que motivo os que dormem ora sonham, ora 
não, ou se acontece que sempre que os que dormem sonham, mas não se lembram, e, se isso acontece, por que motivo.

As condições materiais que favorecem o sono oferecidas por Aristóteles sobre o que acontece durante o sono e o que são os sonhos podem ser vistas não apenas nesse tratado, mas também em outros dos Parva Naturalia, a saber, Dos sonhos e Da divinação no sono. Nesses textos, o estagirita explica, grosso modo, que, após a chegada da comida no estômago, ela se difunde no sangue, evaporando-se pelo calor da barriga. Dali, o

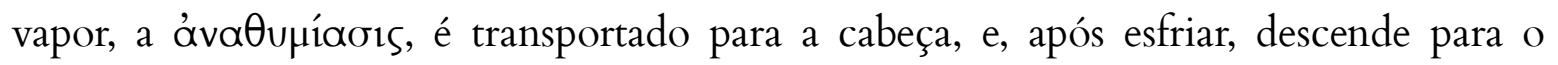
coração. No seu estudo a respeito do assunto, Holowchak reporta que "o sono traz consigo uma cessação da sensação e de algumas certas funções do coração, fazendo o sonho possível. Com os sentidos cessando, restos de sensação permanecem no sangue e, chegando no coração, são entendidos como sonhos." ${ }^{47} \mathrm{O}$ sonho, assim, tem origem na aîönoıs e é compreendido como tal:

kivoũvta1 $\delta$ '

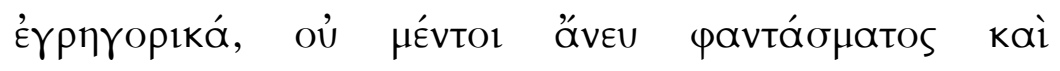

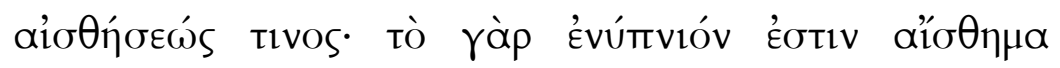

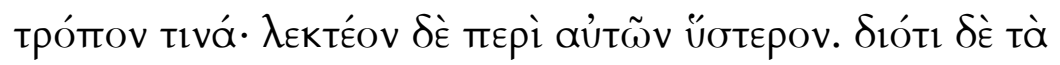

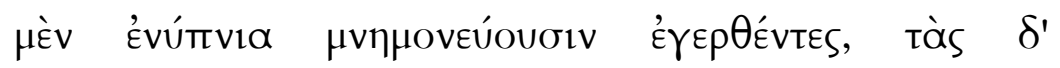

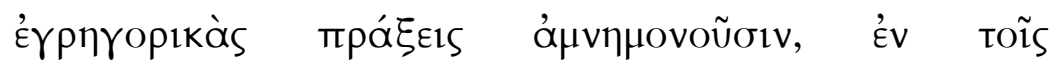

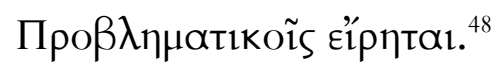

${ }^{47}$ Cf. Holowchak, M. "Aristotle on Dreaming: What Goes On in Sleep When the 'Big Fire' Goes Out". In: Ancient Philosophy 16, 2, 1996. pp.405-423.

48 Arist., Do sono e da vigília 456a 25-29 
Alguns se movimentam ao dormir e fazem muitas coisas como se estivessem acordados, entretanto, não sem uma imagem ou uma sensação. Pois o sonho é como se fosse uma sensação: falar-se-á sobre isso depois. Porque estando acordados se lembram dos sonhos, mas das ações durante a vigília não se lembram, foi enunciado nos Problemas.

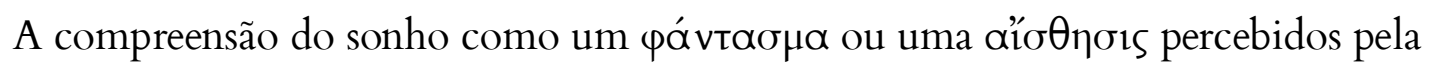
alma faz parte da teoria geral da percepção e são sub-temas do grande estudo aristotélico a respeito da alma. Galeno, séculos mais tarde, formula sua teoria sobre a alma e sobre o sonho, ecoando e ressignificando tanto as ideias do estagirita quanto as doutrinas da Escola hipocrática.

Há, entretanto, no Corpus hippocraticum, material que deve ser considerado para se pensar nos mecanismos dos sonhos, seja de maneira mais complexa e extensa, como é o caso do Da dieta, seja por breves comentários que revelem o lugar do sonho no pensamento de determinado autor.

O conhecimento do corpo e dos tratamentos pelo autor do Da dieta certamente incluem o conhecimento dos processos internos, principalmente a constituição da alma e seu modo de operar no corpo. Durante o sono, a alma acordada é responsável, autonomamente, pelas atividades do corpo. Ao estar esse acordado, aquela se divide e dá uma parte de si para cada faculdade; no momento do sono, sem o movimento e nem fatores externos que requeiram uso das faculdades sensitivas, ela realiza todas essas mesmas atividades:

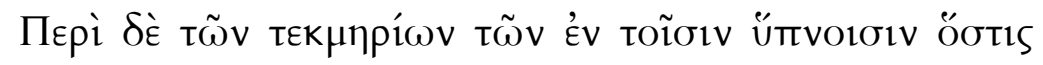

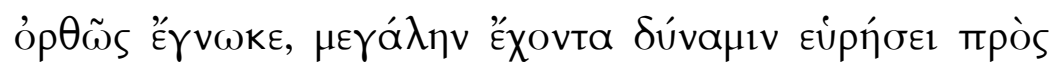




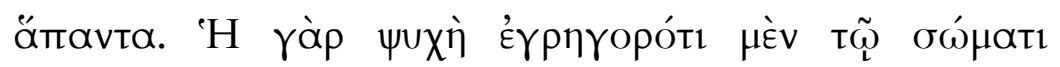

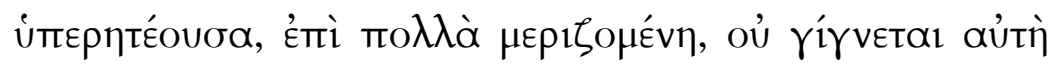

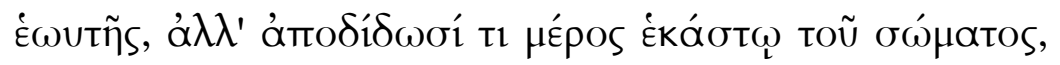

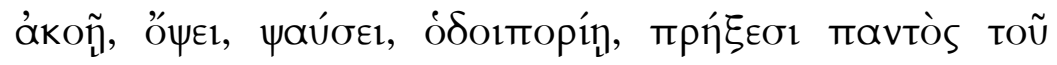

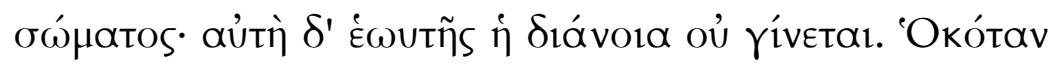

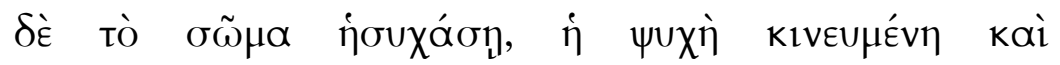

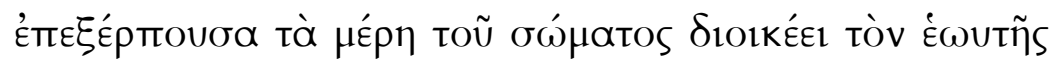

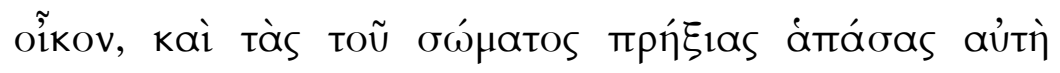

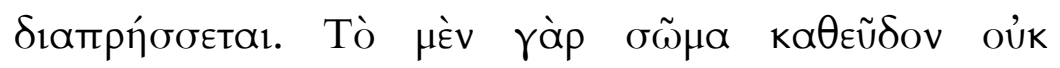

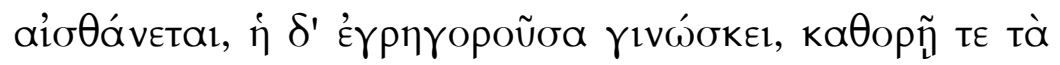

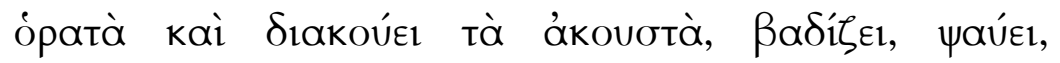

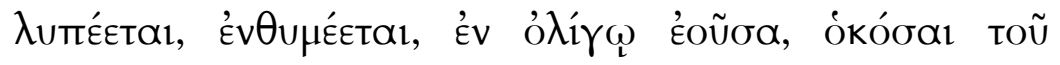

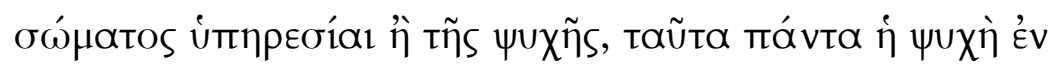

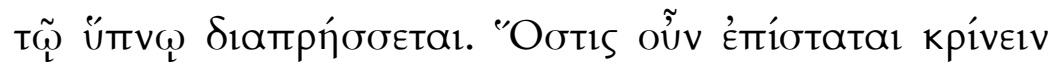

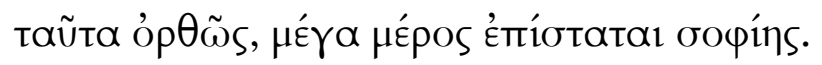

Sobre as evidências no sono quem aprendeu corretamente descobrirá que elas têm grande propriedade (força) sobre tudo por inteiro. Pois a alma, estando a serviço do corpo acordado, dividindo-se sobre muitas coisas, não é ela dela própria, mas dá uma parte a cada faculdade do corpo, à audição, à vista, ao tato, ao caminhar e às ações de todo o corpo; mas a mente nunca se torna dela por inteiro. Quando o corpo descansa, a alma, acordada e em movimento, administra sua própria casa e realiza ela mesma todas as atividades do corpo. Pois o corpo adormecido não sente, mas ela acordada conhece todas as coisas: vê o que é visível, ouve o que é audível, caminha, toca, sente dor, 
pondera; em uma palavra, todas as funções do corpo ou da alma, todas elas a alma realiza no sonho. Assim, quem sabe discerni-las corretamente, tem uma grande parte de sabedoria.

O sonho, assim, para o nosso autor, não é uma mera imagem, reflexo residual, ou imagem ou sensação do corpo quando acordado, como acreditado posteriormente por Aristóteles nos tratados que abordam o sonho, mas sim parte da ideia de que a alma tudo conhece, implicitamente deixando a đíônors de lado. Essa concepção de alma, por um lado materialista, sugere, por outro lado, uma relação com uma certa doutrina que pode aproximá-la daquela que Platão, posteriormente, desenvolve em algumas das suas obras, notadamente no Timeu.

No tratado Da dieta, os sonhos são apresentados como uma ferramenta de diagnóstico. Não todos os sonhos têm, entretanto, essa natureza. Alguns deles são proféticos e não diagnósticos. A origem dos sonhos diagnósticos é a alma, que, autônoma no sono, observa o corpo e 'alerta' se houver algum problema através dos sonhos. Se um médico souber interpretar tais sonhos corretamente, ele será capaz de formular uma prodiagnose, e, baseado nisso, adaptar a dieta do paciente de modo a prevenir uma doença. $\mathrm{Na}$ interpretação dos sonhos, o autor do $\mathrm{Da}$ dieta vê uma correlação entre as imagens oníricas representadas e o significado para quem sonha. No livro dos sonhos, vários princípios podem ser identificados, a saber: a semelhança com o real é bom, a dissemelhança é ruim; há uma certa analogia micro-macrocósmica entre o sonho e o seu significado; o sonho pode conter simbolismos; o sonho pode ser a satisfação de um desejo.

Há, entretanto, outros textos no Corpus hippocraticum além do Da dieta que mencionam os sonhos, e é possível tecer um panorama em que se possa ver um espectro 
maior do sonho na medicina. Em Epidemias VI, encontramos a noção de autonomia da alma durante o sono:

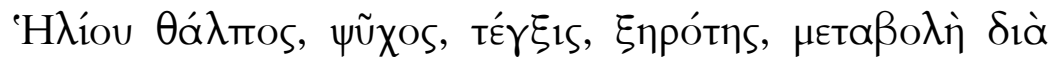

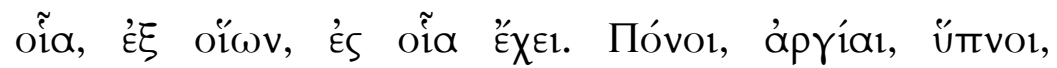

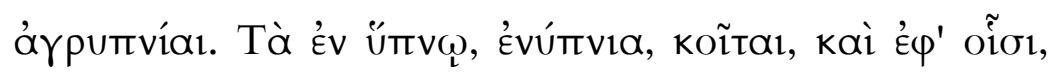

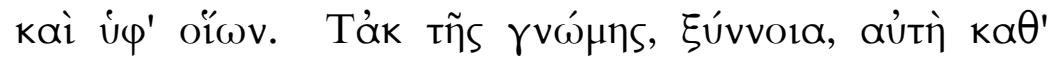

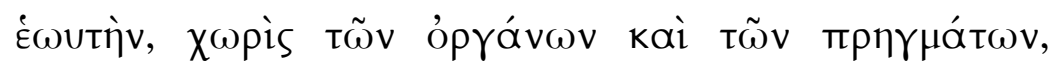

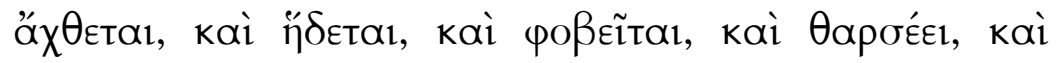

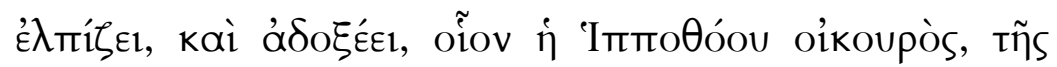

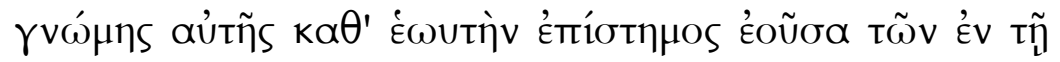

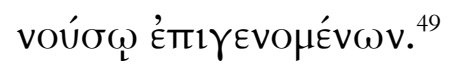

O calor do sol, o frio, a umidade, a sequidão; há mudança através deles, a partir deles e para eles. Esforços, inatividade, sonos, insônias. O que há nos sonos, os sonhos, leitos, tanto neles quanto por causa deles ${ }^{50}$. E o que há no juízo, angústia, ela por si só, independente dos órgãos e das ações, é conduzida, e tem prazer e sente medo, tem coragem e tem esperança e desdém, como a serva de Hipótoo, que, a partir do seu juízo, por si só, é conhecedora do que sobrevém na doença. ${ }^{51}$

\footnotetext{
${ }^{49}$ Epid VI, 8, 9

50 Optamos por essa tradução ao invés do sentido mais físico "neles e sob eles"

${ }^{51}$ Este excerto tem uma sintaxe peculiar, anacolútica, cujas construções resultam em um desafio para os tradutores. García Novo (1989:246) soluciona os problemas apresentados por essas estruturas com reticências, que indicam inevocadamente a convicção dessa tradutora de que há, no próprio texto, algo que fere sua coesão. No entanto, cônscia de que Émile Littré resiste ao reconhecimento de lacunas e anacolutos, pareceu-me coerente e sensata sua busca por uma sintaxe plena dos períodos do trecho. Sem seguir aqui exatamente a trilha de Littré, encontrei lugar como genitivo de origem para tĩs $\gamma v \omega ́ \mu \eta \varsigma$

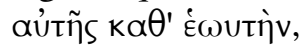




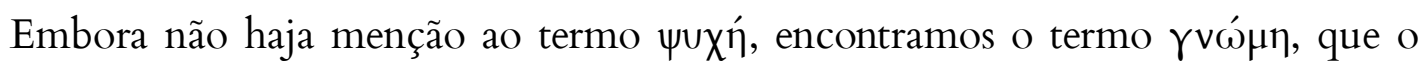
próprio Galeno, no seu comentário ao texto ${ }^{52}$, associa à alma. Da mesma forma que em Da dieta IV, 87, observa-se a indicação de uma observação independente do corpo e sua condição durante o sono pela $\gamma v \omega ́ \mu \eta$, que tem um lugar autônomo no corpo. No mesmo texto de Epidemias VI, encontramos outra passagem que reitera essa noção:

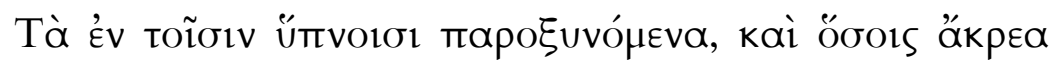

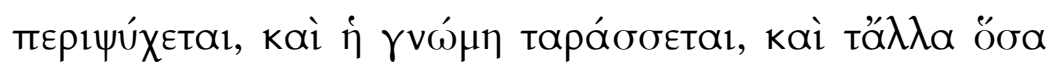
$\pi \varepsilon p \grave{i}$ ürtvov tolaũTa, kaì oĩo1 tỏvavtía. ${ }^{53}$

[Há] as [doenças] exacerbadas durante o sono, e nas quais as extremidades se esfriam e também o juízo se perturba, e [há] as outras da mesma forma em relação ao sono e nas que [acontece] o contrário.

O autor, aqui, menciona uma série de sintomas que ocorrem no sono, entre eles o esfriamento das extremidades e a perturbação da $\gamma v \omega ́ \mu \eta^{54}$. O sintagma Tà Év toĩoıv

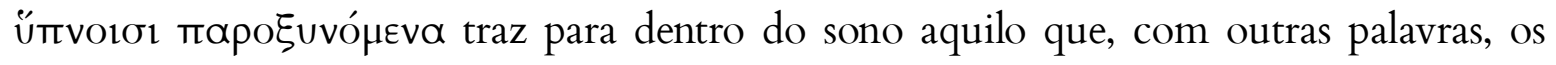
Aforismos II, 1-3, já abordados no capítulo anterior desta Tese, creditam ao sono em si (sem a preposição év). Ou seja, esta passagem do Epidemias VI dá ao sonho o que aqueles aforismos atribuíam ao sono. Littré (V, p.345), no entanto, talvez num esforço peculiar de homogeneização do Corpus hippocraticum, parece postular a equivalência do pensamento nas duas passagens.

\footnotetext{
${ }^{52}$ Cf. In Hip. Epid. VI. 8

${ }^{53}$ Epid. VI, 8, 5

${ }^{54}$ Cf. Manetti e Roselli, 1982, p. 165.
} 
Esse texto parece evocar as ideias de Empédocles (31 A 85 DK), que sustentava que o sono esfria os corpos e favorece a presença dos sonhos ${ }^{55}$ :

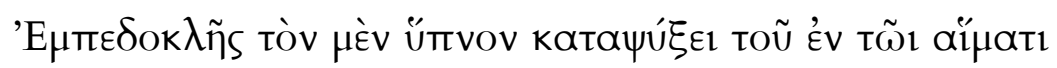

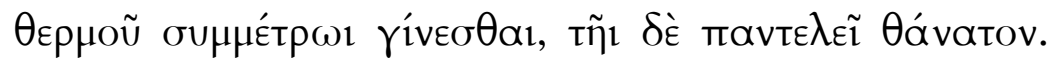
$A$ ËT. V 24, 2 (D. 435)

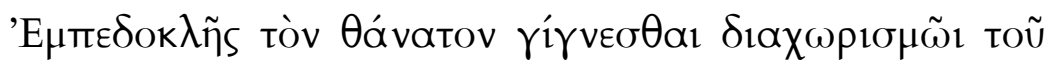

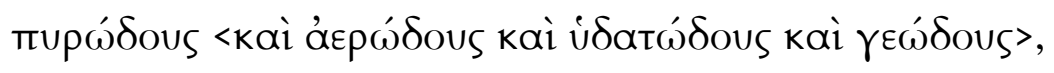

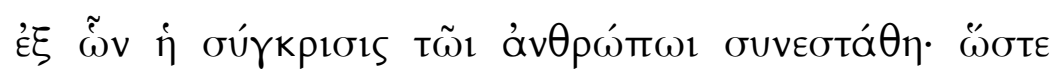

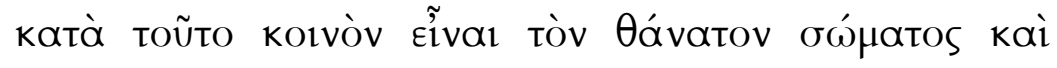

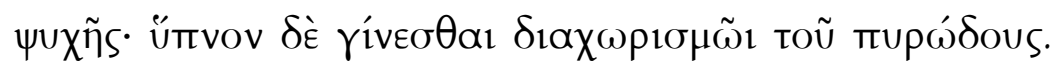
ÈCIO. V 25, 4 (D. 437)

Empédocles [afirma que] o sono ocorre por causa de um resfriamento equilibrado do calor no sangue, e a morte, [um resfriamento] completo.

Empédocles [afirma que] a morte ocorre por uma separação do ígneo <e do aéreo, do aquoso e do térreo>, a partir dos quais se junta a composição do homem; assim, de acordo com isso, a morte do corpo e da alma é algo comum; e o sono ocorre por uma separação do ígneo.

A relação entre o sono e o resfriamento parece ter sido uma ideia comum entre os physiológoi. Além de Empédocles, encontramos a ideia do sono atrelado ao frio em Parmênides (28 A 46b DK) e em Diógenes de Apolônia (64 A 29 DK). A respeito da

\footnotetext{
${ }^{55}$ Marelli (1981, p.331-339) não considera que haja uma influência direta de Empédocles no texto, pelo menos a respeito da relação direta do sonho com o frio, porém ressalta que o eco se dá na questão do sangue como condutor do pensamento.
} 
relação do sono com a morte, Marelli ${ }^{56}$ explica que tal processo, para esses autores, tem fundo etiológico:

Le processus qui explique l'apparition reste dans les limites d'une tolérance organique qui garantit sa réversibilité. On ajoutera que ces explications physiologiques sont accompagnées parfois par des aspects plus franchement psychologiques qui présentent l'état de sommeil comme degré réduit de la faculté intellective (comparable à l'ivresse et à la répletion d'aliments $[. .$.$] ou plus précisément de la$ capacité mnémonique.

No tratado Doença Sagrada, podemos encontrar uma explicação fisiológica para a ocorrência de medos e ansiedades durante o sono, bem como um especial interesse nos sonhos que o perturbam. No capítulo 14, o autor aponta o cérebro como a origem dos prazeres e medos, mas também o órgão é responsável pelo pensamento, percepção e pela formação de opinião. Se, no entanto, o cérebro sofrer alguma coisa, como aquecimento, esfriamento, ressecamento ou umedecimento, ou se passa para uma condição diferente do seu estado habitual, isso pode resultar em delírio, loucura, entre outros:

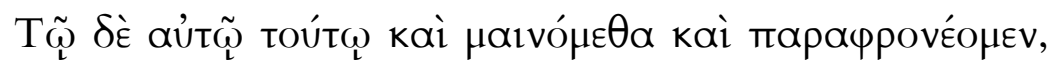

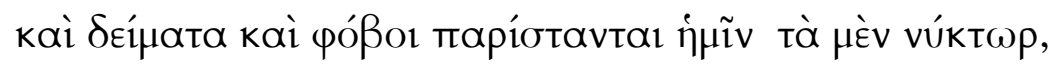

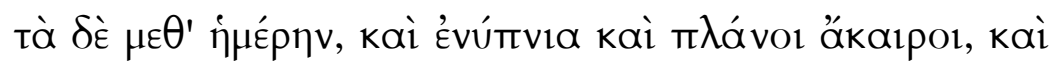

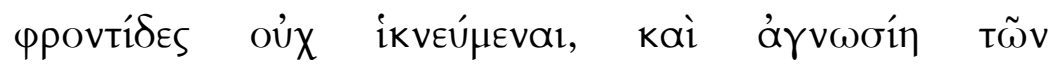

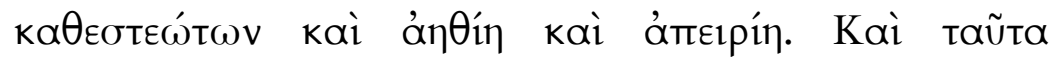

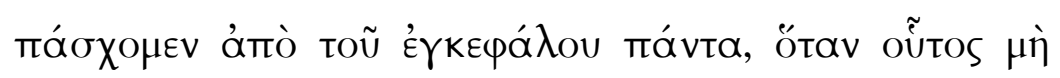

56 1983, p.332 


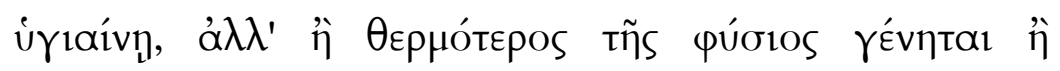

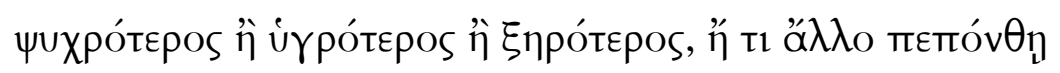

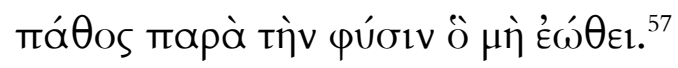

É também através dele (o cérebro) que enlouquecemos e deliramos, e nos vêm os terrores, os medos, alguns durante a noite, outros durante o dia, e os sonhos, os erros inoportunos, as preocupações inconvenientes, a ignorância do estabelecido, a falta de costume e a inexperiência. De tudo isso somos passíveis a partir do cérebro, quando este não está saudável, porém torna-se mais quente do que sua natureza, ou mais frio, ou mais úmido, ou mais seco, ou sofre, contra a natureza, outra afecção que lhe é inabitual. ${ }^{58}$

O autor continua por explicar os efeitos de um cérebro com muita umidade.

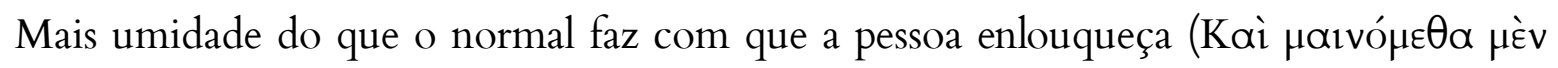

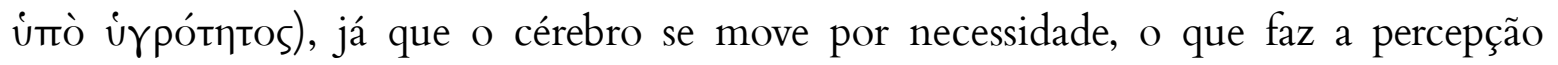
instável. É só quando o cérebro fica parado que o homem está consciente. As explicações do autor a respeito da loucura aparecem no capítulo 15, cujas causas o autor atribui ao aquecimento ou resfriamento do cérebro. $\mathrm{O}$ aquecimento do cérebro ocorre, segundo ele, pelo excesso de sangue que corre pelas vias sanguíneas e ali ferve. Isso acontece quando a pessoa tem um sonho aterrorizante. Como paralelo, o autor explica que isso é o mesmo que acontece quando, acordado, o rosto se esquenta e os olhos enrubescem ao sentir medo, e a $\gamma \vee \omega ́ \mu \eta$ tem conhecimento de que algo ruim ocorreu:

\footnotetext{
${ }^{57}$ DS, $14,10-15$

${ }^{58}$ Trad. H.F. Cairus, 2005, p.76
} 


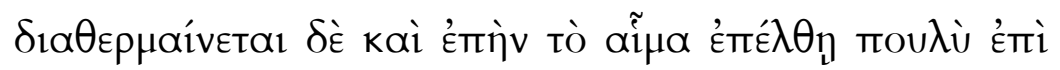

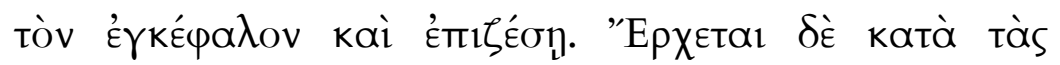

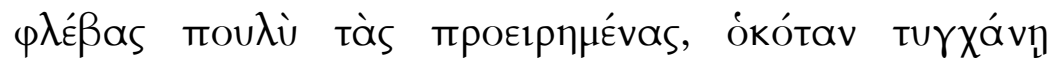

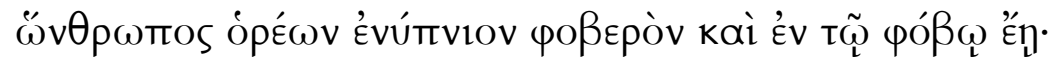


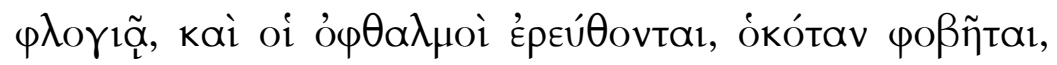

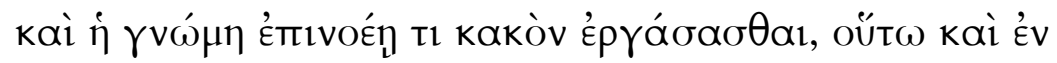

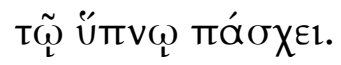

$\mathrm{O}$ indivíduo se esquenta quando o sangue abundante chega ao cérebro e ferve; depois, segue abundantemente, através das veias mencionadas, quando então o homem tem um sonho apavorante e mantém-se amedrontado. De sorte que, ao acordar, o rosto põe-se mais ardente e os olhos se envermelhecem, quando ele tem medo, e o juízo concebe realizar algo ruim, o mesmo lhe ocorrerá no sono. ${ }^{59}$

Para o autor de Doença Sagrada, o sonho apenas parece ter importância médica quando aponta uma perturbação no sono por pesadelos, uma vez que, nesses casos, o médico pode inferir a respeito da condição do cérebro e dos tipos de humores e propriedades que ali atuam. O que também deve ser levado em consideração é a natureza do tratado, uma vez que o foco do autor não se encontra no diagnóstico, mas sim numa possível etiologia da doença. Talvez isso explique a falta de interesse no sonho enquanto possível ferramenta diagnóstica.

${ }^{59}$ idem, p.77 
Diferente dos textos vistos até agora, em que o sonho aparece citado apenas enquanto processo, sendo ignorado o seu conteúdo, o tratado Humores 4 menciona os “sonhos que se veem” ('Evútrvia oĩa ồv ópén) como parte de uma lista de sintomas. Não

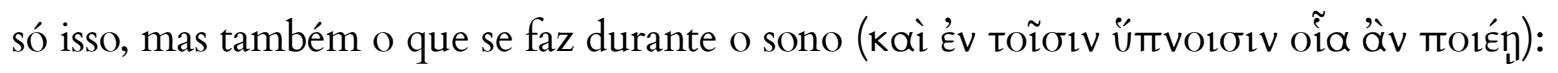

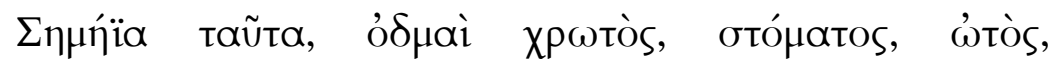

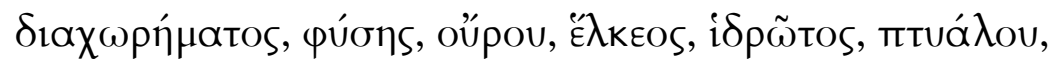

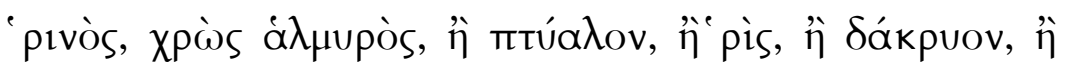

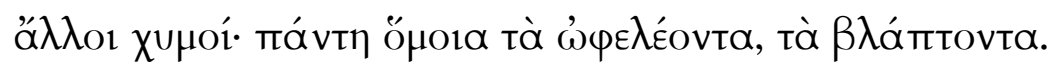

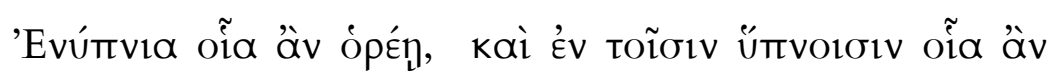

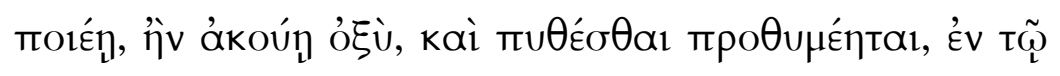

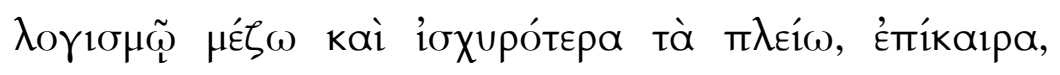

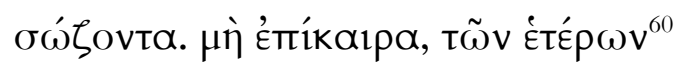

Sinais são estes, odores de pele, de boca, de ouvido, das evacuações, dos flatos, da urina, da ferida, do suor, da saliva, do nariz, pele salgada, ou saliva, ou nariz, ou lágrimas ou outros humores. É em tudo semelhante o que beneficia e o que prejudica. Os sonhos que se veem, o que se faz durante os sonos, se se ouve com acuidade e se se deseja aprender, no conjunto, é melhor e mais forte o que for mais numeroso, se oportuno, é salvífico. Se não oportuno, é de outras [naturezas].

No tratado Dos flatos, o autor associa a presença do frio pelo processo do

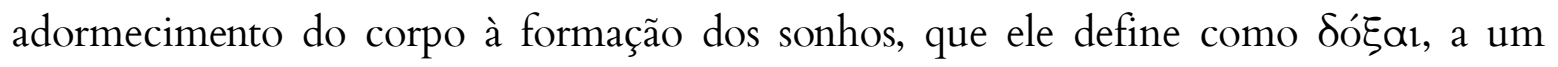

${ }^{60}$ Humores, 4 
certo modo platônico avant la lettre. ${ }^{61}$ Este trecho do tratado Dos flatos consiste, de resto, na mais clara definição de sonho encontrada no Corpus hippocraticum, ainda que tal definição tenha formato descritivo. A frase que encerra essa descrição é que, contudo, the dá o caráter de glosa conceitual:

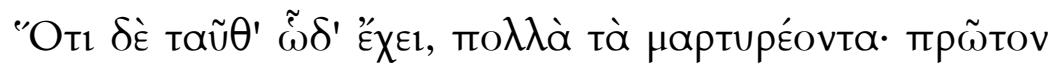

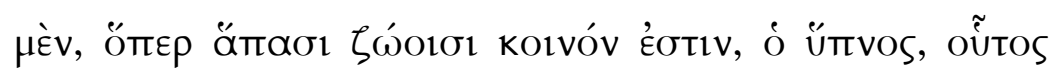

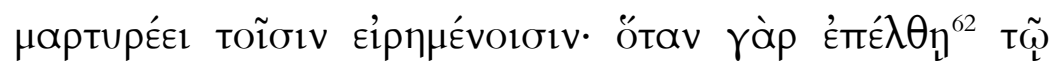

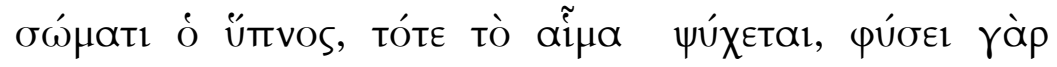

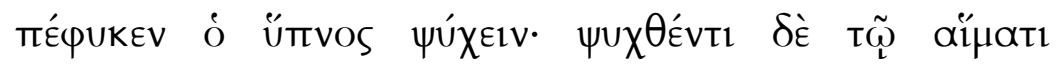

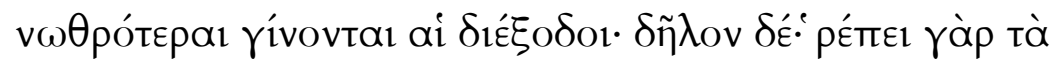

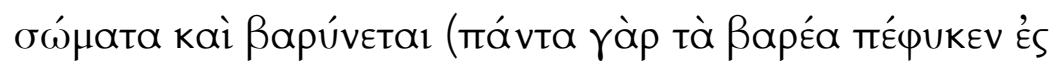

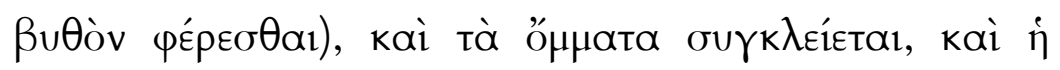

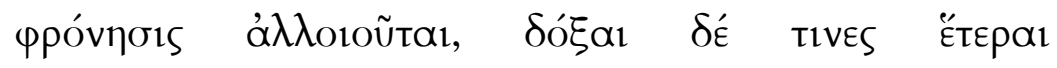

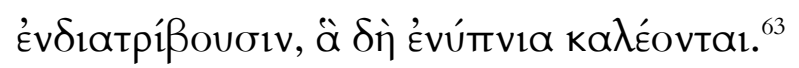

De que isso é assim (que o sangue contribui para a inteligência), muito há que testemunhe: primeiro, o que é comum a todos os animais, o sono, o qual testemunha por aquilo que foi dito. Quando o sono sobrevém ao corpo, então o sangue esfria, pois o sono por natureza tende ${ }^{64} \mathrm{a}$ esfriar. Pelo sangue esfriado, os circuitos se tornam mais lentos. É evidente: pois os corpos se inclinam e pesam (pois tudo o que é pesado tende a levar ao fundo), os olhos se

61 As definições de sonho serão exploradas mais à frente neste capítulo.

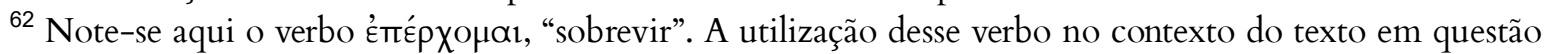

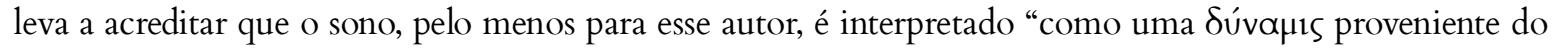
exterior, à maneira homérica" (López Férez, 2008, p.146).

${ }^{63}$ Dos flatos, 14.

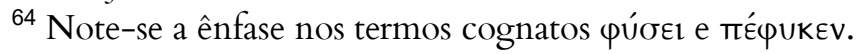


fecham e a inteligência se altera, e umas outras visões ${ }^{65}$ se estabelecem, é o que chamam de sonhos.

Nesse texto, a discussão do processo do sonho decorre de uma explicação maior a respeito da "doença chamada sagrada" ${ }^{66}$. O autor expõe que o sangue, de todos os

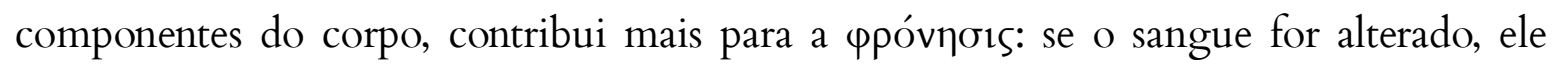
explica, isso tem um efeito imediato na ppóvๆors. Para provar isso, ele evoca o exemplo do que acontece durante o sono. O sono é conhecido pelo seu efeito de esfriar. Quando o sono vem, o sangue esfria, e, como resultado, a passagem fica lenta. Isso fica claro pelo fato de o corpo ficar pesado e os olhos fecharem. Por ter ocorrido uma alteração no sangue, também ocorre uma alteração na ppóvฤors.

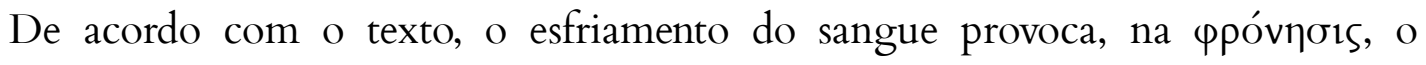
surgimento de $\delta$ ó́ $\alpha_{1}$, ou, melhor, de sonhos. Os sonhos constituem um fenômeno inerente ao processo do sono, e sua ocorrência não configura em si uma anormalidade. Entretanto, além do resfriamento do sono, o autor explica que há outro fator que pode

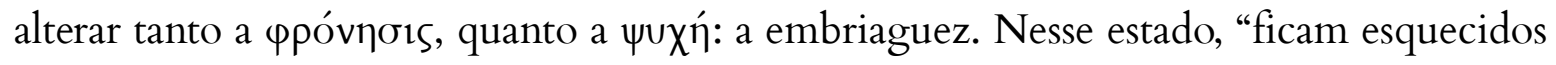

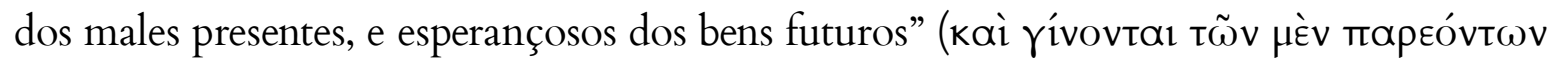

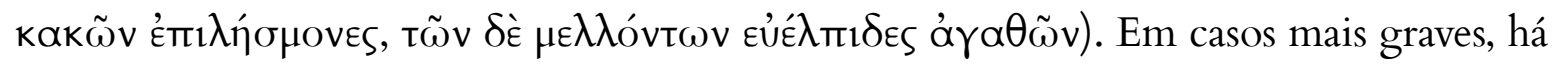
apagamento completo da ppóvnors. Parece, para o autor, haver a ideia de que quanto mais afastados de qualquer condição que ele reconheça como natural, tanto mais os processos intelectivos são afetados, ao ponto de desaparecerem totalmente.

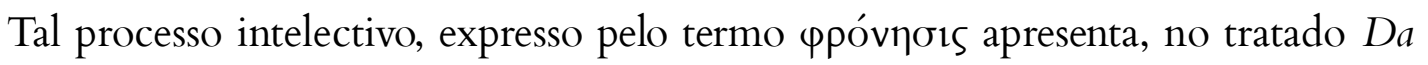
dieta uma longa discussão em relação ao seu lugar na $\psi v \chi \eta$, no capítulo 35. O tratadista,

\footnotetext{
${ }^{65}$ Trata-se aqui do termo $\delta o ́ \xi \alpha$, que pela tradição fora traduzido por "razão" (Vernunft) e considerado como sinônimo de đíoӨnoıs, por F. Hüffmeier (apud López Férez \& García Novo, 2008, p. 145-146, infra), talvez como uma leitura aristotélica, e traduzido tanto por López Férez quanto por Jones como "inteligência".

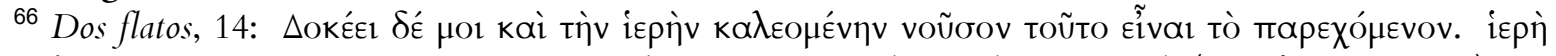

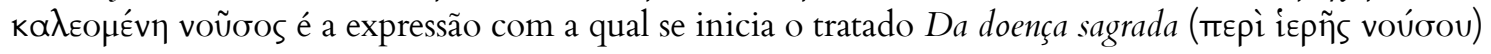




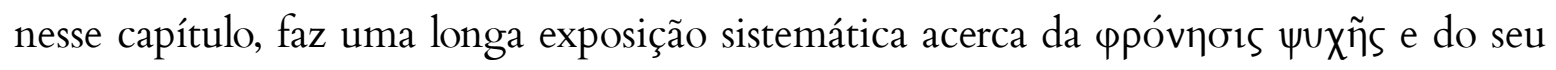

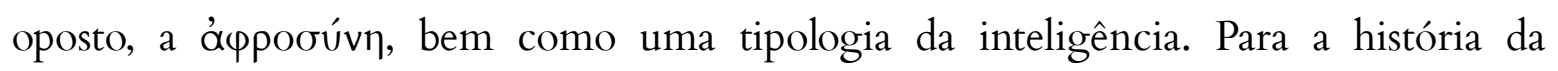
psicologia, esse é um documento importantíssimo, uma vez que é uma das raras teorias pré-platônicas a respeito da alma de que se tem registro. Sobre esse assunto, o capítulo seguinte procurará expor. 


\section{A alma no Da dieta}

Antes de examinar o conteúdo do livro IV do tratado Da dieta em si, é necessário investigar sobre a definição de alma que o autor oferece no mesmo tratado, bem como as relações intertextuais com autores coevos. Além das explicações fisiológicas a respeito da formação da alma, das quais se destaca o esquema de três circuitos vasculares essenciais para os processos de geração do corpo humano, o tratadista oferece, da mesma forma e com igual importância, uma descrição macrocósmica aliada a eles, em que todos os processos biológicos revelam-se como uma imitação, ou uma projeção, do todo

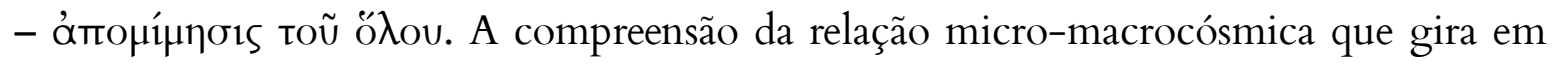
torno do conceito de ámopífпors funciona como chave para compreender tanto a mecânica do corpo quanto a semiologia dos sonhos.

Exige atenção, no tratado $D a$ dieta, a frequência excepcional do termo $u v x \mathfrak{\eta}$, quando comparado a outros tratados coevos. Tal frequência se relaciona evidentemente à doutrina do autor e aos temas que ele desenvolve, principalmente ao final do tratado, quando versa sobre o sonho, produto exclusivo da $\psi v \chi \mathfrak{x}$. Joly aponta que as copiosas ocorrências do termo funcionam como um critério de datação; porém, como contraponto, cita uma série de evidências em outros textos que contrariariam tal hipótese:

Comme cette fréquence a parfois paru un indice pour situer l'oeuvre au milieu du quatrième siècle, je rappelle que, sans développer toute une anthropologie comme le Régime, le traité Des airs, eaux, lieux utilise cinq fois le mot чuхฑ́, Epidémies VI, trois fois, Humeurs, trois fois, Vents, deux fois. Le terme se trouve aussi une fois en Articulations, en Nature de l'homme, en Affections, en Prorrhétique II. 


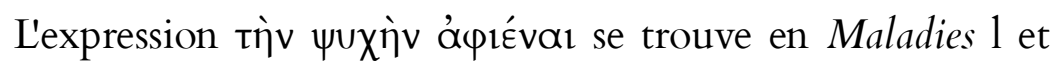
quatre fois en Affections internes. ${ }^{67}$

\subsection{A alma como orép $\mu \alpha$}

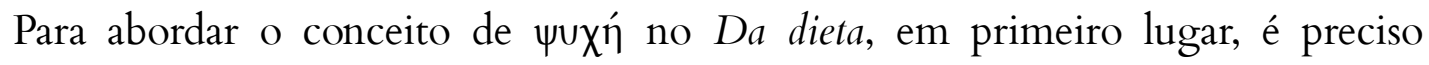
considerar que, para o tratadista, a alma consiste de uma mistura entre fogo e água, os mesmos componentes que formam a vida de todos os animais. Essa concepção,

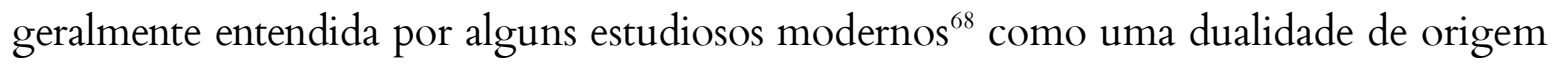
órfico-pitagórica, e que se emparelha àquela que coloca corpo e alma em oposição um ao outro, introduz a ideia de alma como semente:

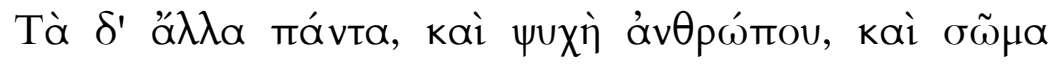

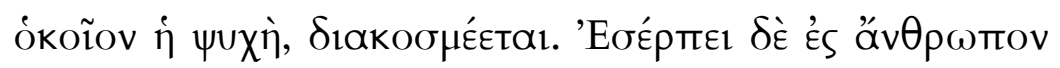

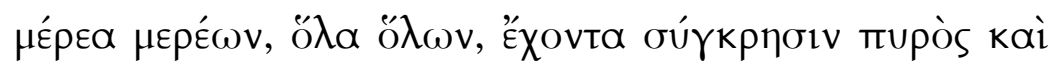

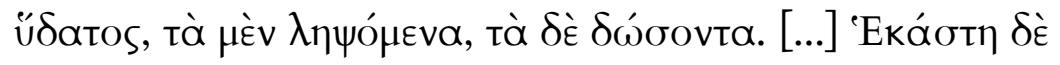

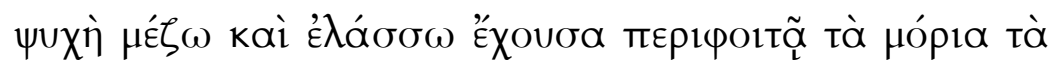

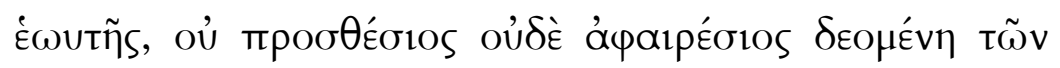

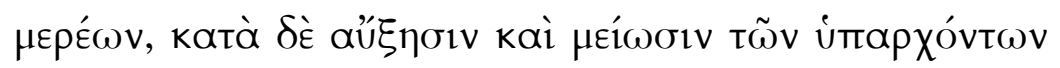

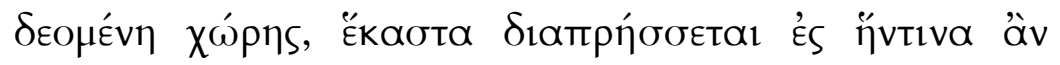

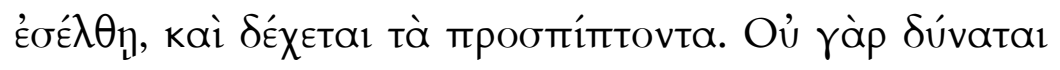

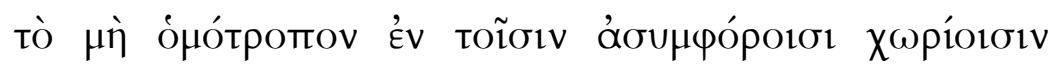

\footnotetext{
${ }^{67}$ Joly \& Byl, 1984, p. 237.

${ }^{68}$ Em especial, Jones (1931, XLIII n.3), que aponta o uso do par fogo-água como o principal indício. Essa questão sobre a influência órfica-pitagórica no Da dieta é abordada por Hynek Bartos no seu artigo "Seed, soul and palingenesis in the hippocratic De victu", em que se explora uma possível ideia de transmigração e imortalidade da alma nesse tratado.
} 


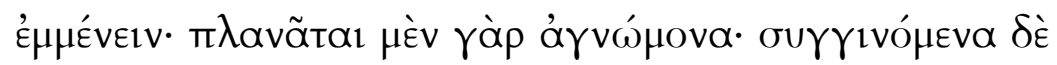

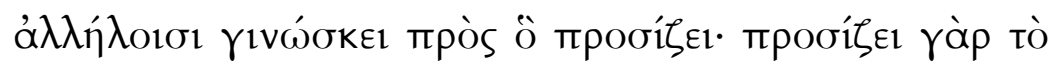

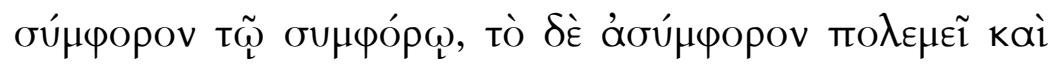

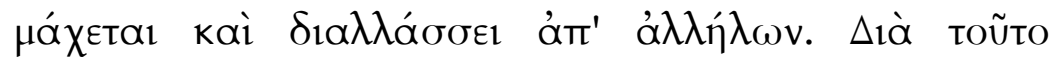

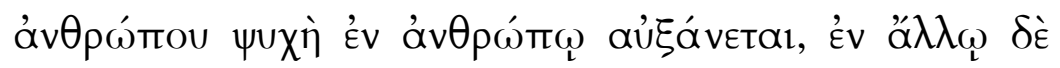

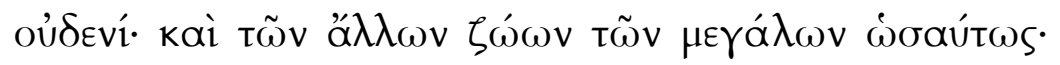

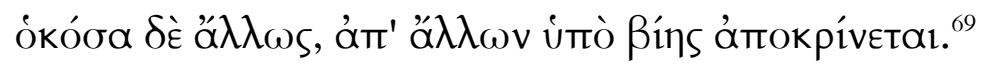

Todas as outras coisas são organizadas, tanto a alma do homem quanto o corpo do mesmo jeito que a alma. Entram, pois, no homem, partes de partes, um todo do todo, que tem uma mistura de fogo e de água, umas que receberão e outras que darão. [...] Cada alma, tendo partes maiores e menores, perambula pelas suas próprias partes, não carecendo de aumento ou de separação das partes, mas carecendo de espaço de acordo com o aumento ou atrofiamento do que existe, realizará cada coisa que lhe couber, e recebe o que lhe sobrecai. Pois o não que não tem o mesmo comportamento não pode ficar nos espaços não apropriados; pois enquanto vagam sem saber, juntando-se umas às outras, sabem com o que juntam. Pois junta-se o conveniente ao conveniente e o inconveniente guerreia, luta e diverge mutuamente. Por isso, a alma do homem aumenta no homem, mas não em nenhum outro; e a dos outros animais grandes é da mesma forma; e os que são de maneira diferente, separam-se dos outros à força.

\footnotetext{
${ }^{69}$ Da dieta, 6.
} 
Segundo Joly ${ }^{70}$, esse capítulo é obscuro e poucos comentadores se arriscaram a explicá-lo a fundo. Considerando que os capítulos seguintes versam sobre a embriologia, Joly propõe que o primeiro caminho de interpretá-lo seria como uma introdução ao

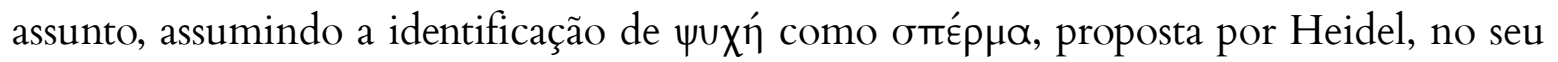
artigo "Hippocratea l", publicado na Harvard Studies in Classical Philology 25, de 1924. Entretanto, propõe um segundo caminho de interpretação, considerando que "não há nada propriamente embriológico neste capítulo" ${ }^{\text {, }}$, seguindo a hipótese de Müller $^{72}$, que vê ali o início de uma explicação a respeito da natureza específica do homem. De fato, no capítulo 7, o autor do Da dieta distingue o homem de todos os outros animais pela presença da alma no corpo, uma vez que a alma neles não se pode desenvolver, pois não haveria espaço para o seu crescimento:

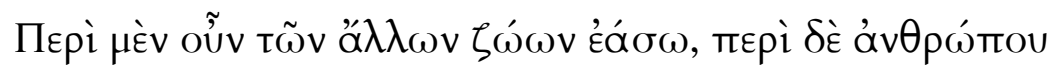

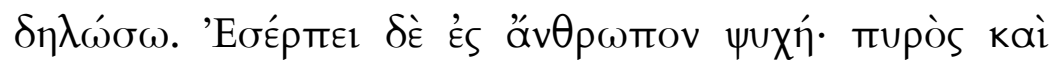

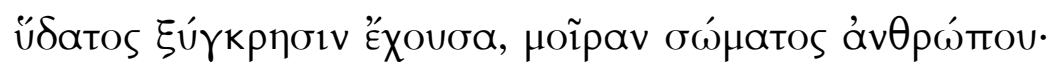

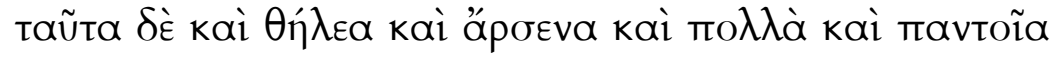

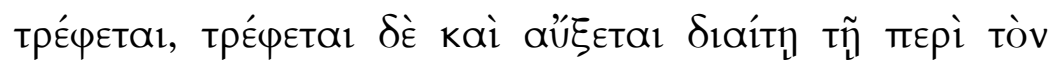

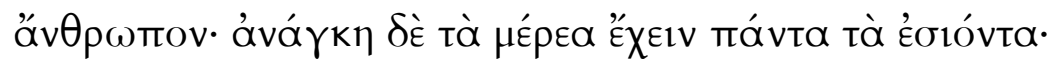

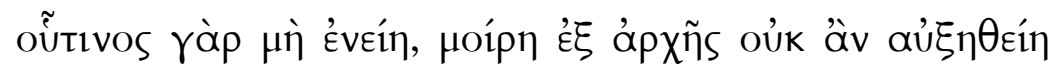

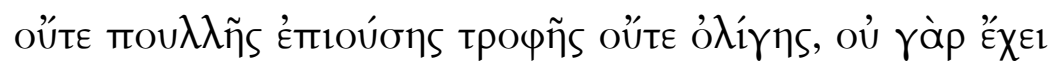

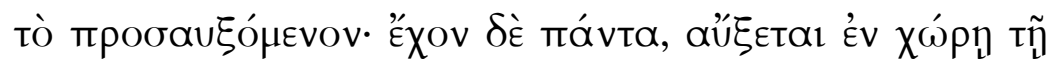

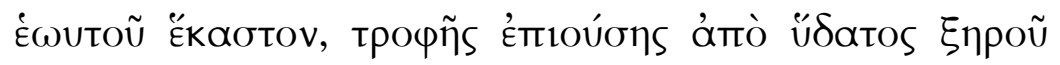

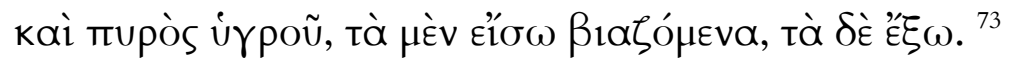

\footnotetext{
${ }^{70}$ Joly \& Byl, 1984, p. 238.

${ }^{71}$ Cf. também Joly \& Byl, 1984, p. 30.

${ }^{72}$ Müller, C. W. G1eiches zu Gleichem. Ein Prinzip frühgriechischen Denkens, Klassisch-Philologische Studien, 31, Wiesbaden, 1965. Apud Joly \& Byl, 1984.

${ }^{73}$ Da dieta, I, 7
} 
Acerca dos outros animais deixarei de falar e acerca do homem farei uma exposição. Entra no corpo uma alma, que é mistura de fogo e água, parte do corpo humano. Essas partes, tanto femininas quanto masculinas, são muitas e nutrem muitas formas; nutrem-se e crescem por meio da dieta do homem. É necessário que tudo o que entra tenha partes, pois se não tiver nenhuma, não poderia crescer nenhuma, nem de muita nutrição recebida, nem de pouca, pois não haveria o que crescer. Tendo todas as partes, cresce no espaço que lhe é próprio, recebendo nutrição da água seca e do fogo úmido, sendo umas forçadas para dentro e outras, para fora.

No início do capítulo 25, encontramos estrutura e vocábulo semelhantes aos capítulos 6 e 7. O dado que é introduzido neste capítulo, no entanto, é a possibilidade de, no corpo, serem nutridas muitas almas. Aqui é reforçada a ideia, já delineada no capítulo 6, da alma enquanto semente, que entra no corpo ao mesmo tempo em que as partes do corpo em si. A diferença do homem em relação aos outros animais é a possibilidade de crescimento e nutrição, dada não só pelo espaço físico, mas também por

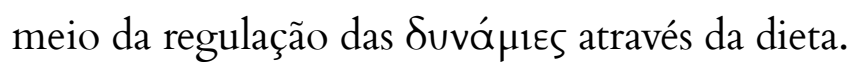

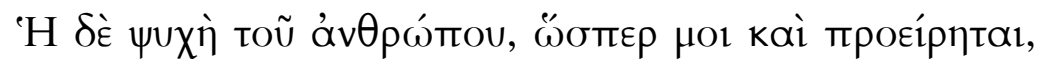

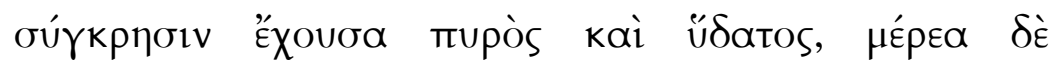

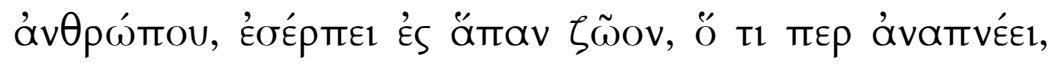

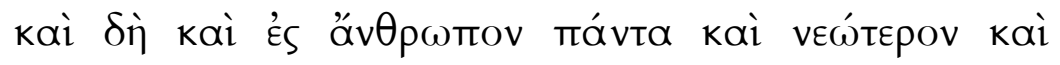

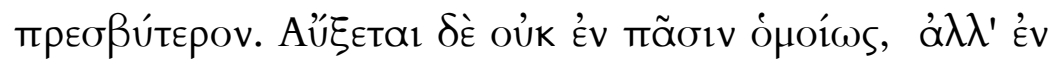




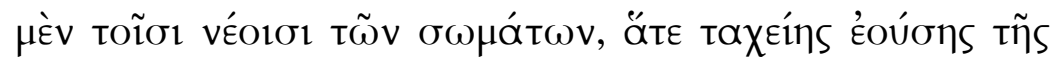

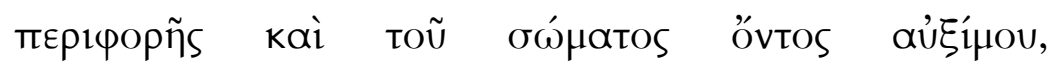

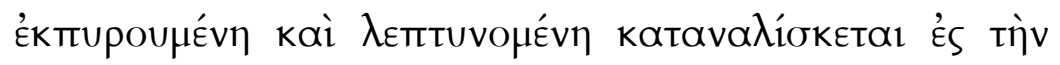

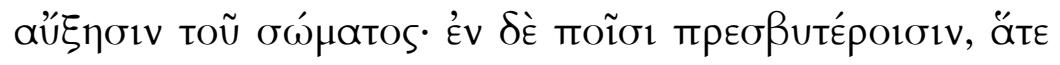

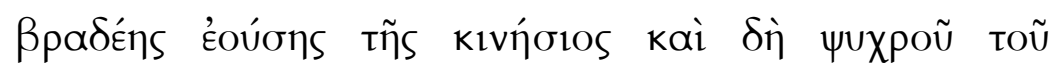

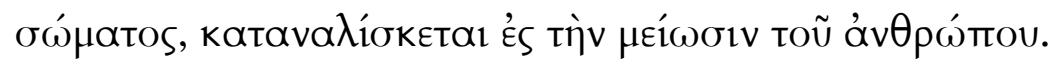

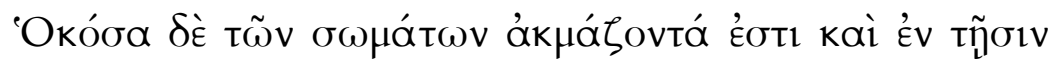

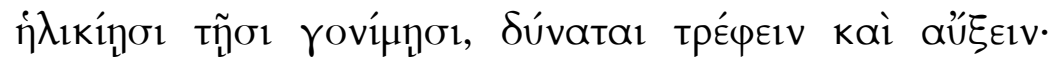

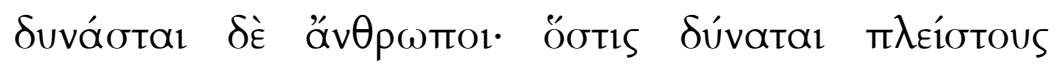

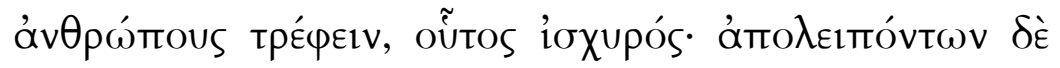

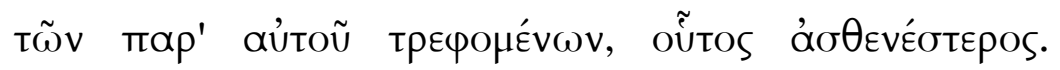

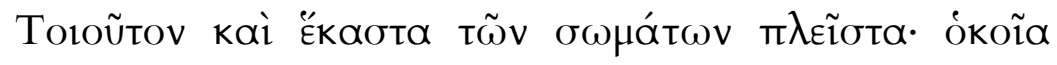

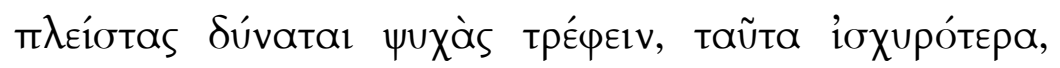

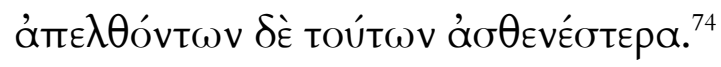

A alma do homem, como já foi dito por mim, sendo uma mistura de fogo e água, partes do homem, entra em todo animal, porquanto respira, e certamente em todo homem, tanto mais jovem quanto mais velho. Mas não cresce em todos da mesma forma. Mas, nos mais jovens dos corpos, os quais, sendo o circuito mais rápido e o corpo estando em crescimento, consome queimando e tornando-o leve para o crescimento do corpo. Nos mais velhos, os quais, sendo o movimento lento, e sendo o corpo frio, consome para o atrofiamento do corpo. Aqueles entre os corpos que estão na plenitude e nas idades de procriação, podem nutrir e fazer crescer. [Como] os homens poderosos, que podem

\footnotetext{
${ }^{74}$ Da dieta, 1, 25
} 
nutrir muitos homens, esses são fortes; eles os abandonando, ficam mais fracos. Assim também é com cada um dos corpos. Os que podem nutrir muitas almas, esses são mais fortes, e mais fracos quando essas os abandonan.

Mais adiante, o autor introduz a formação dos tipos de sementes - masculinas e femininas - e explica que é possível alterá-las por meio da dieta, considerando que ambas são uma mistura de fogo e água ${ }^{75}$, e também considerando a sua tipologia, que associa o gênero masculino ao fogo e o feminino à água. O desenvolvimento da semente masculina ou feminina, assim, dependerá de uma dieta mais quente e seca ou mais fria e úmida, como mais adiante, nos capítulos 26 e 27, é explicado. Ali, o tratadista expõe que os seres se desenvolvem de maneira diferente, dependendo de cada natureza e das condições em que são gerados, sempre em função das predominâncias das Suvápies próprias de cada corpo que os gera. Entretanto, no capítulo 28, o tratadista deixa claro que, na semente, há uma parte mutável e outra imutável; essa última é a alma:

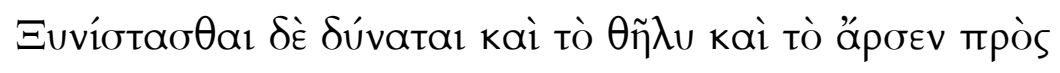

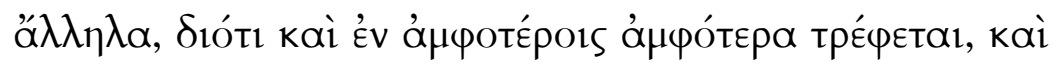

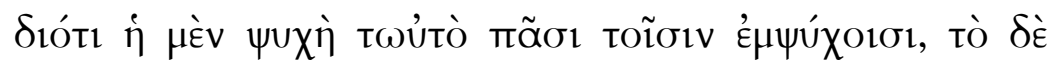

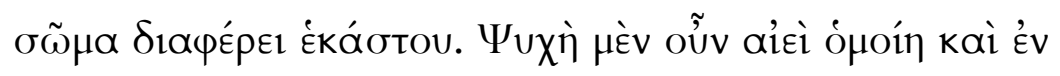

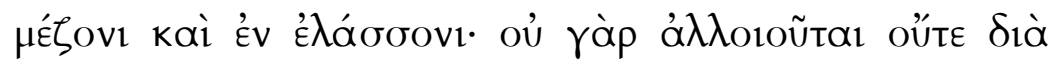

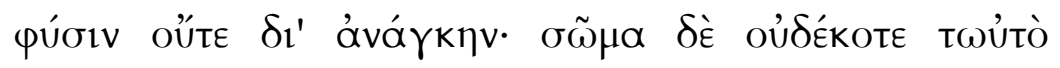

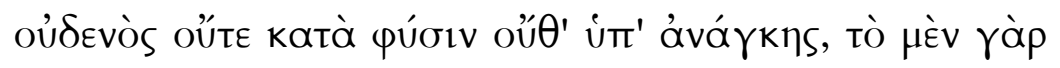

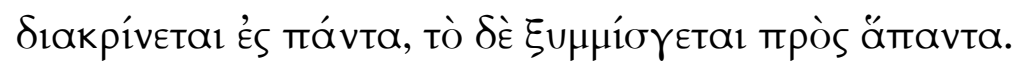

\footnotetext{
${ }^{75}$ Vide Cap.10 do livro 1, explorado mais adiante neste capitulo.
} 
Podem fundir-se mutuamente feminino e masculino, porque em ambos se nutrem ambas as coisas, e porque a alma é o mesmo para todos providos de alma, mas o corpo de cada um diferencia-se. Logo, a alma sempre é semelhante, tanto no que é maior quanto no que é menor, pois não se altera nem por natureza nem por necessidade; mas o corpo de ninguém jamais é o mesmo nem conforme a natureza, nem sob a ação da necessidade, pois ora se distingue de tudo, ora se mistura com tudo. ${ }^{76}$

A partir daqui, é possível compreender por que essa distinção tenha sido interpretada por alguns comentadores como uma dualidade; entretanto, parece-me claro que ali, embora o autor implique uma distinção entre o corpo, enquanto modificável e a alma, enquanto imutável, ela não configura necessariamente uma dualidade, já que a condição de desenvolvimento da alma só se dá a partir do corpo e, ao mesmo tempo, o corpo do homem não pode ser sem alma. Da mesma forma que, a respeito da composição do corpo, o fogo recebe a nutrição da água e a água recebe a capacidade de movimento do fogo, parece-me evidente haver uma sorte de analogia do corpo como fogo e da alma como água, necessários um para o outro.

Explica o tratadista os diferentes modos de combinação dos seres, provenientes das sementes femininas e masculinas. Se houver dominância de uma em relação à outra, dependendo da sua origem (do homem ou da mulher) formar-se-ão tipos de caracteres diferentes. A partir do texto, podemos esquematizar três possibilidades de combinação, subdivididas em pares, propostas no tratado da seguinte maneira:

${ }^{76}$ Da dieta, $1,28$. 
- De ambas as sementes masculinas, provenientes de ambos progenitores, nascerão homens

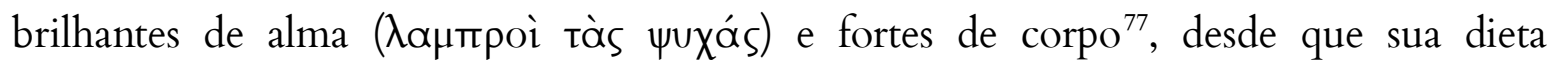
posterior não modifique essa natureza.

- Se a semente masculina for proveniente do homem e a semente feminina, da mulher, e se a semente masculina se impuser, a mais fraca se fundirá com a mais forte e resultará em homens viris, porém menos brilhantes do que os anteriores.

- Se a semente masculina for proveniente da mulher e a feminina do homem, e se predominar o masculino, o procedimento será o mesmo que o anterior e resultará em homens efeminados ou andróginos.

O mesmo parâmetro é utilizado caso haja predominância em todos da semente feminina. Se, como no primeiro caso, ambas forem femininas, o resultado será mulheres muito femininas e belas. Se for como o segundo caso, o resultado será mulheres mais

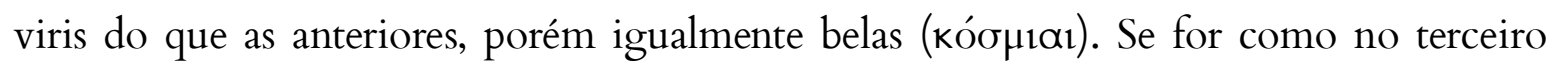
caso, o resultado será mulheres mais valentes do que as anteriores e são chamadas viris

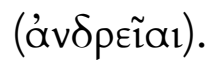

Seguindo essa lógica, o autor continua, dizendo que ambas as almas provenientes das sementes dos progenitores fundem-se uma com a outra:

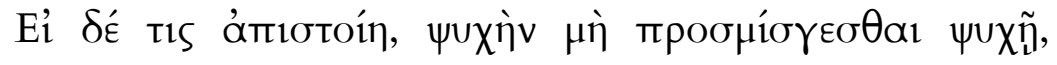

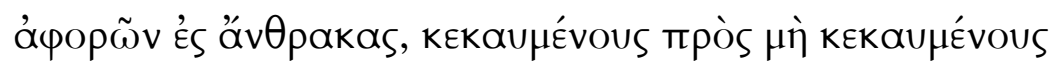

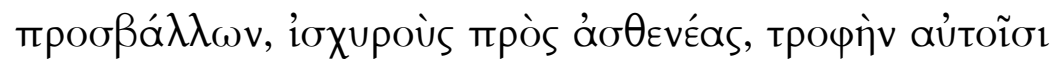

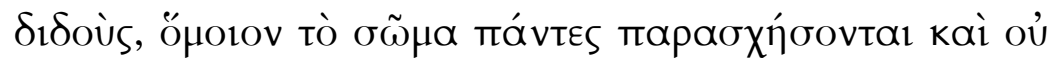

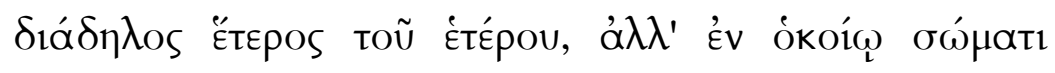

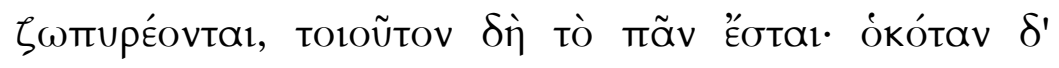

\footnotetext{
77 Note-se a oposição feita entre inteligência e força fisica, bem como a oposição entre virilidade e
} feminilidade. 


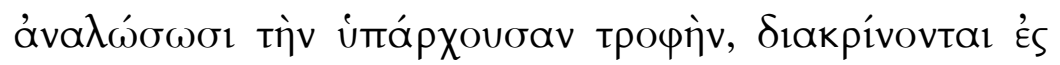

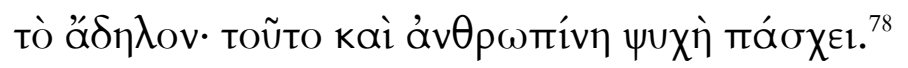

Se alguém não acreditar fundir-se alma com alma, olhando o carvão, que, acrescentando os que ardem aos que não ardem, os fortes aos fracos, dando-lhes nutrição, apresentarão todos o mesmo corpo, não distinguível um do outro, mas queimam juntos em tal corpo, e o todo será, então, assim. Quando, porém, consumirem a nutrição que existe, dissolvem-se no invisível ${ }^{79}$. Isso também sofre alma humana.

Dessa forma, vê-se que a geração da alma e o seu crescimento acontecem no mesmo momento em que a formação da semente. A analogia com o carvão que queima não é por acaso, uma vez que também o processo de crescimento do corpo humano deve-se à ação do fogo. A mudança de um estado a outro é um ponto a ser ressaltado, uma vez que ocorre uma espécie de sublimação da matéria da alma, do mesmo modo que acontece com a do carvão, e uma passagem para o invisível. Não fica claro, entretanto, se essa passagem para o invisível é, de fato, uma sublimação sem resíduo físico, ou se, mesmo invisível, a alma ocupa um lugar específico no corpo, como, de resto, podemos observar em outros tratados hipocráticos que explicitam uma localização física para a alma, seja enquanto $\theta$ unós, ppéves ou voũ ${ }^{80}$.

No capítulo 35 do livro 1, porém, no meio da longa explicação a respeito da inteligência da alma, encontramos oi mópor tĩs $\psi u x \tilde{s}$, indicando a corporeidade da ${ }^{78}$ Da dieta, $1,29$.

${ }^{79}$ p. ext., "indiscernível”.

80 Cf. Cairus, H.F "A Fisiologia do Espírito na Grécia Antiga”. In: Vanderson Esperidião Antonio; Rodrigo Siqueira Batista. (Org.). Neurociências: diálogos e interseções. 1ed. Rio de Janeiro: Ed. Rubio, 2012, v. 1 , p. $463-471$. 
alma, bem como uma estreita relação com os circuitos sanguíneos, ecoando, de certa maneira, as ideias de Alcméon de Crotona no fragmento já citado no capítulo desta Tese a respeito do sono:

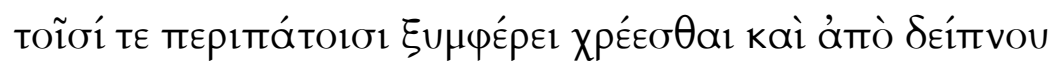

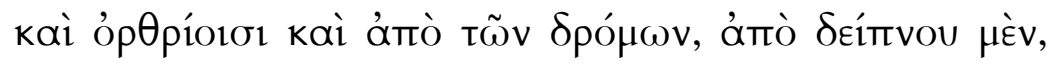

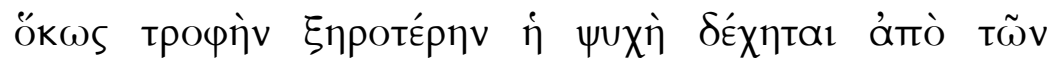

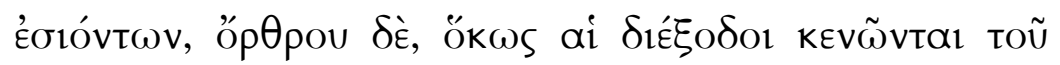

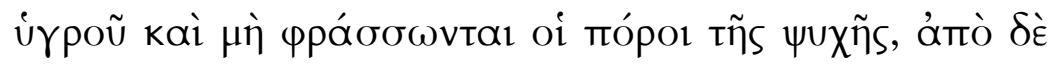

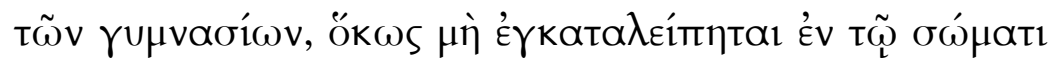

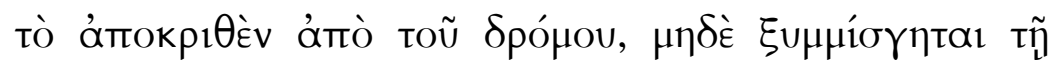

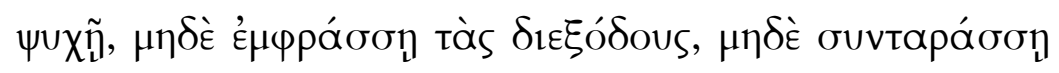
тіेv трофп́v.

Convém fazer uso de caminhadas tanto após a ceia como de manhã e após as corridas; após a ceia, para que a alma receba nutrição mais seca a partir do que entra; matutinas, para que as passagens se esvaziem da umidade e não obstruam os poros da alma; e depois dos exercícios, para que não deixe no corpo o que é secretado a partir da corrida, nem seja misturado pela alma, nem obstrua as passagens, nem perturbe a nutrição.

Até aqui não tinha havido, no tratado, qualquer referência a uma corporeidade tópica da alma. Essa fisiologia anímica é evidenciada não só pela dinâmica da $\psi v \chi \chi$ দ́,

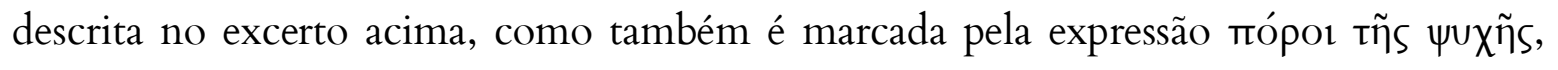


que parecem consistir nas passagens através das quais se dá a relação entre $\psi u \chi \bigvee ́$ e $\sigma \tilde{\omega} \mu \alpha$. Os пópoi não garantem a subsistência da alma, mas sua relação com o corpo, pela via da nutrição e do exercício. A obstrução desses пópoı representa, portanto, um risco para essa relação.

\subsection{A ppóviors da alma}

O contexto dessa passagem no capítulo 35 diz respeito à inteligência da alma. Ali, o autor cria uma pirâmide dos diferentes tipos de alma, com base em sete tipos distintos de combinações entre fogo e água. Poder-se-ia sistematizar as categorias de inteligência da seguinte maneira:

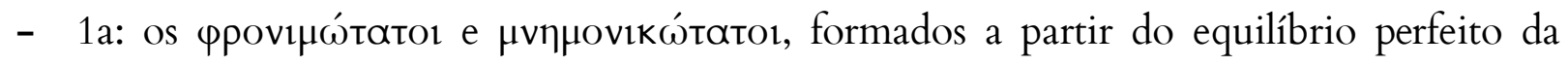

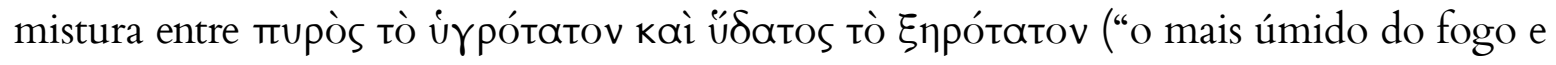
o mais seco da água").

- 2a: Se houver uma leve dominância da água em relação ao fogo, resultarão indivíduos

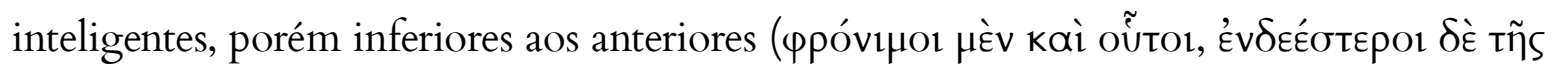

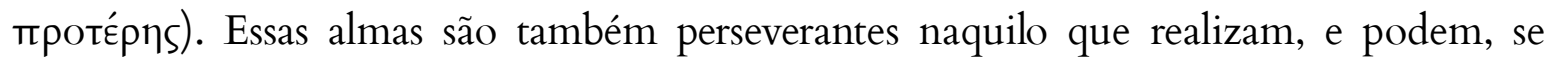
seguirem uma dieta correta, resultar mais inteligentes do que viria a ser sua púors.

- 3a: Se a dominância da água for mais acentuada, a alma será forçosamente mais lenta e

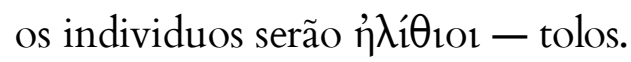

- 4a: Se o fogo for dominado totalmente pela água, o resultado será individuos que alguns

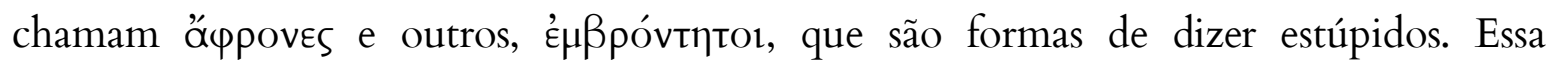
estupidez é uma manifestação de $\mu$ avín, que, segundo o tratado, pode ser desencadeada pela menor inflamação, mas resolvida facilmente por meio de uma dieta que se abstenha de carnes ou alimentos fortes e exercícios violentos. 
- 5a: Se houver leve dominância do fogo em relação à água, a alma será inteligente e perceberá rapidamente o que lhe ocorre. Essa alma é de natureza boa, podendo ser melhor se seguir uma dieta correta, e pior se seguir uma dieta não correta.

- 6a: Se a água for mais dominada pelo fogo, a alma será mais aguda, porém mais instável do que o resto,

- 7a: Se houver dominância mais intensa do fogo sobre a água, a alma será excessivamente

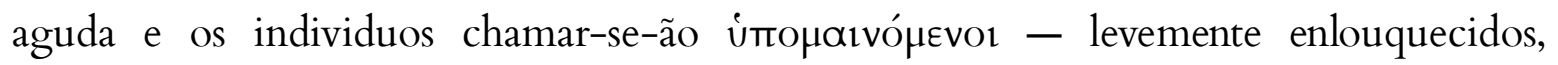
podendo facilmente ser conduzidos à $\mu \propto v i ́ n$.

Encontramos, no capítulo 32, também uma distinção de seis tipos de misturas de fogo e água, de acordo com a sua disposição em relação à saúde e à doença. Embora em ambos os capítulos as categorias lexicais sejam semelhantes (por exemplo, em ambos os capítulos se utiliza os termos "o fogo mais úmido" e "a água mais seca"), as combinações parecem não ser as mesmas, levando a supôr, como sustenta Bartošs ${ }^{81}$, que não se trate de dois tipos de misturas diferentes, mas de uma só, cujos efeitos sejam distintos para a saúde e para a inteligência.

O uso da dieta como elemento modificador dos atributos da alma indica uma possível compreensão de que há, para o tratadista, uma parte da alma que é passível de

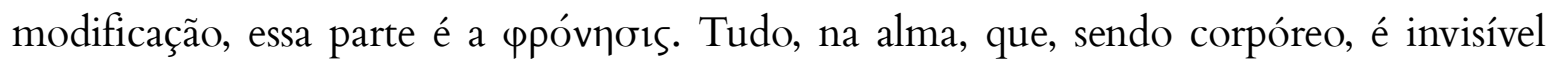
$\left({ }^{\alpha} \delta \eta \eta \lambda \alpha^{82}\right)$ não se modifica.

81 2009, p.10. Hynek Bartoš argumenta contra a hipótese sustentada pela tradição de comentadores do texto de que existe uma dualidade entre corpo e alma. No seu artigo, apresenta evidências que ele julga indicarem um princípio de unidade e os limites dessa leitura dualizante. Essa interpretação também acrescenta dados à relação apontada por quase a maioria dos comentadores entre o texto e as doutrinas órfico-pitagóricas a respeito da alma, indicando que existe de fato, no texto, uma ideia implícita de palingênese e imortalidade da alma. Tendo a concordar com o Bartoš nesse aspecto, pelos indícios apresentados, principalmente pelas ideias contidas no capítulo 3 do Da dieta, em que se argumenta que tudo que existe já existia antes, pela compreensão da alma enquanto oтŕ́p $\mu \alpha$, indicada dos capítulos 6 ao 25 , e pelo capítulo 86 , em que se indica que as sementes provêm dos mortos, apontando, assim, para um ciclo completo. A alusão constante aos deuses ctônicos e aos heróis no texto parece-me também um indício dessa relação, mais do que com os rituais de incubação nos templos dedicados a Asclépio.

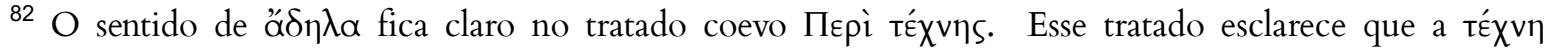

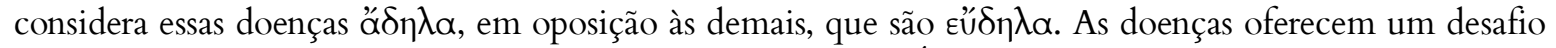

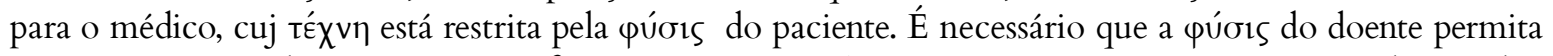
o exame para um diagnóstico mais eficiente. Mas uma púoıs que não é propícia ao exame pode retardar, 
Para Jouanna ${ }^{83}$, as traduções disponíveis da passagem que trata da explicação da terceira categoria de inteligência não apresentam solução satisfatória. Na passagem, lê-se

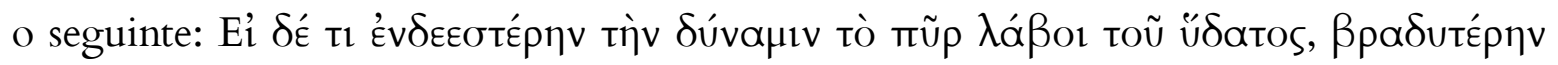

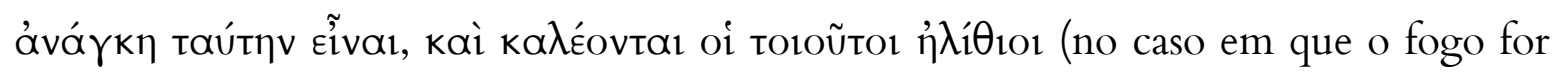
menos poderoso que a água num indivíduo, esse [circuito da alma] é necessariamente mais lento, e esses são chamados tolos). As interpretações de Littré, Jones, Joly e García Gual do termo taútnv refletem-se nas suas respectivas traduções como "alma”. Jouanna, entretanto, compreende, pelo contexto maior e por todas as outras ocorrências, que tal

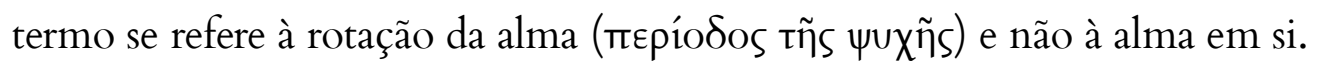

Logo em seguida, o tratadista providencia a explicação, que, segundo Jouanna, não foi bem compreendida por nenhum dos tradutores. A sua solução, por ser radicalmente inovadora em relação à tradição, pareceu-me digna de aqui ser discutida, porquanto resulta de uma discussão textual entre os dois maiores comentadores do texto que refletem dois compromissos, que procurarei também expôr. Assinalo, assim, em negrito os termos problematizados nas traduções, ordenando-os cronologicamente:

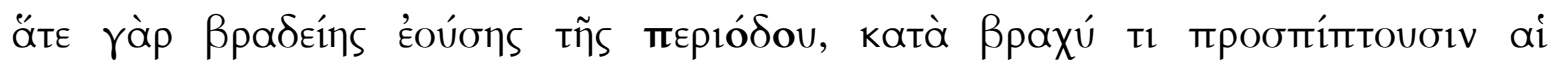

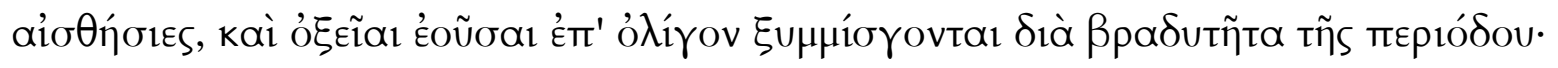

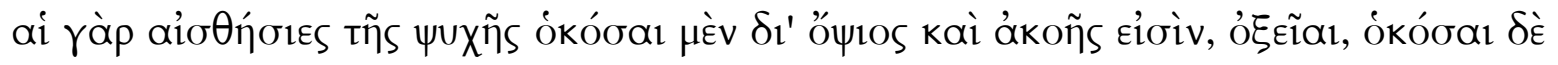

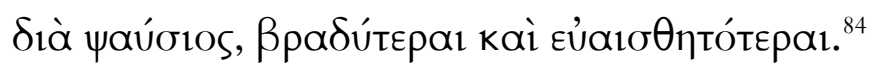

Littré (1887): En effet, la circulation étant lente, les sens ne s'appliquent que brièvement; ils sont rapides, et cette lenteur fait qu'ils ne s'attachent qu'un peu. Les sensations de l'âme qui dépendent de la vue et de l'oüe sont rapides; celles qui dépendent du toucher sont plus lentes et mieux sentantes.

mas não impossibilitar o diagnóstico: "pois o que escapa a visão dos olhos é capturado pela visão da

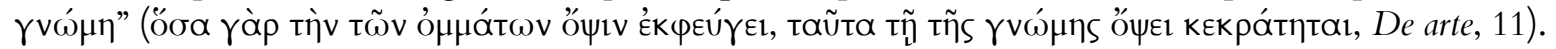
83 2012, p. 202-203.

${ }^{84} \mathrm{Da}$ dieta, 1,35 
Jones (1931): For as the circuit is slow, the senses, being quick, meet their objects spasmodically, and their combination is very partial owing to the slowness of the circuit. For the senses of the soul that act through sight or hearing are quick; while those that act through touch are slower, and produce a deeper impression.

Jouanna - Joly 1 (1967): Étant donné, en effet, que la révolution de l'âme est lente, les parcelles sensibles n'ont qu'un court instant à chaque fois pour s'y précipiter quand elles sont rapides et, par conséquent, ne peuvent s'y mêler qu'en petite quantité à cause de la lenteur de la révolution. C'est que les parcelles sensibles saisies par l'âme, quand elles y pénètrent par le canal de la vue ou de l'ouïe, sont rapides, tandis que quand elles y pénètrent par le canal du toucher, elles sont plus lentes et plus facilement saisies.

Joly 2 (1984) Etant donné, en effet, que la révolution (de l'âme) est lente, les sensations n'ont qu'un court instant à chaque fois pour y arriver quand elles sont rapides et par conséquent, ne peuvent s'y mêler qu'en petite quantité à cause de la lenteur de la révolution. C'est que les sensations saisies par l'âme, quand elles y pénètrent par la vue ou l'ouïe, sont rapides, tandis que quand elles y pénètrent par le toucher, elles sont plus lentes et plus facilement saisies

García Gual (1986): Al ser, por tanto, lento el movimiento circular del alma, en un breve punto la alcanzan las sensaciones, que son rápidas, y en poco se mezclan a causa de la lentitud del movimiento circular. Pues las sensaciones del alma, las que vienen por la vista o el oído son rápidas, y las del tacto más lentas y más fáciles de aprehender.

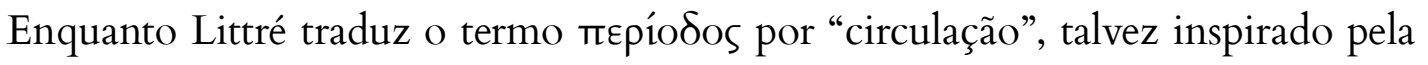
ideia alcmeônica que coloca o sangue como carregador da $\varphi$ póvๆors, Jones traduz como "circuito". Sem embargo, Jouanna, cuja tradução é utilizada por Joly (que o indica em rodapé) na sua primeira edição do tratado pela Editora Les Belles Lettres, traduz tal 
termo como "revolução da alma", uma vez que o termo aparece no Da dieta geralmente para referir-se à rotação no corpo, em comparação a uma rotação astral, e justifica tal

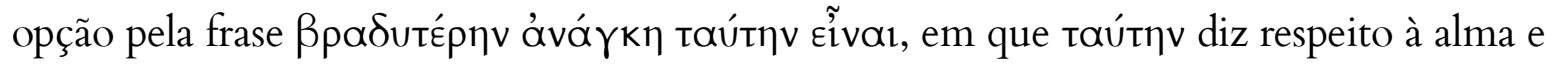

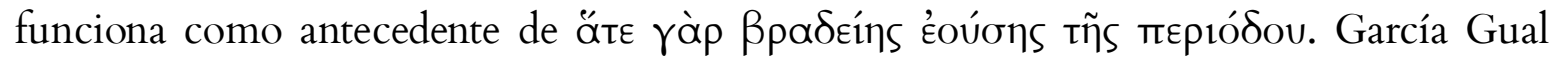
parece seguir aqui a opção de tradução de Jouanna e Joly 1. Joly 2 (na edição de 1984 do $\mathrm{CMG}$ ), por sua vez, prefere manter a dubiedade do complemento do termo $\pi \varepsilon p i ́ o \delta o s$, colocando-o entre parênteses, justificando sua mudança, como mais adiante se poderá constatar.

A discussão se complica quando se trata do termo ai aiơđíores, que todos, exceto Jouanna, traduzem como "sensações". Jouanna opta por traduzir como "parcelas sensíveis", argumentando que o uso no plural de aíoӨnors justifica a compreensão de que o tratadista não se refere à sensação ou à percepção em geral, cuja diferenciação é ali inexistente, mas a um sentido mais específico, compreendido como parcelas sensitivas provenientes do exterior, que penetram o corpo pelas passagens da alma (oi rópor tĩ

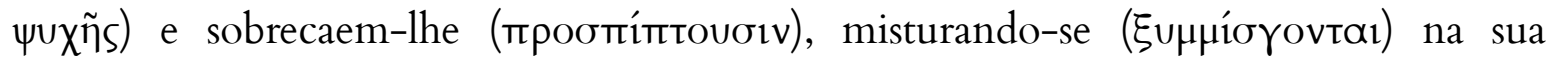

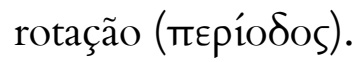

In the singular, aio $\theta$ nors means the faculty of perception in general or sensation. There is no difference for our author between sensation and perception. In the plural, which is what concern us here, aio $\theta \dot{j} \sigma i \varepsilon s$ normally means either sensations or sensory organs. We can immediately disregard a translation of aio $\theta \dot{\sigma} \sigma i \varepsilon s$ with 'sensory organs',

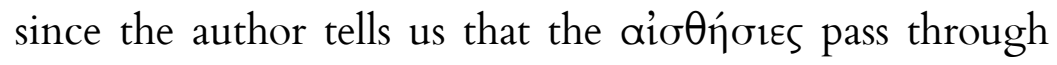
the channel of sight, hearing, touching, i.e. the sense channel. The solution that remains is to translate it as 'sensations'. Unfortunately this hypothesis leads us to an array of difficulties and absurdities, if, at least, we 
understand 'sensations' in the modern sense. Where do the sensations of the soul hurry to? Towards the object, as translators think. But now, with what do they mix? Above all, how can the sensations of the soul be quick when the soul's rotation is slow? If they were quick, they would hurry to their objects and the soul would be more intelligent, but the author wishes to show us the opposite. ${ }^{85}$

$\mathrm{O}$ argumento de Jouanna para traduzir aiợ́øıєs por "partículas sensitivas" pauta-se na ocorrência de estruturas semelhantes em dois textos diferentes, especialmente nos fragmentos do pitagórico Arquitas de Tarento ${ }^{86}$ e no Teeteto de Platão ${ }^{87}$. Jouanna aponta que, nesses textos, tais partículas são designadas pelos particípios neutros plurais,

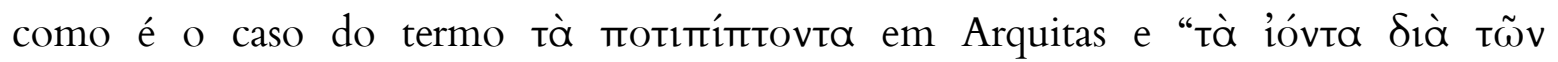

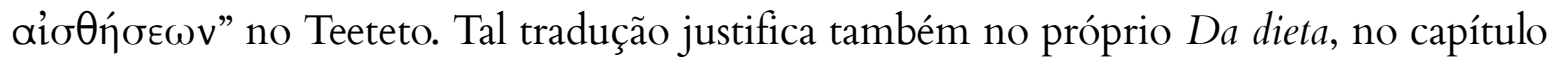
35, em que o neutro plural também é empregado, a respeito da alma que rapidamente

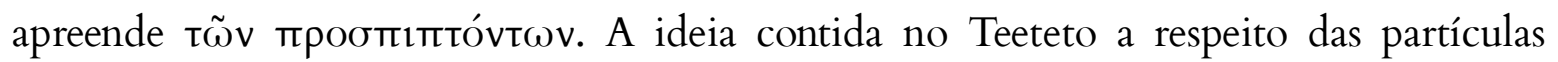
sensoriais da alma, entende a alma como um pedaço de cera que é estampado pelo que entra pelos canais sensoriais.

Essa concepção de alma estática, entretanto, não se reflete no Da dieta, em que há a indicação clara de movimento circular da alma. Na visão de Jouanna, escorado nas leituras de Arquitas e de Platão, essas partículas da alma referidas no Da dieta, pelo seu movimento circular, se aproximam das partículas sensoriais, que ficam alojadas nas portas

\footnotetext{
${ }^{85} 2012$, p. 206.

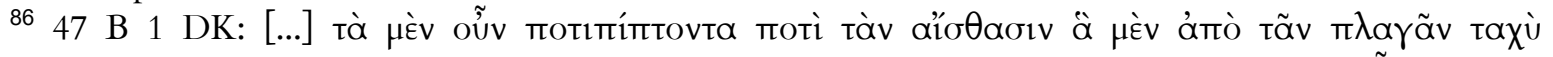

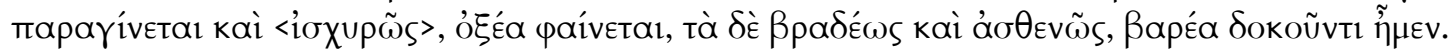

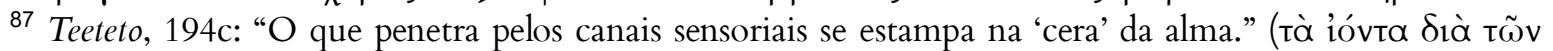

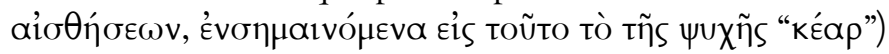


da alma, para apreendê-las. Dependendo se o movimento da rotação é mais rápido ou mais lento, isso terá um reflexo na inteligência do indivíduo.

Jouanna ainda elucida uma questão que parece ficar obscura, pois o tratadista

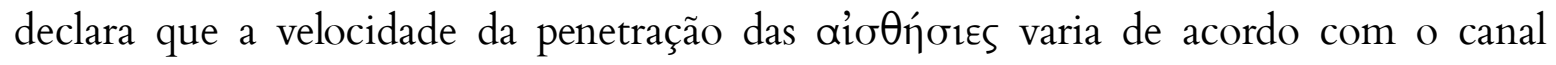
sensorial: enquanto os canais da vista e do ouvido são mais rápidos, o canal do tato é mais lento. Isso levaria à suposição de que as partículas que chegam pelos canais mais rápidos penetrem a alma mais rapidamente e se misturem em grandes quantidades. Entretanto, o que acontece é o oposto: segundo o texto do Da dieta, as partículas rápidas

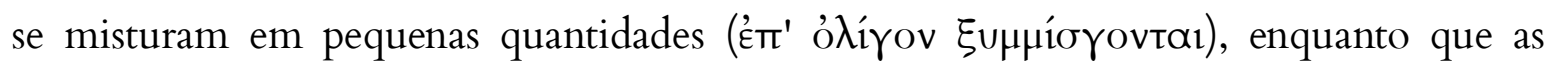

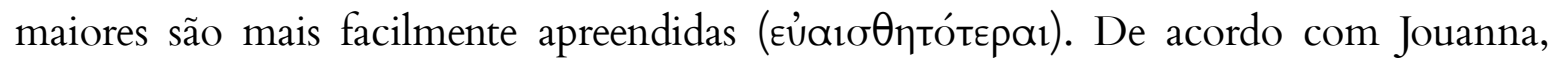
"we can simply suppose that the particles that arrive rapidly leave again equally rapidly, and only remain for a short instance each time (katà $\beta \rho \alpha \chi u ́ v$ rl) in the gates of the soul" $\$ 88$.

$\mathrm{Na}$ sua primeira edição do texto, Joly utiliza a tradução de Jouanna, porquanto “M. Jouanna [...] est le premier à elucider la theorie ici exposée" ${ }^{89}$. Entretanto, na sua edição posterior de 1984, no CMG, esclarece sua opção por "sensações" em vez de "partículas sensitivas", uma vez que parte da ideia de que a sensação seria um misto de um estímulo proveniente do exterior com uma impressão sentida pela alma ${ }^{90}$ :

Dans ma première édition, j'avais accueilli telle quelle la traduction que J. Jouanna proposait (La théorie de l'intelligence, p. XVIsq.) en même temps que sa brillante interprétation. On la retrouvera ici, mais retouchée sur un

\footnotetext{
${ }^{88}$ Jouanna, 2012, p. 208.

${ }^{89}$ Joly, 1967, p. 31, nota 1.

90 Tal concepção parece-me ter compromisso com uma ideia moderna de sensação, como é de praxe nos escritos do autor, que busca observar no texto antigo conceitos da medicina moderna, em uma postura um tanto positivista, que, de resto se reflete nos seus escritos, como é o caso do livro Le niveau de la science hippocratique (1966).
} 
point. Je n'admets plus aujourd'hui la traduction de

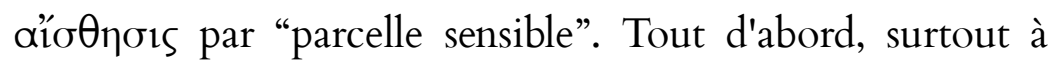
propos de textes aussi difficiles, je pense que la traduction doit mieux refléter l'ambiguiité éventuelle du grec. Ensuite, la raison invoquée par J. Jouanna me paraît contestable: "La comparaison entre les deux expressions où les termes sont

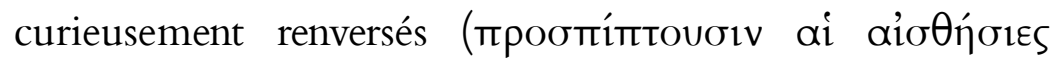

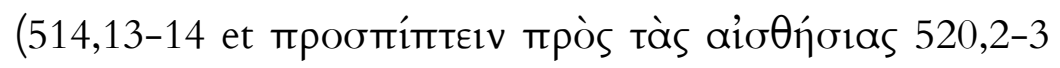

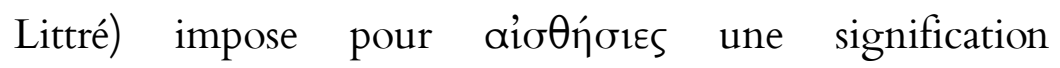
particulière (mais pas unique): il s'agit des parcelles sensibles, émises par les objets, qui se précipitent vers l'âme et vers lesquelles l'âme se précipite, selon un double mouvement opposé et complémentaire" (p. XVI). La sensation étant un mixte, une conjonction d'un stimulus extérieur avec une impression ressentie par l'âme, il est aussi naturel de dire que la sensation va vers l'âme que l'inverse, sans que cela impose la notion de parcelles sensibles. Il n'est question nulle part ailleurs dans le Régime de parcelles émises par les objets, ce qui serait assez proche de la représentation démocritéenne. J. Jouanna croit retrouver ce sens rare de "parcelles sensibles" dans le Timée: p. 44 A, et il est vrai que l'expression qu'on trouve là est très proche de celles $d u$

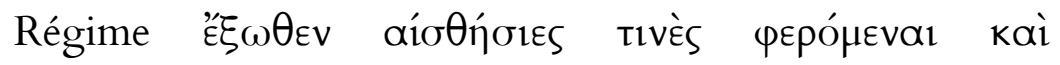

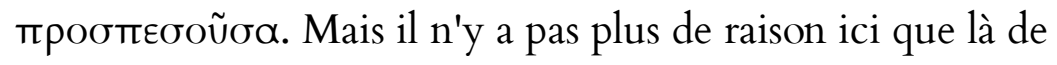
ne pas traduire par "sensations". Pour Platon, la vue et l'ouïe résultent essentiellement de mouvements transmis (p. 45D; $67 \mathrm{~B}) .{ }^{91}$

$\overline{{ }^{91} \text { Joly \& Byl, 1984, p. 259-260 }}$ 
$\mathrm{Na}$ sua resposta, Jouanna argumenta que, embora o termo não deixe espaço para a ambiguidade sugerida no texto, sustenta que o uso moderno de "sensação" proposto

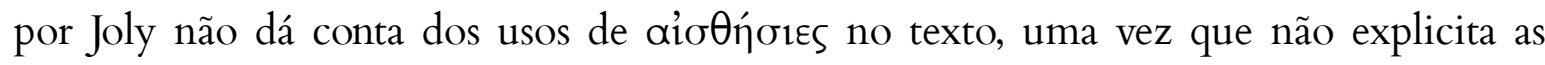
manifestações concretas indicadas pelo neutro plural:

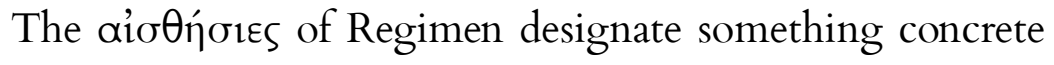
coming from the object and rushing in from outside in order to be perceived by the soul. We may add that this

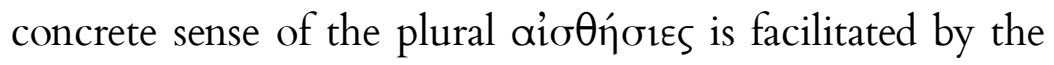
well-known use, in Greek, of abstract terms in the plural referring to concrete manifestations.

A discussão acerca do sentido de aiơfíores segue um roteiro análogo ao sugerido por Jouanna em relação a outro conceito muito caro à compreensão do tratado

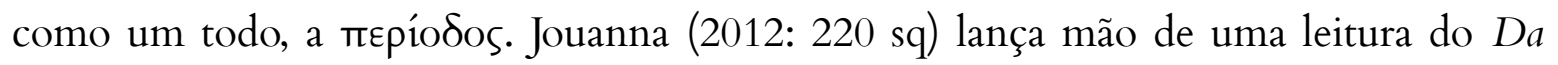
dieta espelhada no Timeu de Platão, com o fim de respaldar a sua ideia de que o termo

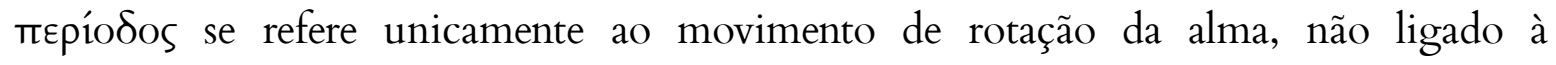
circulação, como implicam Littré e Jones nas suas respectivas traduções.

Nessa comparação com o Timeu, é possível apontar para uma série de coincidências, principalmente o uso do mesmo vocábulo para designar o movimento da alma no corpo e sua relação macrocósmica com as revoluções dos astros, de modo similar ao Da dieta. sendo, entretanto, o sistema astronômico platônico um tanto mais complexo do que o do nosso tratadista. Enquanto no Da dieta são explicitadas três

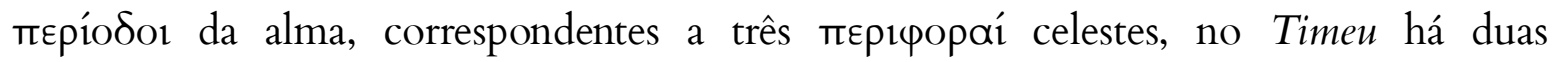

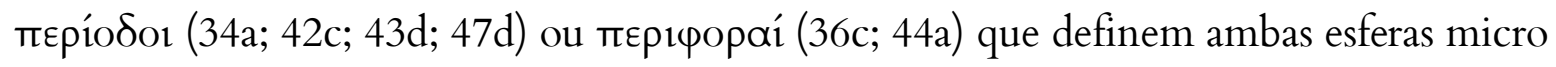
e macrocósmicas. Enquanto Jouanna aponta a uma alternância vocabular que ele 
considera indiscriscriminada em ambos os textos, eu discordo que no Da dieta seja assim: considerando que sua análise se limita ao conceito de ppóvๆors exposto no capítulo 35, o helenista francês não parece observar os indícios dos capítulos 86 em adiante, que compõem o Livro IV, em que parece haver uma clara distinção entre as rotações celestes

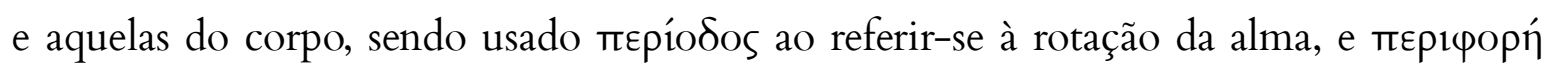
para a dos astros.

Há, em ambos os textos, a indicação de que a inteligência depende do movimento de rotação da alma: para o tratadista, a inteligência é perfeita quando há um movimento da alma perfeito. No Timeu é semelhante. Quando as rotações do Mesmo e do Outro têm o movimento e trajetória ideiais, o conhecimento, seja ele racional ou conceitual, é perfeito. Em ambos, se houver alteração nas rotações, isso pode derivar em perturbações mentais, podendo chegar à loucura.

Essa patologia presente no Timeu também aproxima os dois textos, e pode ser vista, à guisa de exemplo, em 43b-44c, em que Platão descreve a entrada das rotações da alma imortal no corpo. De acordo com o texto, uma vez atrelada ao corpo, a alma sofre sérios problemas, tendo suas rotações perturbadas, e, estando a do Outro deslocada, a do Mesmo diminui o movimento e para, causando que a alma se torne óvous. Essa explicação fisiológica continua, explicando que o excesso de nutrição perturba a rotação da alma, de uma forma que lembra as explicações hipocráticas a respeito da pletora provocada pelo alimento:

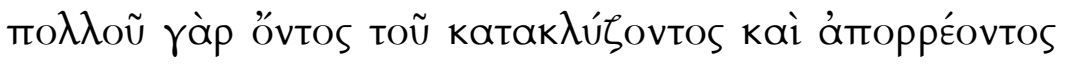

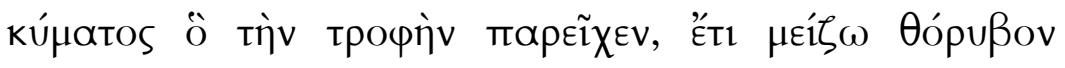

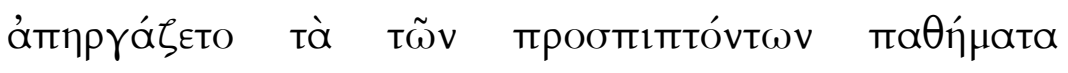

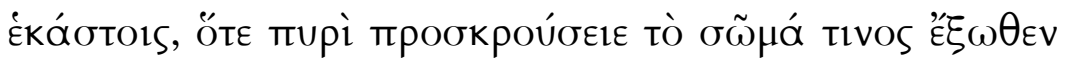

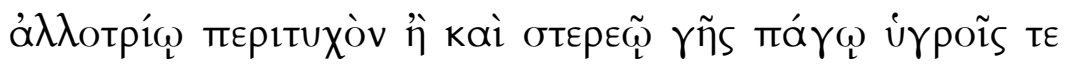

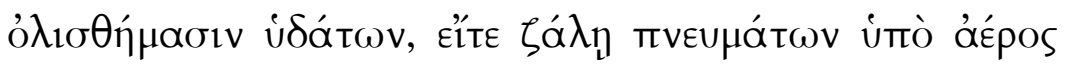

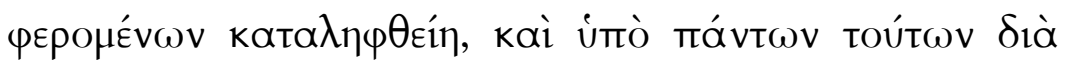




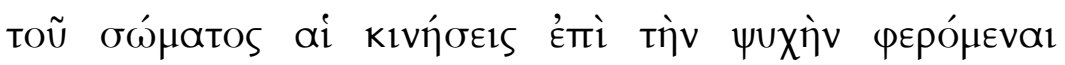

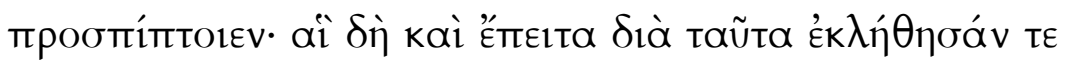

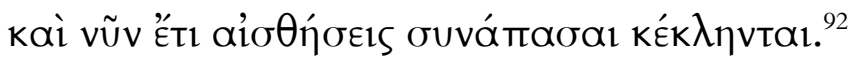

É que, por ser abundante a torrente de fluxo e refluxo que transportava o alimento, as impressões que com eles chocavam causavam um tumulto ainda maior, sempre que o corpo de algum colidia com um fogo externo que por acaso encontrasse no exterior, ou com a dureza e firmeza da terra, ou com a umidade deslizante da água, ou apanhado pela tempestade dos ventos transportados pelo ar; ou seja, quando, causados por todas essas entidades, os movimentos, imprimidos ao corpo, recaíam sobre a alma. Por causa disso, esses movimentos foram chamados sensações, e ainda agora, no seu conjunto, são assim chamados. ${ }^{93}$

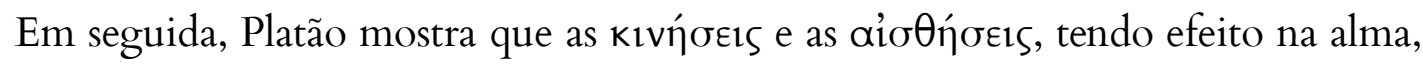
junto com a torrente de fluxo de alimento, são as responsáveis pela perturbação das rotações da alma (43d), alterando a rotação do Mesmo e fazendo com que, ao bloqueá-la e, por correrem em sentido oposto, perturbem completamente a rotação do Outro, o que

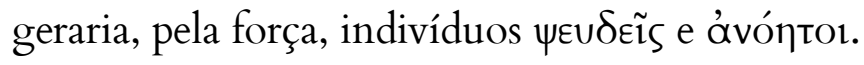

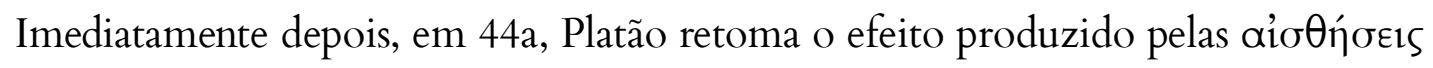
nas rotações da alma:

\footnotetext{
${ }^{92}$ Timeu, 43 b-c

${ }^{93}$ Trad. Rodolfo Lopes, 2011.
} 


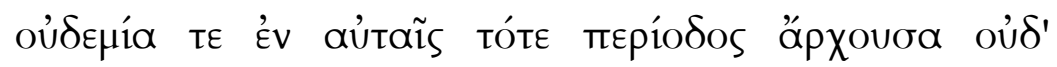

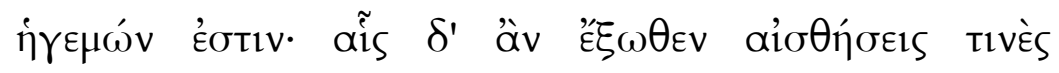
фєрó

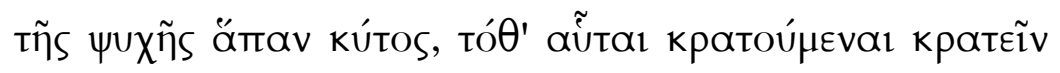

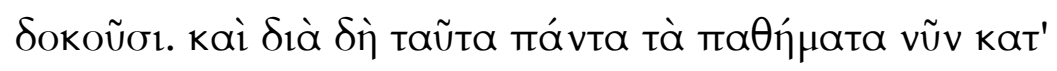

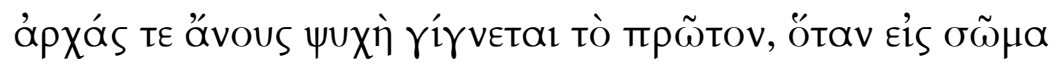

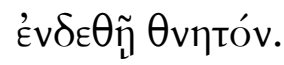

[...] visto que nenhuma das órbitas que há nelas governa ou orienta. Porém, quando nelas recaem certas sensações vindas do exterior, arrastando consigo todo o invólucro da alma, as órbitas aparentam estar no comando, quando são elas as comandadas. É por causa de todas estas impressões que, agora e tal como na sua origem, a alma é primeiro gerada sem intelecto cada vez que é aprisionada num corpo mortal. $^{94}$

A relação com o capítulo 35 do Da dieta é possível de ser constatada pelo uso dos

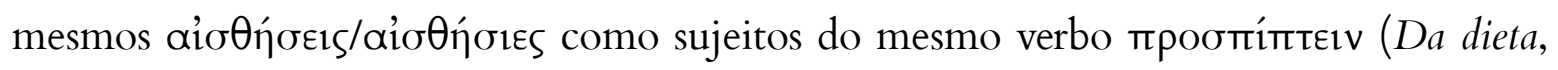

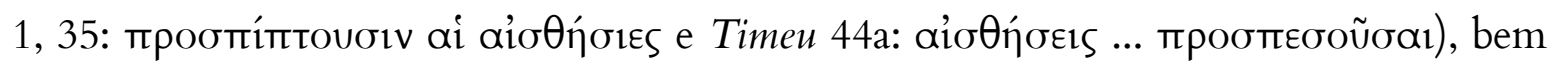
como o efeito provocado pelo movimento dessas partículas provenientes do exterior em relação ao movimento de rotação da alma. Segundo Jouanna, não existe evidência de texto pré platônico que associe o conceito de sensação/percepção/inteligência ao movimento de rotação da alma. Na opinião dele,

${ }^{94}$ idem. 
This dynamic representation of aio $\theta$ íoels finds etymological support in the text of the Timaeus, if we use the phrase where Plato justifes the designation of

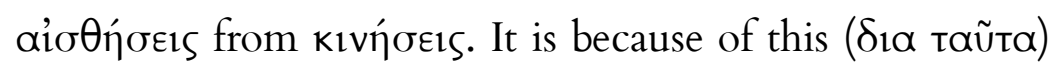
that they are called aio $\theta \dot{\eta} \sigma \varepsilon 1 \varsigma$, i.e. because they were moving. Thus, Plato justifies the name aio $\theta \dot{\eta} \sigma \in 1 \zeta$ with an etymological explanation which connects the noun with a term designating movement. ${ }^{95}$

Essas relações, indica Jouanna, além de apontarem a uma convergência para uma fonte comum, indicadas pelas semelhanças entre ambos os textos e as estimativas de datação, não excluem a probabilidade de Platão de fato ter lido o tratado Da dieta e ter tomado "emprestados" tais conceitos a respeito da discussão da inteligência em relação ao movimento de rotação da alma. Tal hipótese preencheria uma lacuna a respeito de uma suposta origem dessa ideia, que geralmente passa diretamente por Empédocles ${ }^{96}$.

Apesar das semelhanças, é preciso apontar uma divergência, que, de acordo com Jouanna, marca um estágio importante na história do pensamento: diferente do Da dieta, em que as rotações da alma se situam em torno à cavidade central no corpo, no Timeu elas se localizam no cérebro. De qualquer maneira, a conexão entre ambos os textos parece ter sido negligenciada pela tradição. Seja como for, a leitura a partir de um suposto eco platônico, reflete-se na compreensão do texto hipocrático, de certa forma, revolucionando também a ideia de uma aíoӨnors hipocrática mais comprometida com um sentir e perceber da vivência antiga do que com uma concepção moderna, como quer apontar Joly.

\footnotetext{
${ }^{95}$ Jouanna, 2012, p. 225.

${ }^{96}$ como atesta o artigo de J.P. Hershbell, "Empedoclean In־fluences on the Timaeus," Phoenix 28, 1974, pp. 145-166.
} 
A questão do movimento de rotação da alma como um reflexo fisiológico ligado à esfera macrocósmica só é possível a partir de um conceito fundamental explicitado no texto $D a$ dieta, mas que também é o elemento responsável por tal relação no texto

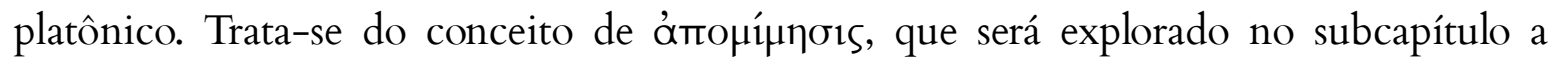
seguir.

\section{3. 'Атонінпण1S}

Walter Burkert, no seu Lore and Science in Early Pythagoreanism, de 1977, utiliza o exemplo da relação micro-macrocósmica da medicina hipocrática para a sua

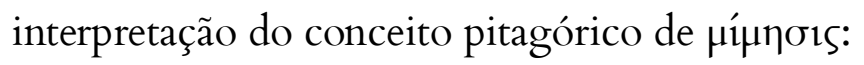

In the Hippocratic writings the relation of microcosm and macrocosm becomes a matter of 'imitation', but [...] this imitation may be turned either way. One may just as well say that the human body 'imitates' the cosmos as that the parts of the cosmos 'imitate' human organs. In the same way, either the arts imitate nature or nature imitates the arts. Imitation is a two-sided correspondence, which makes it possible to interpret separate things following the same pattern, but without implying differences of rank or a relationship of ontological priority. ${ }^{97}$

\footnotetext{
$\overline{97}$ Burkert, 1972, pp. 44-45.
} 
Tal conceito, de acordo com o autor alemão, deve, no entanto, ser desprovido do seu estatuto ontológico, característico da conceituação platônica, que resulta na sua tão conhecida Teoria das ideias, mas que também está presente, mesmo que implicitamente, em toda a sua produção. Face às ideias propostas por Platão a esse respeito, Aristóteles, na Metafísica, afirma tratar-se de uma diferença terminológica, mais do que conceitual:

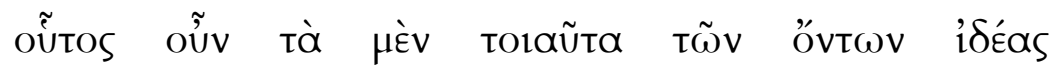

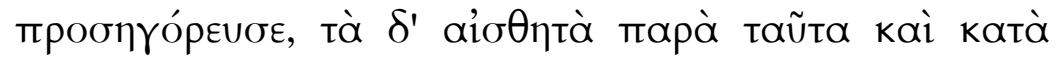

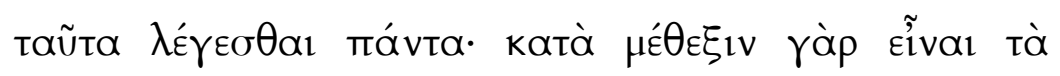

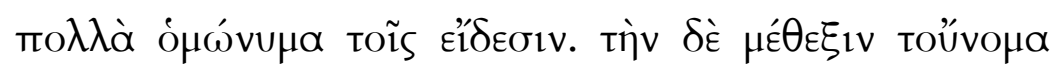

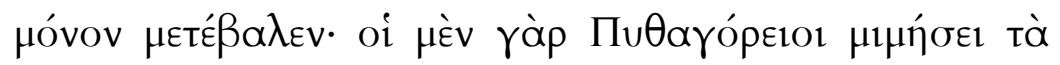

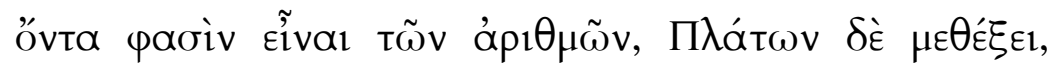

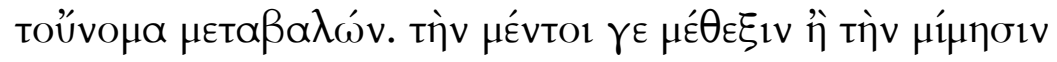

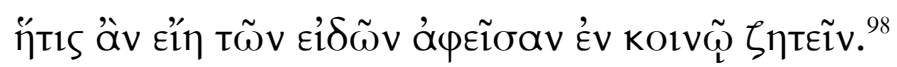

Então, ele chamou essas outras realidades Ideias, afirmando que os sensíveis existem ao lado delas e delas recebem seus nomes. Com efeito, a pluralidade das coisas sensíveis que têm o mesmo nome das Formas existe por "participação" $(\mu \in \hat{\varepsilon} \theta \varepsilon \xi \xi \varsigma)$ nas Formas. No que se refere à "participação", a única inovação de Platão foi o nome. De fato, os pitagóricos dizem que os seres subsistem por "imitação"

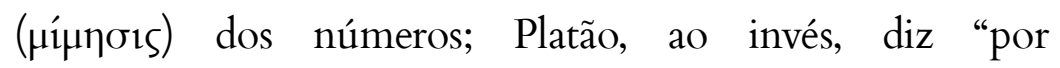
participação", mudando apenas o nome. De todo modo, tanto uns como o outro descuidaram igualmente de indicar o que significa "participação" e "imitação" das Formas.

\footnotetext{
${ }^{98}$ Metafísica, 987 b7-14. Trad. Giovanni Reale.
} 
Ainda Burkert, que comenta tal passagem da Metafísica, indica que Aristóteles

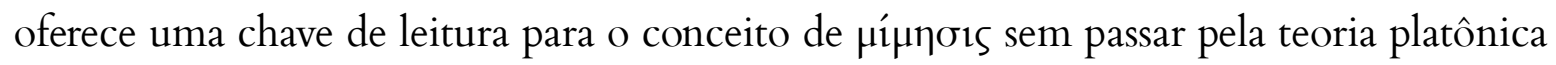
das ideias, que, como define Bartoš ${ }^{99}$, viria a ser "a relação de prioridade ontológica, em que uma coisa é imitada como um padrão ou paradigma e a outra a imita como cópia (ou duplicado) derivada dela”:

Evidently Aristotle knew the Pythagoreans had used the

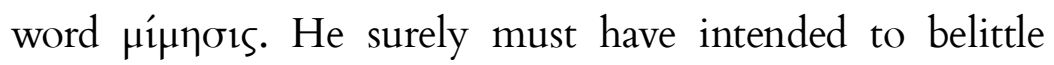
Plato's originality in the doctrines which Aristotle himself

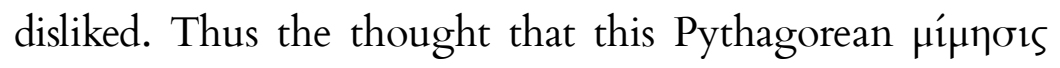
was the same as $\mu \dot{\varepsilon}^{\prime} \theta_{\varepsilon \xi_{1 \zeta}}$, and therefore implied a theory of ideas, will be seen to be interpretation. Aristotle does give some clues as to how imitation can be understood without a theory of ideas. The word 'immanence' is no help, but he does say that the Pythagoreans supposed they saw

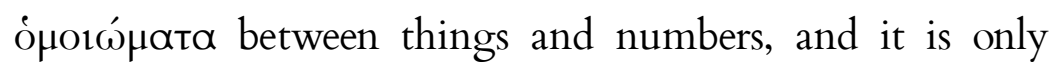
natural to express such similarity or correspondence by the

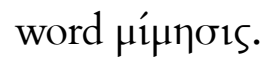

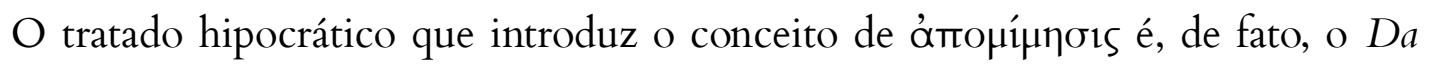
dieta. Há, na Coleção, apenas um outro tratado, o De hebdomadibus, muito fragmentário

\footnotetext{
${ }^{99}$ Bartoš, 2014, p.543
} 
e de datação contestada ${ }^{100}$, que, apesar de a autoria certamente não ser a mesma, apresenta ideias semelhantes às do nosso texto, em relação a esse ponto específico.

O conceito de ámouíñoıs é apresentado no capítulo 10 do livro I do Da dieta, e se insere depois das explicações das partes e do funcionamento do corpo (destacando-se a formação da cavidade central do corpo - a koi $\lambda$ ín), e das explicações de teor embriológico que dizem respeito à geração das partes e da alma do corpo. Ali, o tratadista expõe que o princípio de formação do corpo se dá a partir do fogo, como uma

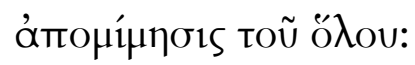

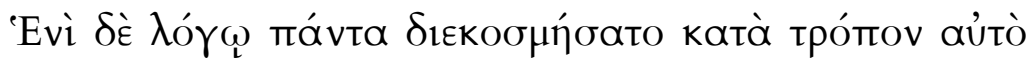

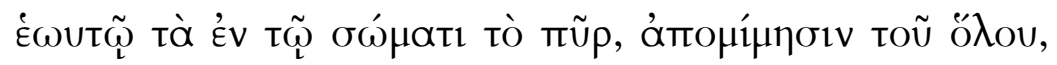

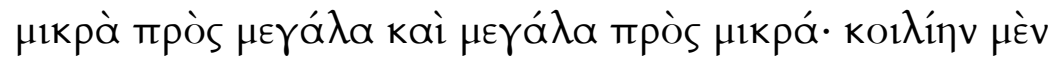

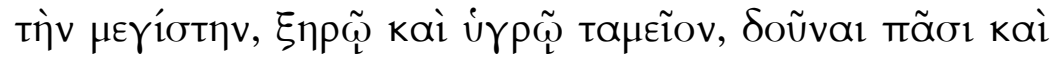

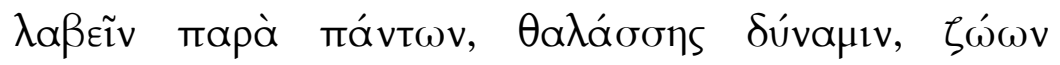

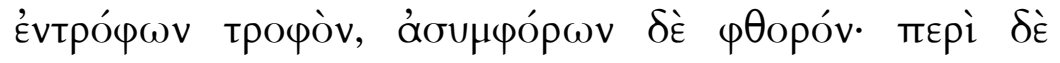

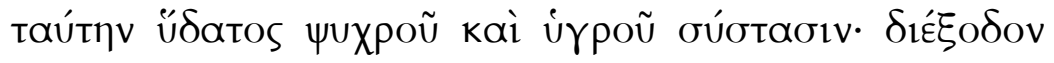

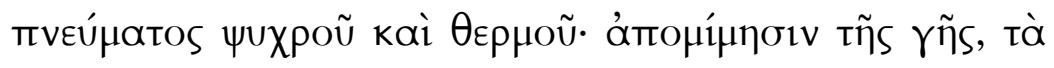

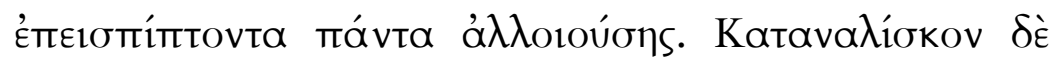

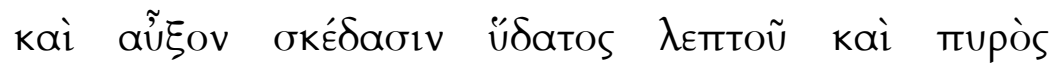

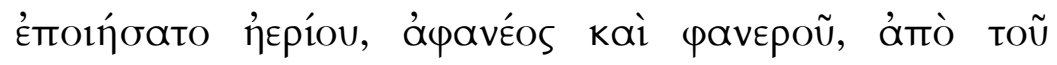

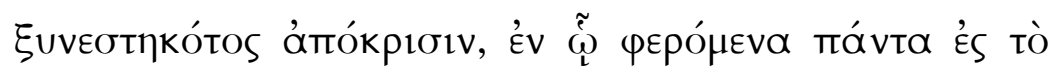

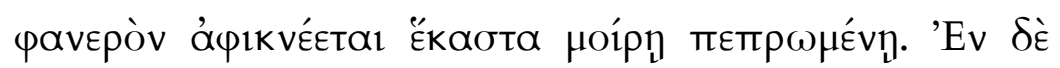

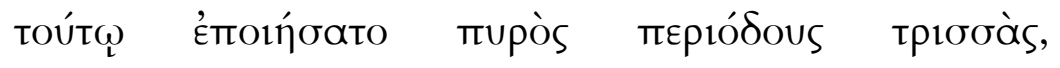

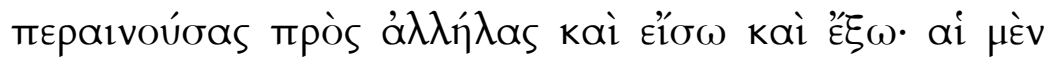

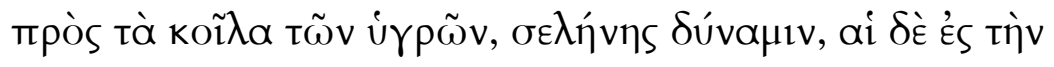

100 Cf. M.L. West “The Cosmology of 'Hippocrates', De Hebdomadibus”. The Classical Quarterly, New Series, Vol. 21, No. 2 (Nov., 1971), pp. 365-388. West aponta uma datação próxima à do Da dieta, no final do século V, enquanto que J. Mansfeld (apud Bartoš, p.544, nota 8) o situa no século I da nossa Era. 


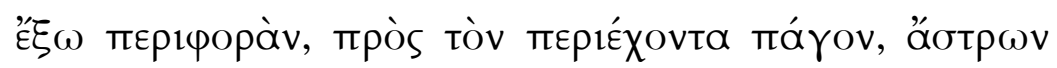

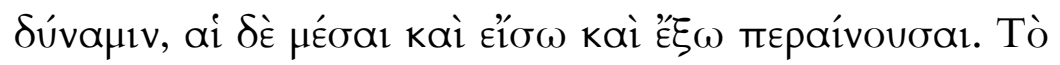

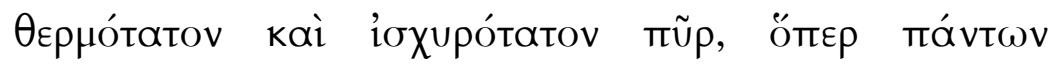

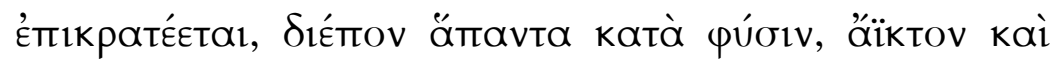

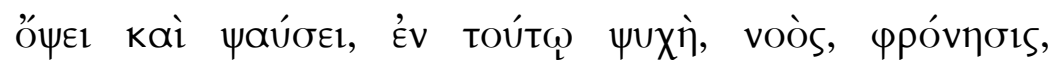

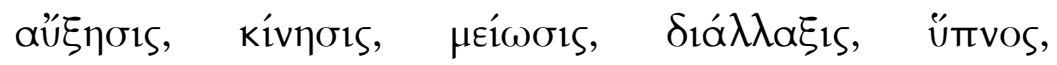

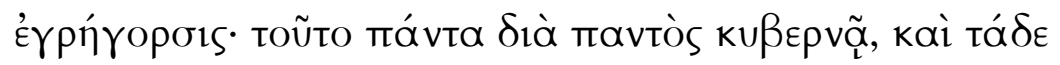

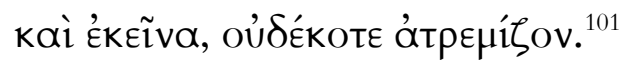

Em uma palavra, o fogo deu ordem, da maneira que lhe é própria, àquilo que está no interior do corpo, como uma

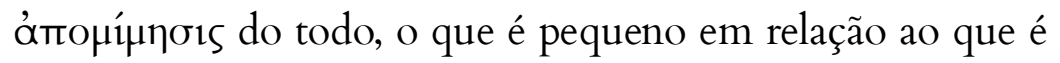
grande e o que é grande em relação ao que é pequeno; sendo o ventre o maior [dos órgãos], receptáculo do seco e do úmido, fornece a todos e recebe de todos, [tem] a propriedade do mar, alimentador dos animais que servem de alimento e destruidor do que não é assimilado. Em torno dele, há uma condensação da água fria e úmida; passagem

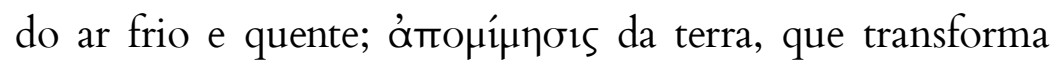
todas as coisas que caem [sobre ela]. Consumindo umas e aumentando outras, produziu uma difusão de água leve e do fogo aéreo, do invisível e do visível, uma secreção do que foi criado, em que tudo o que é levado chega ao visível, cada um com a parte destinada. Nele, o fogo fez três circuitos, ligados uns aos outros tanto por dentro quanto por fora. O que está próximo à cavidade do úmido tem a propriedade da lua; outro, na órbita externa, próximo

${ }^{101}$ Da dieta, 1, 10 
ao que envolve a superfície tem a propriedade dos astros, e o do meio se conecta tanto com o interior quanto com o exterior. O mais quente e forte fogo, que tudo domina, organiza tudo de acordo com a púors, inalcançável tanto à vista quanto ao tato, e nele está a alma, a inteligência, o pensamento, o crescimento, o movimento, a diminuição, a separação, o sono e a vigília. Ele conduz tudo a partir de tudo, tanto isso quanto aquilo, nunca permanecendo parado.

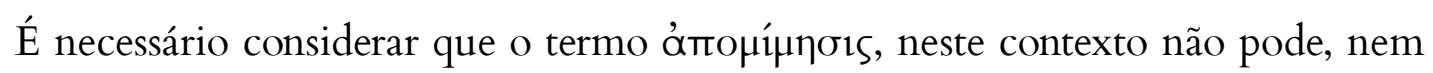
deve ser traduzido por “imitação" ou “cópia”. Como já foi explicitado nos parágrafos anteriores, essa ideia parece-me implicar uma visão platonizante do texto; principalmente, porque pressupõe a ideia de um modelo a ser copiado, o que exclui todo o princípio de reciprocidade que o conceito implica no tratado, em que existe uma relação mútua do macro e do microcosmo, entre o corpo e o todo, e vice-versa, assim como entre o corpo e suas partes, participando um da natureza do outro. "Analogia", por

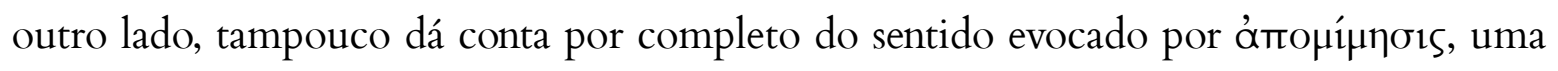
vez que tal processo depende exclusivamente da cognição, funcionando como um tipo de sistema de inteligibilidade da representação ou de sua projeção. A analogia consiste,

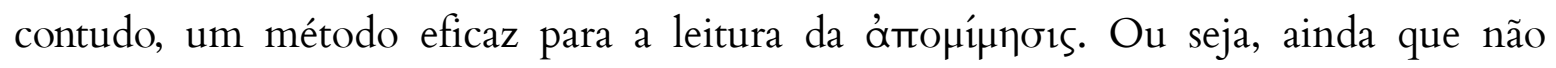
corresponda à operação apomimética, ela é eficaz como ferramenta para a leitura dessa operação, e o tratadista lança mão desse instrumento.

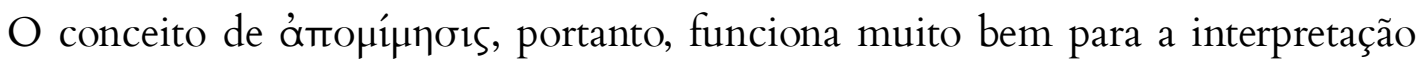
dos sonhos, porquanto essa, sim, depende da cognição, como se pode ler no livro IV, em que a compreensão das imagens se apoia em um saber específico, em uma бopín, no dizer do texto. Lê-se no final do cap. 86: "Assim, quem sabe discerni-las (todas as 
funções do corpo ou da alma, todas essas coisas a alma realiza no sono) corretamente, sabe grande parte da бớín”.

Assim, quando o nosso tratadista se refere à koı $\lambda i ́ n$ - a cavidade central do corpo, em torno da qual se organizam os circuitos da alma e em cujo centro se encontra o fogo

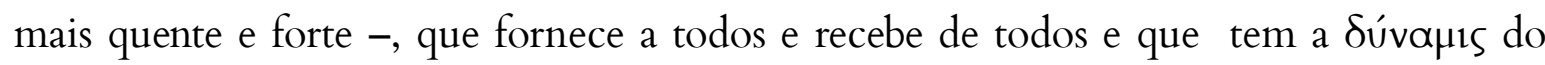
mar "alimentador dos animais que servem de alimento e destruidor do que não é assimilado", é possível pensar que ele se refere à sua capacidade de receber a nutrição e de digerir todo tipo de alimentos.

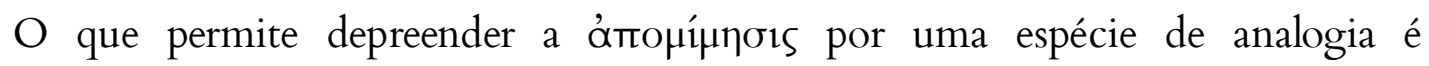

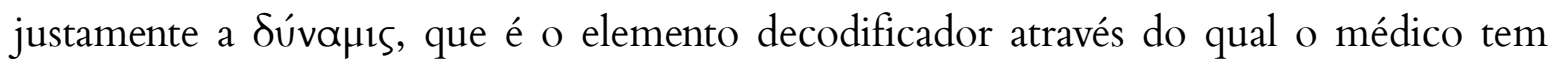
acesso à púøıs. Na passagem acima referida, quando a respeito dos circuitos localizados em torno à koı $\lambda i ́ n$, lê-se: "O que está próximo à cavidade do úmido tem a propriedade da lua; outro, na órbita externa, próximo ao que envolve a superfície tem a propriedade dos astros, e o do meio se conecta tanto com o interior quanto com o exterior". Tal trecho tem ressonância no capítulo 89 , em que o autor parece retomar tais ideias para relembrar que a noção de que os três circuitos concêntricos se estruturam tal qual as três esferas celestes:

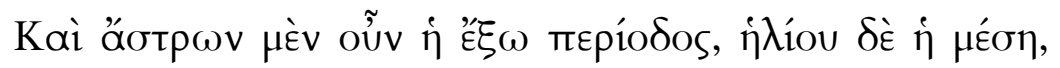

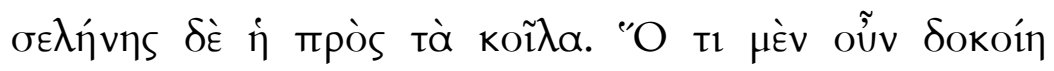

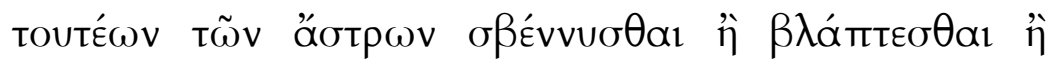

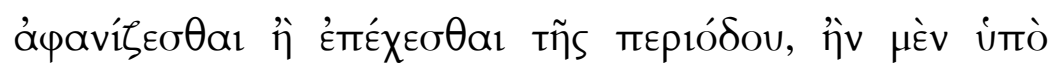

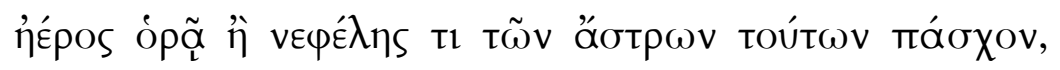

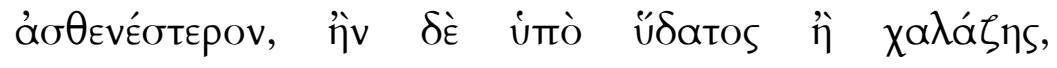

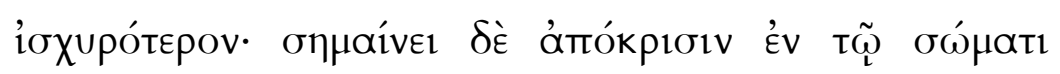




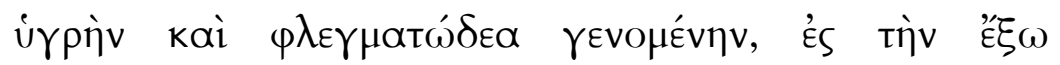

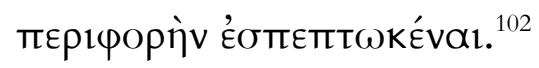

O circuito externo é próprio dos astros, o mediano é próprio do sol e o mais próximo à cavidade é próprio da lua. Então, se algum dos astros parecer prejudicado, desaparecer ou for impedido no seu circuito, seja pelo ar ou por uma nuvem, é mais fraco. Se for por água ou por granizo, é mais forte. Significa que há uma secreção no corpo úmida e fleumática no corpo que sobrecaiu sobre o circuito externo

As imagens da passagem mostram claramente a indicação de um estado de anormalidade, frente a um estado de normalidade que determina saúde, como é o caso de ver em sonho os astros puros e brilhantes com as suas órbitas desimpedidas (cap. 89), ou mesmo em relação a outras imagens que também se inserem nesse padrão de normalidade associado à saúde, como por exemplo, ver mortos trajando vestes brancas (cap. 92), frente a mortos trajando vestes negras. A partir dali, se estabelece um padrão de correspondências que servirão de base para o saber próprio da interpretação dos sonhos como prodiagnose. A respeito disso, Bartoš observa que a correspondência entre ambas as estruturas, microcósmicas e macrocósmicas, depende de certos princípios de caráter universal que se apresentam em todos os níveis do real:

In order to interpret dream visions in relation to the bodily conditions, all we need to know is that the microcosmic and macrocosmic structures correspond to each other

${ }^{102}$ Da dieta, IV, 89 
simply because they share certain universal principles immanently present at all levels of reality. The dreaming soul apparently follows these universal principles and visualizes the bodily states in the form of dream visions. We can remember our own visions, but, unless we are trained in dream interpretation, we cannot understand that they actually reflect our bodily state of health. In other words, by understanding the microcosmic-macrocosmic analogies we can learn from the visible (i.e. dream visions) about the invisible (i.e. the affections inside the body). ${ }^{103}$

Esses princípios universais aos que o autor se refere dependem, entretanto, de um

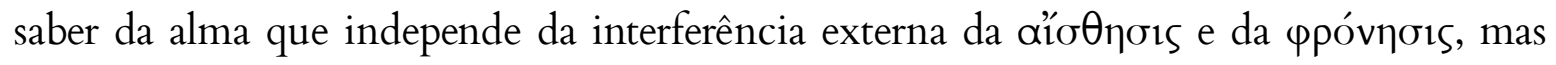
que subjaz como um conhecimento filtrado por esses canais e que, por isso, pode ter autonomia em relação a eles. Esse conhecimento é nomeado pelo nosso tratadista como $\gamma v \omega ́ \mu \eta$.

Essa $\gamma \vee \omega ́ \mu \eta$ partilha de um saber comum que nasce de um imaginário social que, por sua vez, determina um modelo de uma certa normalidade associada ao conceito de saúde e que pautará o processo de prodiagnose.

${ }^{103} 2014$, p.548-549 


\section{O Livro IV do Da dieta}

\subsection{Apresentação do tratado}

O livro IV do tratado Da dieta é composto de 7 capítulos que comportam imagens de sonhos relacionadas à prescrição dietética e ao prognóstico. É considerado o registro mais antigo de uma prática que, séculos mais tarde, teria profícua produção, notadamente, com a Onirocrítica de Artemidoro, que data do segundo século da nossa Era. Embora essa prática estivesse relacionada - já desde os catálogos de sonhos pitagóricos dos quais não temos vestígios - à esfera mística e religiosa, principalmente nos rituais de incubação do culto a Asclépio ${ }^{104}$, o nosso tratadista coloca essas imagens -

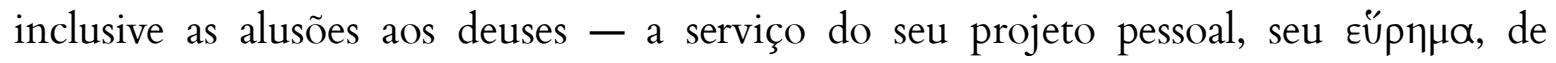
estabelecer um método de prodiagnose com o fim de evitar doenças e, assim, manter a saúde.

No início do livro, o capítulo 86 (do conjunto Da dieta), o autor explica como é possível, a partir dos sonhos, chegar a informações acerca de condições do corpo que não são evidentes e que, de outra forma, manter-se-iam inalcançáveis pela visão. Explica o autor que, durante o sono, enquanto o corpo descansa, a alma permanece ativa e tudo conhece. Ela, por si só, realiza todas as ações que realizaria em conjunto com o corpo acordado, tais como ver, ouvir, caminhar, tocar, sentir e pensar.

No sono, embora haja ainda percepção da alma, não há percepção relacionada à đîợđors do corpo, ou seja, não há sensações no corpo vindas de fora. De acordo com Cambiano ${ }^{105}$, o que acontece durante o sono é uma mudança na percepção. Uma vez

\footnotetext{
104 cf. Lee T. Pearcy, "Writing the Medical Dream in the Hippocratic Corpus and at Epidaurus". In: Oberhelman, 2013, p.93.

105 Cambiano, G., "Une interpretation 'materialiste' des rêves: Du Regime IV”. In Grmek, M. D. (Ed.). Hippocratica: Actes du Colloque Hippocratique de Paris. Paris: 1980, p.93.
} 
que o sono impede que haja alguma conexão entre a alma e o mundo exterior, o objeto de percepção da alma acaba sendo o corpo mesmo e tudo o que ocorre dentro dele. Essa questão parece ser clara para o nosso autor, que, no capítulo 71 do livro III, explica

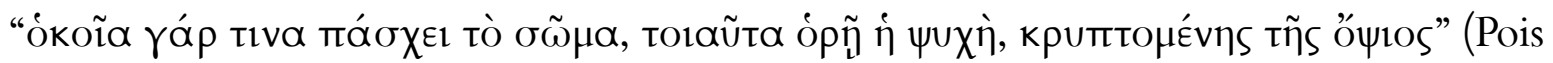
tudo o que o corpo sofre, essas coisas a alma vê, estando a vista escondida). De todos modos, o autor não oferece maiores explicações a respeito do funcionamento dos sonhos, nem como as representações alegóricas se relacionam com o que acontece de fato no corpo.

No início do capítulo 87, o autor explica haver diferentes tipos de sonhos:

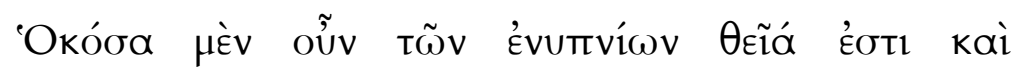

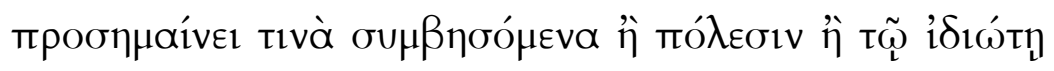

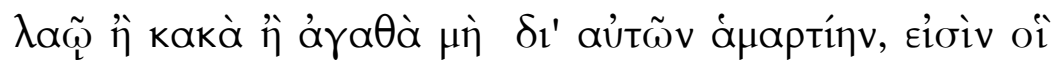

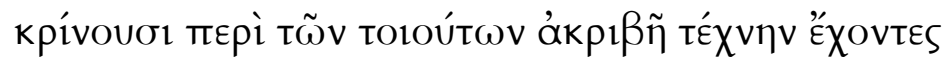

Todas as coisas que em sonhos são divinas e prenunciam males ou bens ou às cidades ou ao povo particular, e não por erro deles, há quem julgue a respeito deles com uma

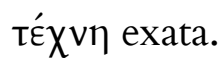

O que o autor deixa claro aqui é que esse tipo de sonho pertence a um outro fazer, a uma outra $T E ́ \chi v \vee \eta$, que possui um saber próprio e quem o maneje. Entretanto, ao

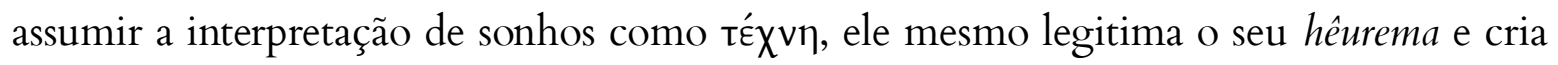

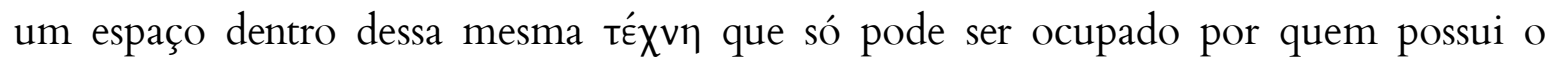
conhecimento preciso da medicina. Porém, de acordo com o autor, esses mesmos

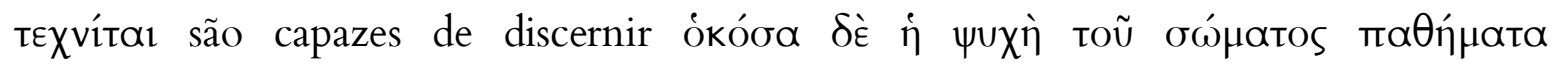

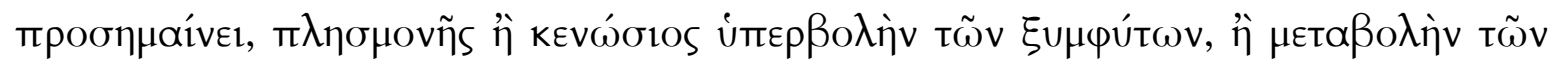


àn $\theta \varepsilon ́ \omega v$ (todas as coisas [nos sonhos] em que a alma prenuncia afecções do corpo, excesso de repleção ou de esvaziamento do que é inato, ou mudança do que é inabitual).

Embora esses intérpretes de sonhos que não pertencem à esfera médica tenham a capacidade de ver algo que esteja errado, eles não têm a habilidade médica para tomar as devidas providências profiláticas ou terapêuticas, e podem tão-somente ajudar com conselhos mais genéricos ou com súplicas aos deuses.

No capítulo 88, o autor introduz o princípio através do qual todas as imagens de sonhos devem ser interpretadas, guiado por um $\tilde{\eta} \theta$ os. Assim, a similaridade das imagens com o que é habitual é considerada como algo bom, já a dissimilaridade é considerada como algo ruim. Assim, se o corpo estiver em situação saudável, os sonhos com as ações diurnas acontecem conforme foram, ou seja, refletindo uma realidade. A equivalência direta entre a realidade diurna e sua imagem onírica parecem sugerir aqui também uma relação entre a normalidade e saúde; porquanto a alteração da realidade no sonho, ou a distorção do real no campo onírico revela uma distorção simétrica no estado normal do corpo. Tal distorção, se não é necessariamente antagônica à saúde, ao menos dela destoa, oferecendo um $\sigma \tilde{n} \mu \alpha$ à prodiagnose ou até mesmo à diagnose. Se, portanto, houver algo errado com o corpo, as imagens nos sonhos são diversas das ações diurnas, e, dependendo da intensidade dessas imagens, o mal que acomete o corpo terá igual proporção.

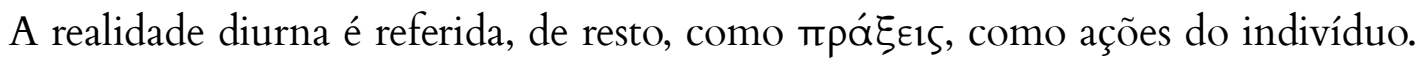
São essas ações que o tratado espera ver refletidas ou representadas no sonho, que é, em última instância, um rá⿴囗os (ainda que não seja assim nomeado no tratado). Trata-se,

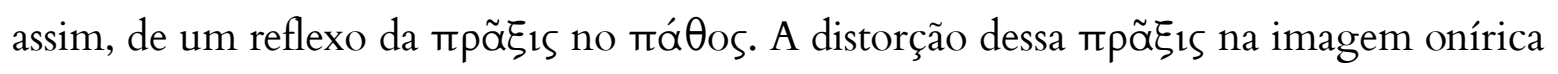
reflete uma quebra da cadeia entre ação e reação que indica que algo inesperado - ou

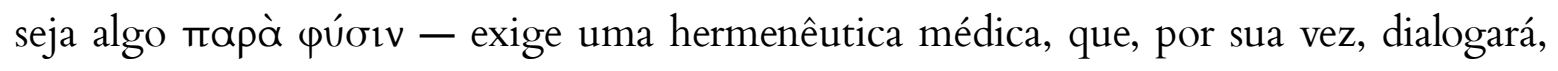
no campo da cultura, com a leitura proposta pela tradição mântica.

Feito o diagnóstico para a adulteração da realidade no sonho, o tratamento proposto pelo médico tratadista é purgar e equilibrar o corpo com alimentos leves e exercícios proporcionais à ministração do alimento, para que o excesso indicado pelo 
sonho seja eliminado. O distúrbio, então, é interpretado como fruto de uma superabundância, de alguma coisa da esfera do "hyper-", para a qual só há duas respostas médicas possíveis: a purgação e o móvos, o esforço forçado por mando ou com fim específico, algo, enfim, concernente ao campo da dieta.

A ideia presente no capítulo 88 é também explorada nos capítulos 89 e 90, que relaciona os reflexos oníricos das imagens do real a uma normalidade que parece estar diretamente relacionada à saúde, e considera a distorção dessas imagens um indício de estado patológico. Essa similitude sêmica, oscilante entre a prodiagnose e a diagnose, não deixa de ser resultado de operações mentais de analogia que constroem vínculos entre a ordem micro e macrocósmica, que fora pormenorizada nos capítulos 9-10 do livro I.

No capítulo 89, que trata da aparência e movimento dos astros celestes, o autor expõe o funcionamento dos princípios de normalidade e anormalidade: ver os fenômenos celestes como eles são significa saúde, enquanto que ver algo diferente disso significa alteração ou mesmo doença. Para tanto, explica as relações das órbitas com os circuitos internos do corpo correspondentes. Para além do liame estabelecido entre o macro e o microcosmo, aquele do corpo, fica, nessa passagem, esclarecida a equivalência entre a saúde e a normalidade, se tal normalidade for entendida aqui como a percepção de uma realidade correspondente a uma expectativa.

As imagens de sonhos mais específicas estão ligadas às várias condições do corpo, e aqui, o tratadista oferece um tratamento acorde. A forma com a qual a anormalidade é interpretada revela não só como o autor discerne a importância dos diferentes tipos de imagens, mas também como o tratamento é oferecido de acordo com o pano fundo teórico por ele exposto no restante do livro. O autor menciona a correspondência dos

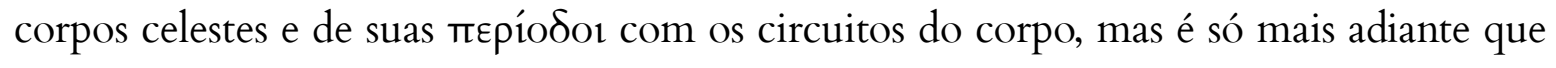
é possível ver correlações adicionais. As imagens relacionadas ao mar, para citar alguns exemplos, têm correspondência com o movimento dos intestinos; as imagens da terra, com a carne, ou as imagens de regiões altas têm relação com a cabeça. Além disso, podemos encontrar referências a outras teorias médicas, como a alusão aos humores 
(curiosamente não mencionados em outras partes do tratado) e suas potenciais influências na saúde do indivíduo quando excessivos no corpo, ou a alusão a fluxos, à

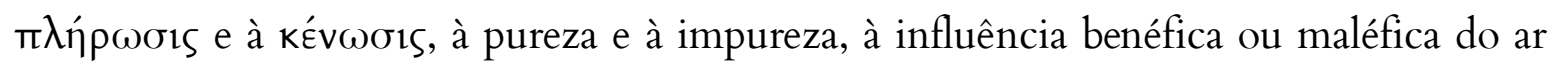
externo, etc.

Ao analisar-se os tratamentos recomendados pelo autor, que são baseados nas imagens dos sonhos, pode-se ver a proposição micro-macrocósmica aplicada à maioria dos casos. Alguns exemplos disso estão no capítulo 89:

- um problema no circuito externo é resolvido por uma revulsão externa;

- um problema no circuito interno, por uma revulsão interna;

- um problema no circuito mediano, por ambas revulsões, interna e externa;

- sequidão e presença de bile podem ser compensadas por medidas para umedecer o corpo;

- para angústias da alma, recomenda-se ver espetáculos que façam rir;

- a impureza no corpo é solucionada por uma purgação.

No final do capítulo 89, o autor faz uma lista de deuses a quem é preciso suplicar: a Hélio, a Zeus celeste, a Zeus do Lar, a Atena do Lar, a Hermes a Apolo e também àqueles a quem o texto considera seus contrários ('̇vóvtıo1), a Gaia e aos Heróis. A respeito da presença desses deuses, Van der Eijk argumenta:

As to the identity of the gods mentioned here, the reference to 'celestial' deities such as Helios and Zeus Ouranios, and perhaps that of Apollo, makes good sense considering the 'celestial' contents of the dreams and their correspondence with the microcosmic system of bodily circuits. Zeus Ktesios and Athena Ktesie are invoked probably because of their general protective capacity with regard to a person's private life and livelihood. As to Hermes, who is mentioned again later on, his presence here is to be explained perhaps 
not so much because of his status as provider of dreams (the relevance of which is dubious in the light of the author's belief in the physical origin of the dreams he is dealing with), but more likely because of his ambivalent role as a mediator between life and death. The latter presumably also explains the invocation of the other 'chthonic' deities Earth and the Heroes. ${ }^{106}$

Apesar de a presença dos deuses aqui haver sido compreendida pela tradição como um resquício ${ }^{107}$ - ou mesmo uma cópia - de práticas textuais anteriores, como catálogos de sonhos, é necessário notar que há aí uma coerência com o que foi dito anteriormente pelo tratadista, em especial no capítulo 87, em que ele argumenta: "é bom suplicar aos deuses, mas deve-se evocar os deuses fazendo o que lhe cabe", ou seja, cuidar também da saúde. As variadas interpretações dessa passagem indicam com bastante clareza as posições dos tradutores da obra. De fato, tal passagem reanima questões pulsantes desde, pelo menos, a edição (e tradução) de Émile Littré, em 1849. Arrolando as traduções vernaculares disponíveis tem-se:

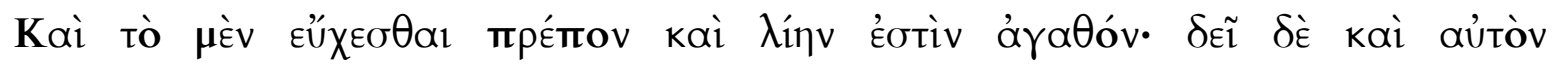

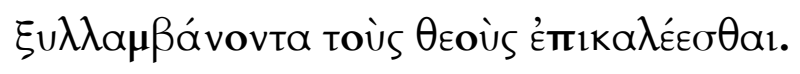

Littré: "Prier est sans doute chose convenable et excellente; mais, tout en invoquant les dieux, il faut s'aider soi-même”.

Jones: "Prayer indeed is good, but while calling on the gods a man should himself lend a hand".

\footnotetext{
${ }^{106}$ Van der Eijk, 2004, p.204.

${ }^{107}$ Palm, 1933, apud Joly \& Byl, 1984.
} 
Joly: "Prier est une bonne chose, mais, tout en invoquant les dieux, il faut s'aider soi-même".

García Gual: "Cierto que invocar a los dioses es bueno; pero conviene invocar a los dioses y ayudarse a si mismo".

Jouanna $^{108}$ : "Prier est sans doute une bonne chose; mais, tout en invoquant les dieux, il faut aussi prendre sa part”.

As traduções de Joly e Jones seguem a letra de Littré, que entende o "ajudar" como um contraponto à prescrição de evocar os deuses. Nessa interpretação há duas questões a serem consideradas: em primeiro lugar, o verbo impessoal $\delta \varepsilon \tilde{e}$, cujo complemento é um infinitivo, é transposto para a reduzida de particípio, ignorando o infinitivo que lhe segue. Dessa forma, muda-se o sentido da frase, transladando a obrigatoriedade implicada por esse verbo ao sintagma "ajudar a si mesmo", no lugar de "evocar os deuses", como seria correto, como uma tentativa de esvaziar o texto de um suposto caráter religioso, como é de praxe nas interpretações tradicionais do início do século XX para textos da antiguidade, que procuram secularizar a medicina antiga.

O capítulo 90 trata da terra e dos elementos ligados a ela, e é possível ver uma continuidade com as analogias micro-macrocósmicas. Num primeiro momento, o autor expõe uma série de sinais que podem ser interpretados como favoráveis. Novamente, o conceito de normal e patológico, associado às qualidades bom e mau, salta aos olhos. Entretanto, quando se trata de definir uma ideia de saúde ao evocar tais imagens, parece haver uma qualidade que ultrapassa o estado de normalidade e que pode indicar uma procura por uma certa excelência. É possível observar um exemplo disso quando o autor

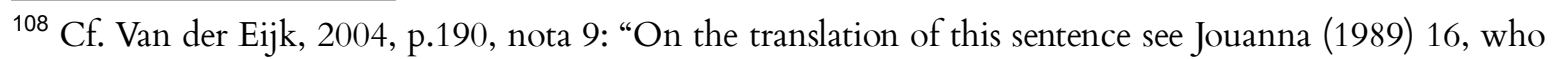
points out that aútóv cannot be the object of $\sigma u \lambda \lambda \alpha \mu \beta a$ vovta since this would require a dative aút $\omega$ or Éaut $\omega$. He translates the sentence as follows: 'Prier est sans doute une bonne chose; mais, tout en invoquant les dieux, il faut aussi prendre sa part', and he paraphrases this latter phrase to mean 'aider les dieux tout en les invoquant', i.e. 'l'homme doit apporter ses moyens, aussi faibles soient-ils, pour faciliter la réussite de l'action divine'. This latter paraphrase goes a bit too much beyond what the text says, as the author elaborates on dietetics but does not go into the modalities of divine action."
} 
explica que correr com segurança e sem medo e ver a terra bem trabalhada e as árvores frondosas e com frutos são sinais de saúde. Portanto, enquanto a normalidade é algo evidentemente bom, essas imagens carregam em si um elemento extra que ultrapassa esse padrão. Um estado de anormalidade, segundo o autor, é o oposto disso.

Segue-se a essas imagens uma lista de elementos que indicam um estado de anormalidade e adoecimento. É possível observar novamente uma intrincada teia de analogias entre as imagens macrocósmicas dos sonhos com o espectro microcósmico do corpo. Assim, bem como no capítulo 89, a terra está relacionada à carne; árvores sem frutos indicam problemas de fertilidade; rios e seus fluxos têm relação com a circulação do sangue; poços e fontes - da mesma forma que o mar no capítulo 89 - se relacionam ao ventre. Ver a terra ou a casa em movimento pode ser um indício de saúde ou adoecimento geral, relacionando-se com a mudança de um estado a outro. Ver a terra inundada ou queimada pode ser indício de excesso de umidade ou sequidão no corpo. $\mathrm{O}$ autor oferece tratamento baseado nos princípios já apresentados no restante do tratado: enquanto o úmido e frio são neutralizados pelo seco e quente, o contrário também se aplica. $\mathrm{O}$ excesso é tratado pelo esvaziamento, e, na presença de algo não

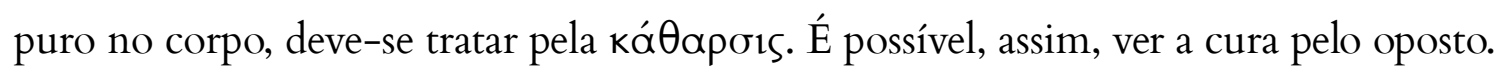

Até aqui, a relação analógica micro-macrocósmica pautou a interpretação das imagens dos sonhos, mas o que se lê do capítulo $91 \mathrm{em}$ adiante parece ser de natureza mais simbólica e do âmbito exclusivo do $\tilde{\hat{\eta}} \theta$ os. O capítulo 91 trata das vestes e indica as cores que sinalizam saúde ou doença. Uma veste branca, com belíssimas sandálias, todas na medida certa do corpo é o que o autor considera ser normal, e, portanto, ver essas imagens em sonho é igualmente bom e um sinal de saúde. Vestes pretas e novas, maiores ou menores que o corpo, indicam doença.

No capítulo 92, cujo assunto trata dos mortos, o autor afirma que a partir do que está morto vem a nutrição, o crescimento e as sementes. Em seguida, explica que se quem sonha os vir puros e em vestes brancas e receber deles algo também puro, isso significa que o corpo está saudável e que algo puro entrou nele. Novamente, é possível 
ver que a norma não só se estabelece a partir do que é bom, mas também é possível observar os elementos simbólicos e do âmbito do $\tilde{\eta} \theta$ os, tais como as vestes brancas. A descrição seguinte é do oposto disso: se quem sonha vir os mortos nus ou com vestes pretas e não puros, isso é um mau sinal e significa que algo impuro entrou no corpo e é necessário purgar, a partir de corridas, caminhadas e vômitos, além de uma dieta leve.

O capítulo 93 consiste de uma série de imagens de teor relativamente diferente das anteriores. Ao longo do capítulo, é possível notar uma diversidade que, aparentemente, não constitui uma única unidade temática, mas diferentes assuntos agrupados no mesmo capítulo. Não há muitos dados a respeito da natureza desse capítulo, portanto seria uma conjetura arriscada dizer que talvez se trate de excertos que a princípio não comporiam um capítulo inteiro, como o fazem Palm e Friedrich ${ }^{109}$. Porém, as evidências textuais não são suficientes para tal análise. É possível, entretanto, apontar alguns indícios que apontem essa diversidade temática.

Começa o autor, assim, por uma associação um tanto curiosa: ver imagens que aterrorizem o homem significa excesso de alimentos não assimilados no corpo, secreção, fluxo bilioso e uma doença perigosa. A relação entre as imagens e o seu significado é um tanto obscura. A primeira associação pode ser interpretada a partir dos dois qualificativos à $\lambda \lambda$ ó periculosidade da doença indicada pelas imagens também entraria nessa associação. Já a presença de secreção ou bile não tem aparente relação com a imagem, e qualquer associação seria mera conjetura da minha parte. $\mathrm{O}$ tratamento indicado, entretanto, parece ser adequado, no sentido de que segue a lógica do restante do tratado, em que uma prescrição de purgação seguida de uma dieta leve é indicada em caso de excesso.

No parágrafo seguinte, o autor prossegue com a descrição de imagens que denotam um desejo do corpo ou da alma. Se, em sonho, quem sonha parece comer alimentos com os quais habitualmente se alimenta, isso significa falta de alimento e desejo da alma. Comer carnes fortes em sonho significa um grande excesso, e comer $\overline{{ }^{109} \text { Cf. Harris, 2009, p.248. }}$ 
carnes fracas, um excesso menor. A lógica por trás disso o autor explica: se o que se come estando acordado é bom, ao ver-se em sonho comer a mesma coisa é também bom, e vice-versa. A ideia central aqui é que se deve comer menos porque há um excesso - o oposto do desejo - de nutrição, e é exatamente isso que o autor prescreve. A mesma ideia também se aplica ao tratamento dos sonhos quando se trata de, em sonho, comer pão com queijo e mel. Mais adiante, também, o autor explica que beber água pura em sonho não é prejudicial, mas beber outros tipos de bebida, sim. A passagem, entretanto, não é muito clara e as edições, discrepantes. É possível, novamente, observar o princípio normal-bom, anormal-ruim. Tendo oferecido a explicação do que significa comer e beber em sonho, em relação ao que viria a ser um desejo da alma, o autor explica que não só as imagens de alimentos e bebidas, mas esse desejo também é indicado ao se ver qualquer coisa de habitual durante o sono.

As quatro imagens seguintes mostram alguma similaridade com a primeira imagem do capítulo, no sentido de que pertencem à mesma esfera - a dos circuitos do corpo, tendo também tratamento similar. Assim, fugir amedrontado indica interrupção do sangue pela sequidão, cujo tratamento se dá através do umedecimento e esfriamento do corpo. Combater, ser espetado ou acorrentado por outro significa que houve uma

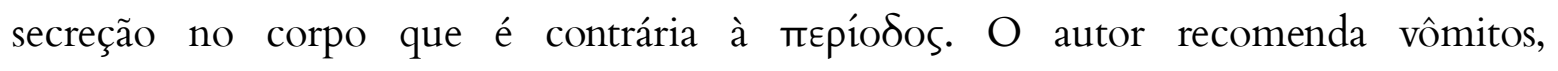
emagrecimento, caminhadas e comidas leves, tratamentos que, de resto, podem ser encontrados no resto do tratado ${ }^{110}$. Atravessar rios, ver hoplitas, inimigos ou monstros de formas estranhas significa doença ou loucura ( $\mu$ avín). O tratamento recomendado para sonhos desse tipo é um pouco difícil de entender: o paciente deve comer pequenas quantidades de comida mole e leve, e vomitar. Tendo feito isso, o alimento deve ser ministrado gradativamente durante cinco dias; deve fazer exercícios naturalmente, exceto depois do jantar. Deve evitar tomar banhos quentes, descansos, o frio e o sol - todos eles, deve-se notar, foram recomendados na primeira imagem do capítulo. As prescrições são

\footnotetext{
$\overline{110}$ Cf. Da dieta III, 71 e 88.
} 
de difícil compreensão, por não haver no texto indício de explicação sobre o que o autor entende do que ocorre no corpo.

O que parece evidente, entretanto, é que o autor vê a correlação entre o modo como algo é representado e o significado do sonho para quem o sonha. $\mathrm{O}$ autor parece compreender que a interpretação dos sonhos é um grande auxílio -- talvez o maior de todos -- para poder criar uma dieta delineada especificamente para a saúde e para, assim, poder levar uma vida sem doença. Lê-se no final do tratado: "Fazendo uso dessas coisas,

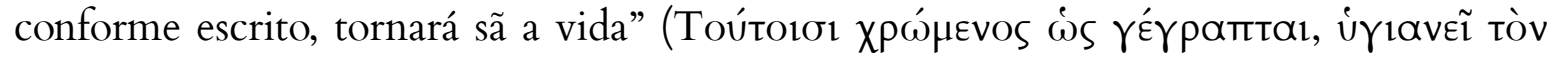
Bíov).

Em sonhos, a alma oferece sinais a serem interpretados e advertências de quaisquer problemas relativos ao corpo. Se o médico souber interpretar corretamente a leitura dos sonhos, isso the permitirá formular sua prodiagnose, uma avaliação da condição do paciente e uma identificação dos excessos no corpo das propriedades que o compõem, antes que a doença possa se manifestar.

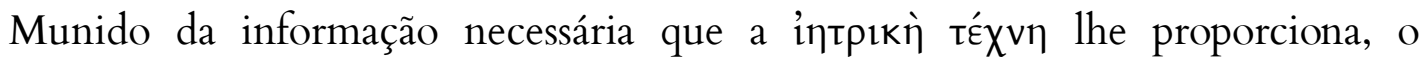
médico pode prescrever a dieta do paciente com mais correção (ỏ $\theta \tilde{\omega} \varsigma)$, dependendo das necessidades do corpo. No entanto, essa prodiagnose não proporciona uma indicação exata de uma doença específica. Com respeito a isso, Philip van der Eijk explica que

It is striking that the author is using a very descriptive, if not rather 'primitive' nosology: technical terms for diseases, e. g. phrenitis, pneumonia, ileus etc. are absent, and the terms in which the author's pathology is cast - belly, blood, flesh, 'periods' - are very similar to those he used in his anatomical and physiological theories in Books 1-3. ${ }^{111}$

\footnotetext{
$\overline{111 \text { Van der Eijk 2004, p.202 }}$
} 
Se, entretanto, considerarmos que o autor afirma expor a sua própria descoberta, não é surpresa não encontrarmos nomes de doenças no tratado, uma vez que a partir da interpretação, o médico depreende a condição do corpo do paciente e os efeitos dos alimentos e dos exercícios a partir disso. O autor do Prognóstico, coincidentemente, afirma no final do seu tratado que

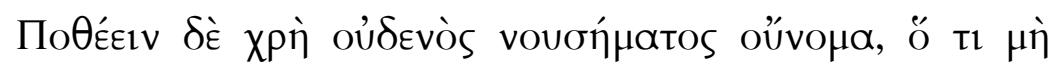

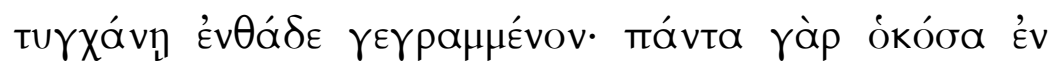

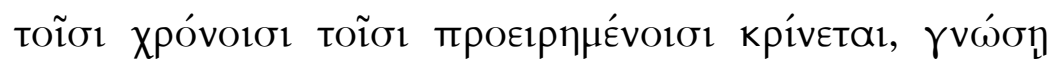

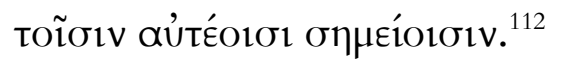

Não é preciso desejar nenhum nome de doença, que por ventura não esteja aqui escrito. Pois todas as [doenças] que nos tempos anteriormente falados forem discernidas, conhecerás pelos mesmos sinais.

Segundo Jouanna ${ }^{113}$, o método do prognóstico permite que o médico, através da observação e interpretação de todos os sinais, possa transcender a diversidade das doenças - manifesta pela diversidade dos seus nomes. Essa postura parece alinhar-se à do nosso tratadista, cujo recorte pressupõe um estado de saúde que possibilite uma prodiagnose por meio dos sonhos.

112 Prognóstico, 25, 5

${ }^{113} 2013$, p.80, nota 1 . 


\subsection{Tradução do Livro IV ou Sobre os sonhos}

\section{Nota filológica}

As edições modernas do tratado Da dieta utilizadas para a confecção da tese são as de Robert Joly, da Ed. Les Belles Lettres, de 1967, a de W.H.S. Jones, da Loeb, de 1931, e a de Émile Littré, de 1863-77, que têm por base os manuscritos Vindobonensis medicus gr. 4, séc. XI. ( $\theta$ ); Marcianus gr. 269, séc. X. (M); Parisinus gr. 2142, séc. XIIXIII. (H); Parisinus gr. 2143, séc. XIV (J) e Parisinus gr. 2140, séc. XV (K). 


\section{Da dieta IV ou Sobre os sonhos}

86

1. Sobre as evidências ${ }^{114}$ produzidas nos sonos quem as depreendeu corretamente descobrirá que elas têm grande propriedade sobre o todo. Pois a alma, estando a serviço ${ }^{115}$ do corpo desperto, dividindo-se em muitas coisas, não é ela de si mesma, mas atribui uma parte a cada [faculdade] do corpo, à audição, à vista, ao tato, ao caminhar e às ações de todo o corpo; mas a mente nunca é de si mesma.

2. Quando o corpo se tranquiliza, a alma, em movimento e desperta, administra seu próprio domínio ${ }^{116}$ e realiza ela mesma todas as ações ${ }^{117}$ do corpo. Pois o corpo, adormecido, não sente, mas ela, desperta, conhece todas as coisas: vê o que é visível, ouve o que é audível, caminha, toca, sente dor, pondera, no pouco que lhe cabe; todas as

114 Note-se o uso de vocabulário jurídico, que aparece empregado em inúmeras partes do tratado. Tal repetição constante do termo sugere uma referência, um uso de elementos que pertencem à prática

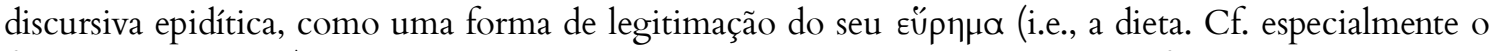
final do capítulo 93). Não é coincidência encontrarmos, na escrita historiográfica herodotiana e, em específico, na tucididiana, que o conhecimento dos acontecimentos do passado vem sempre expresso através do verbo eúpírkw (Cf. Butti de Lima, 1996, p.136-137). Nessa linha, é preciso ressaltar o uso

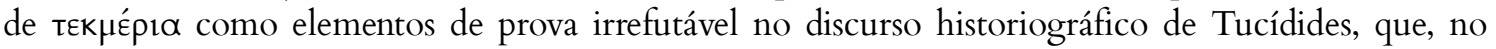
proêmio à sua Guerra do Peloponeso propõe escrever a guerra a partir dos tєкцépı que ele acha dignos de fé (1.1.1). Neste texto, é curioso notar que o autor associa os тєкце́pia ao resultado físico, i.e., o sintoma, dado pelos ón $\mu$ ata dos sonhos. Aristóteles, em Retórica 1402b, examina as partes do

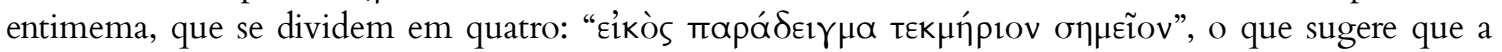
noção já fizesse parte de um saber retórico, que, embora não institucionalizado à época do nosso autor, parecia compartilhar dos termos e conceitos mais tarde apropriados pelo estagirita.

115 Verbo empregado no ambiente domestico, principalmente escravagista, com sentido de servir. O LSJ

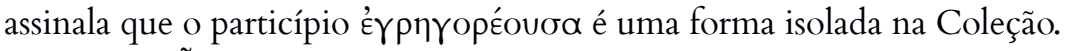

116 O termo ỡkos aqui é apontado por Palm (apud Joly, 1967) como uma ressonância da doutrina da atividade da alma órfico-pitagórica. Joly aponta que o termo ỡkos e oíkẽ̃v é utilizado em contextos místicos ou escatológicos, uma vez que o sono, nesse contexto, é uma imagem ou antecipação da

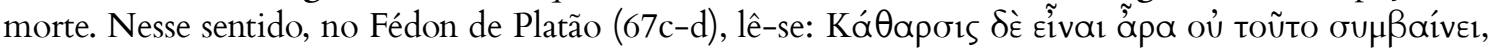

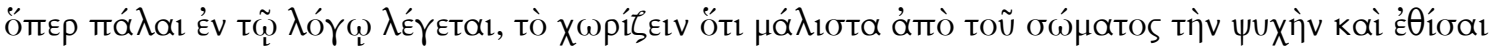

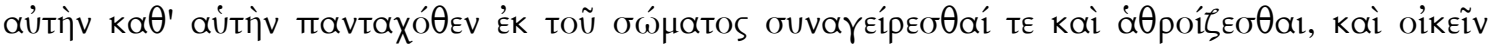

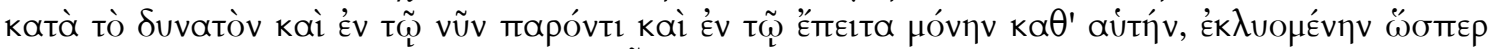

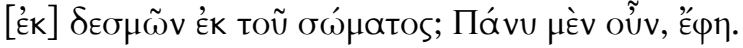

117 Trata-se, aqui, de um Objeto direto interno do verbo $\delta$ 1ampá $\sigma \sigma \omega$. Note-se a insistência do uso de $\pi \rho \tilde{a} \xi_{1 \zeta}$ como uma oposição a úrrvos. 
funções do corpo ou da alma, todas essas coisas a alma realiza no sono. Assim, quem sabe discerni-las corretamente, sabe grande parte da sabedoria ${ }^{118}$.

87

1. Todas as coisas que em sonhos são divinas e prenunciam males ou bens ${ }^{119}$ às cidades

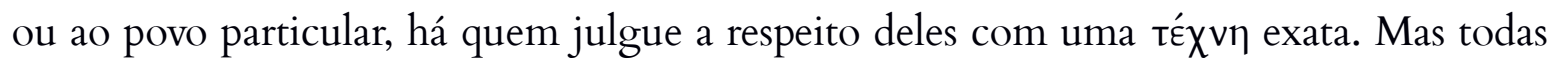
as coisas [nos sonhos] em que a alma prenuncia afecções do corpo, excesso de repleção ou de esvaziamento do que é inato, ou mudança do que é inabitual ${ }^{120}$, também as discernem.

2. Algumas vezes por sorte acertam, outras erram, mas em nenhum dos dois casos sabem por aquilo que as coisas são, nem quando acertam, nem quando erram, aconselhando preservar-se para não sofrer algum mal. Mas esses não ensinam como se deve preservarse; mas mandam rogar aos deuses. Rogar também é bom, mas é preciso invocar os deuses também ajudando a si mesmo.

88

1. Sobre isso, é assim: todas as coisas que em sonhos propiciam as ações diurnas do homem, ou pensamentos voltados para a razoabilidade, como de fato são, da mesma forma em que durante o dia foram realizados, ou que são inspirados por uma ação justa ${ }^{121}$, são esses bons para o homem, pois indicam saúde, porque a alma permanece nos

118 Joly (1967, p.115) aponta que o uso de oopía no sentido de um saber específico é particular de textos do século V, muito mais do que do século IV. Essa constatação possibilita ter uma aproximação da datação estimada do tratado, que o coloca entre o ultimo quarto do século $\mathrm{V}$ e o primeiro do IV.

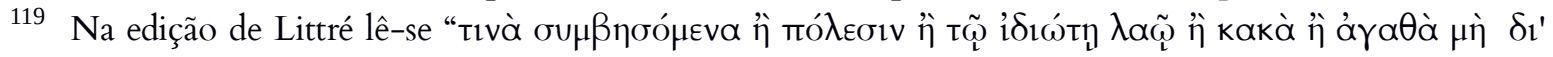

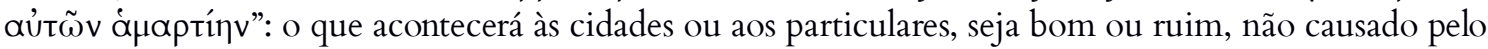

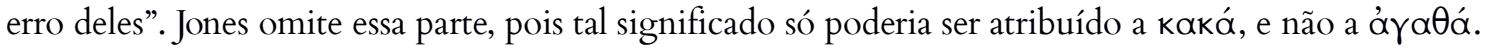

120 Aqui, parece haver um paralelo a $\tau \tilde{\omega} v \xi \cup \mu \varphi \cup ́ \tau \omega v$, da mesma natureza, o que, por um lado, poderia ser entendido como o alimento que entra no corpo e é assimilado (entendido pelo autor como parte do

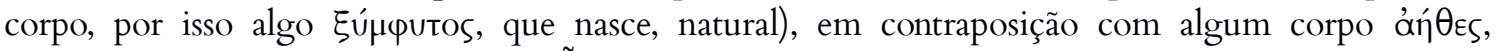
estranho e não habitual, do campo do $\tilde{\hat{\eta}} \theta$ os.

121 Novamente, vocabulário jurídico. Indica, possivelmente, um viés ético da dieta. Joly, entretanto, traduz

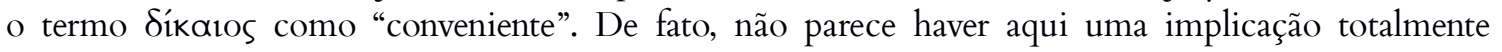
jurídica, porém o uso do vocábulo salta aos olhos, considerando como tal termo ressoaria diante de 
propósitos $^{122}$ diurnos, não dominada pela repleção, nem pelo esvaziamento nem por outra circunstância externa.

2. Quando os sonhos são o contrário das ações diurnas, e neles há um combate ou uma querela, significa uma perturbação no corpo. Se for forte, o mal é forte, mas se for vil, a perturbação é mais fraca. Sobre a ação, se é preciso preveni-la ou não, não julgo ${ }^{123}$; mas recomendo o tratamento do corpo. Pois proveniente de uma repleção, surge uma secreção que perturba a alma. Se, então, a oposição for forte, é caso de provocar vômito e ministrar por cinco dias alimentos leves e fazer uso de muitas e caminhadas matutinas em ritmo rápido, exercitando-se com exercícios graduais de acordo com a ministração dos alimentos. Se a oposição for mais leve, reduz os vômitos em uma terça parte em relação aos alimentos, e ministra-os suavemente de novo durante cinco dias. Forçar as caminhadas, fazer uso de esforços de voz e rezar aos deuses ${ }^{124}$, e a perturbação cessará.

1 [Ver] o sol, a lua, o céu e os astros puros e brilhantes, como se os vê, é bom, pois significa saúde do corpo a partir de tudo que existe. Mas é preciso salvaguardar esse estado $^{125}$ com a dieta aqui apresentada. Mas se um desses for contrário, significa uma doença para o corpo, a partir do que é mais forte, uma doença mais forte, e a partir do

uma possível audiência, bastante acostumada ao tribunal políade.

${ }_{122}$ Observar que é a mesma raiz de $\beta o u \lambda \varepsilon ́ v \omega$, indicando que o corpo permanece com o propósito inspirado pela ação razoável.

${ }^{123}$ Embora esse verbo seja traduzido no restante do texto como "discernir", aqui, parece-me mais adequada a tradução por julgar. O autor, aqui, aparentemente, tenta se eximir de um julgamento moral a respeito das particularidades das ações, mas concentra-se no resultado que delas vem.

124 Joly, fiel ao seu manuscrito base Vindobonensis medicus gr. IV (do séc. IX), mantém a expressão kaì

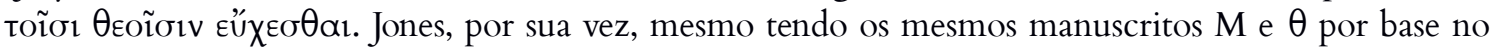
seu estabelecimento, opta por omitir essa passagem, que consiste na primeira referência às preces aos deuses no livro IV. Apesar da opinião de Joly (1967, p.99, n.3), tal menção parece estar bem de acordo com a posição que os deuses ocupam nos demais tratados coicos, em especial o Da doença sagrada. Não se pode negligenciar a possibilidade de Jones estar imbuído de uma leitura laicizadora ou dessacralizadora do $\mathrm{CH}$; o que é mais surpreendente, no entanto, é que nem mesmo Littré (que coloca

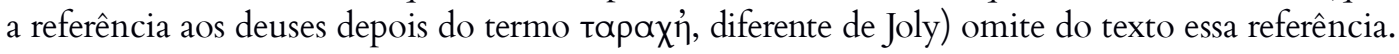

${ }^{125}$ A palavra $\dddot{\eta} \xi_{1 \zeta}$ nos tratados hipocráticos geralmente tem o sentido de "compleição". Nessa passagem, pareceu-me, graças ao contexto, mais adequado utilizar o termo "estado" para interpretá-la. 
que é mais fraco, uma doença mais leve.

$2 \mathrm{O}$ circuito externo é próprio dos astros, o mediano é próprio do sol e o mais próximo à cavidade ${ }^{126}$ é próprio da lua. Então, se algum dos astros for prejudicado, desaparecer ou for impedido no seu circuito, seja pelo ar ou por uma nuvem, é mais fraco. Se for por água ou por granizo, é mais forte. Significa que há uma secreção no corpo úmida e fleumática no corpo que sobrecaiu sobre o circuito externo.

3 É o caso de fazer uso de muitas corridas com vestes, ministrando-as aos poucos, de modo que transpire o máximo possível, e fazer uso de muitas caminhadas após os exercícios e suprimir desjejum. Reduzindo a terça parte dos alimentos, ministrá-los gradualmente em cinco dias. Se parecer ser mais forte, fazer uso de banhos de vapor, pois é caso de fazer a purgação através da pele, porque o nocivo está no circuito externo ${ }^{127}$. Fazer uso de alimentos secos, acres, adstringentes e sem mistura, e esforços que sequem o máximo possível.

4 Se ocorrer com a lua qualquer dessas coisas, é caso de fazer a revulsão para dentro ${ }^{128}$, fazendo uso de vômitos a partir de alimentos acres, salgados e suaves e de corridas circulares rápidas e de caminhadas; de esforços de voz ${ }^{129}$, supressão do desjejum, e também supressão de alimentos e ministração [progressiva] da mesma forma. Por isso a revulsão para dentro, porque o mal apareceu nas cavidades do corpo.

${ }^{126}$ Esta ocorrência do termo koĩ $\lambda \alpha$ é a única em que tal termo (ou qualquer de seus cognatos) se refere aos astros. Parece-me claro que, como lembra García Gual (1986, p.108, nota 93), tal uso destaca a equivalência semiológica entre o macro e o microcosmos, que fora minucizada no capítulo 10 do livro I. Joly, sem estender seu comentário a nota de rodapé, acresce à tradução um parêntese ("de la sphère interieure"), sugerindo, a meu ver, que o termo tenha conotações especificamente macrocósmicas.

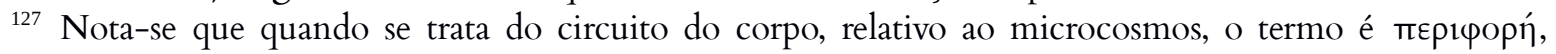

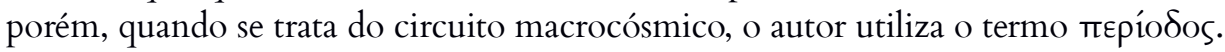

${ }^{128}$ De acordo com Joly (1967, p.101 n.1) “a revulsão para o interior é um procedimento que é utilizado para movimentar os humores no ventre através dos vômitos. A revulsão para o interior se explica, nesse caso, pelo fato de que é à lua que concerne a revulsão mpòs tò koĩ $\lambda \alpha$ ". Além de nessa passagem, esse procedimento aparece no capítulo 56.

129 Littré omite tpóxoı dirigida para o interior e não poderia se ajustar a uma atividade dirigida ao exterior. Entretanto, no final do capítulo 32 do livro I, é possível ver uma prescrição de exercícios destinados ao interior do corpo, o que vai de encontro à interpretação de Littré. Joly aponta ambas passagens como "obscuras" (tanto essa quanto a do cap. 32), encerrando qualquer especulação a seu respeito. 
5 Se ocorrer com o sol algo desse tipo, isso já é mais forte e mais difícil de eliminar. Deve-se fazer a revulsão nas duas direções e fazer uso de corridas simples, de corridas em pista dupla ${ }^{130}$ e de corridas circulares, de caminhadas e de todos os outros esforços, e a supressão e ministração dos alimentos de forma gradual. Logo, ao que vomitou, ministrá-los novamente em cinco dias.

$6 \mathrm{Se}$, estando o céu limpo, [o sol] for comprimido ${ }^{131}$, parecendo ser fraco e dominado pela sequidão da órbita, isso significa perigo de cair em doença. Então é preciso suprimir os exercícios e fazer uso de uma dieta úmida e mole, banhos, muito descanso e sono até melhorar.

7 Se o que se opõe parece ser ígneo e quente, significa uma secreção biliosa ${ }^{132}$. Se essas coisas dominam, significa doença. Se os dominados desaparecem, há perigo de morte advinda dessa doença. Se o que vem [em oposição] parecer se virar para a fuga e fugir rapidamente, com eles ${ }^{133}$ perseguindo-o, há perigo de o homem enlouquecer, caso não for tratado.

8 É muito melhor, para todos esses, fazer uma dieta depois de ter purgado com um heléboro ${ }^{134}$. Se não, é caso de fazer uso de uma dieta aquosa, não beber vinho, a não ser branco, leve, suave e aguado. Evitar alimentos quentes, acres, ressecantes e salgados. Que ele faça ${ }^{135}$ uso de exercícios de acordo com a natureza e em grande quantidade, bem

130 O termo кацтто̃̃oı é traduzido nos três textos cotejados ora por "outros exercícios" (Garcia Gual), ora por "corrida de fundo" (Joly), ora por "corrida em pista dupla" (Jones). Nenhum deles, no entanto, justifica as suas opções.

$131 \mathrm{O}$ sujeito não está expresso no texto grego, e pode referir-se tanto à lua, ao sol ou às estrelas. $\mathrm{O}$ termo á $\sigma$ Өvvéa, que pode ser tanto acusativo masculino ou feminino, ou mesmo um acusativo neutro plural - concordando com um tà áơtépa implícito - tampouco oferece resolução a essa questão. Todas as traduções consultadas, porém, consideram que o sujeito se refere aos astros, entretanto, como não houve prévia menção a eles, opto por discordar da opção de Jones, Joly e García Gual. Justifico a minha escolha pela presença de um pronome no acusativo masculino plural na seção 7, que jamais poderia se referir a tò ơớépa.

132 É rara a menção aos humores neste texto. Além da bile, também há referência ao fleugma.

133 Cf. nota 23. Toùs $\delta$ é. Sugiro, diferente de Joly, Jones e García Gual, que optam por inserir "os astros", mesmo não havendo menção ao termo no texto, considerar que o sujeito dessa frase se refere ao sol e à lua.

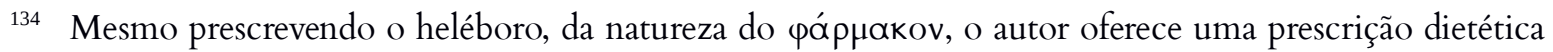
como alternativa, o que é consistente com o escopo da obra.

135 Note-se a passagem de verbos impessoais para verbos na $3^{\text {a }}$ pessoa do imperativo, o que pode ser um 
como corridas com veste ${ }^{136}$. Que não faça fricções, lutas e nem lutas no chão. Que durma muitos sonos em uma cama macia e que descanse exceto dos exercícios naturais. Que faça caminhadas depois de jantar. É bom também tomar banhos de vapor e vomitar depois do banho. Durante trinta dias, não se repletar. Quando o fizer, vomitar três ${ }^{137}$ vezes ao mês depois de alimentos doces, aquosos e leves.

9 Os que dentre esses vagam de um lado a outro, sem ser por necessidade, significa uma perturbação da alma por preocupações. É caso de divertir-se, como distrair a alma com espetáculos, principalmente com os engraçados; se não, com algo que provoque mais prazer de assistir, durante dois ou três dias, e se restabelecerá. Caso contrário, há perigo de cair na doença.

10 Se dos astros parecer cair da órbita algo puro e brilhante que parece levar algo para a aurora $^{138}$, é sinal de saúde. Se o que é puro no corpo é excretado do circuito, e por natureza vai da noite ${ }^{139}$ para a aurora, [isso] está correto. Pois o que é secretado do ventre e expelido da carne todo ele cai do circuito. Mas se um deles, escuro ou fraco parecer se dirigir para a noite, ou para o mar, para a terra ou para cima, isso significa doença.

11 Os que vão para cima [significam] fluxo da cabeça; os que vão para o mar, doenças do ventre; os que vão para a terra significam especialmente tumores ${ }^{140}$ que crescem na carne. É caso de, para esses, suprimir um terço do alimento, e ministrar aos que vomitaram por cinco dias, e em outros cinco introduzir o alimento por inteiro. E, vomitando, que ministre novamente do mesmo modo.

12 Se um dentre os astros celestes parecer aproximar-se de ti, estando puro e úmido, significa saúde, porque o que entra no homem a partir do éter é puro, e a alma o vê tal qual ele entra. Mas se (o astro) for negro e não puro nem diáfano, significa uma doença,

indício da audiência do texto.

136 Relação com o cap. 63, em que se trata de pessoas de natureza seca.

137 Littré: Sís

138 i.e., leste.

139 i.e., leste e oeste.

140 A edição de Joly aponta o termo púfơta apenas no aparato crítico, atribuindo-o ao manuscrito $\theta$, mas não o insere no seu estabelecimento, traduzindo-o, entretanto. Ambos Jones e Littré o incluem nas suas edições. 
não por repleção nem por esvaziamento, mas por uma introdução externa. É caso para esse fazer uso de corridas circulares rápidas, de modo que a dissolução do corpo seja a menor possível e que, respirando o mais rapidamente possível, o que entrou seja expulso. Depois das corridas circulares, fazer caminhadas rápidas. Que se introduza uma dieta mole e leve por quatro dias.

13 Se parece receber algo puro de um deus puro, é bom para a saúde. Significa que o que entra no corpo é puro. Se ele parece ver o oposto disso, não é bom, pois significa que algo doente entrou no corpo. É preciso, então, que esse também seja tratado da mesma forma como o caso anterior.

Se lhe parecer $^{141}$ chover com água mole num tempo bom, sem chuva excessiva nem tempestade terrível, é bom. Significa, pois, que o sopro que entra do ar é equilibrado e puro. Se for o contrário disso, e chover excessivamente e houver tempestade e chuva de granizo, com água não pura, significa uma doença vinda do sopro que é inalado. Mas é preciso que esse também siga uma dieta da mesma maneira com muitíssimo poucos alimentos.

14 Então é preciso que quem conhece a respeito dos sinais celestes ${ }^{142}$, seja precavido, siga uma dieta e suplique aos deuses por bons [sinais], a Hélio, a Zeus celeste, a Zeus do lar, a Atena do lar, a Hermes e a Apolo, e pelos sinais contrários, suplicar aos deuses revertidos, tanto a Gaia, quanto aos Heróis, para que revertam tudo o que é difícil.

90

1 Estas coisas prenunciam saúde: ver ou escutar com acuidade algo sobre a terra, caminhar com segurança e correr com segurança, rápido e sem medo, e ver a terra lisa e bem trabalhada e as árvores frondosas e ricas em frutos e também cultivadas, ver os rios seguindo seu curso com água pura, nem muita nem pouca do que lhe é próprio, e ver as

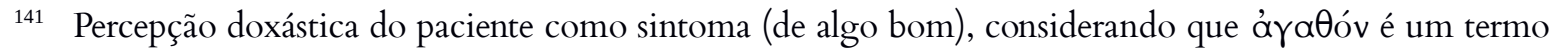
um tanto genérico do ponto de vista médico, e que, proveniente da $\delta$ ó $\xi \alpha$ do paciente, parece não ser suficiente para uma definição de saúde de uma forma mais completa.

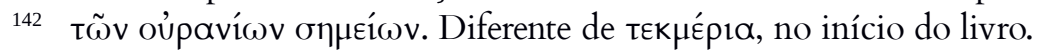


fontes e poços da mesma maneira. Tudo aquilo significa saúde para o homem, e que tanto o corpo, quanto todos os circuitos, as ministrações e as secreções estão de acordo.

2 Mas se vir o contrário dessas coisas, significa um dano no corpo. Quando se tem a vista e a audição danificadas, significa uma doença em torno da cabeça. Deve-se fazer caminhadas matutinas e muitas depois da refeição, ajustando-se à dieta anterior. Estando as pernas prejudicadas, deve-se fazer a revulsão com vômitos, e praticar mais lutas ajustando-se à dieta anterior.

3 Terra rugosa significa carne não pura. Deve-se exercitar com muitas caminhadas após a ginástica. A falta de frutos das árvores significa corrupção da semente humana. Se, então, houver queda das folhas na árvore, está-se danificado pela umidade e pelo frio; mas se a árvore brotar e não der frutos, está-se prejudicado pelo calor e pela sequidão. É necessário, por meio de dietas, secar e esquentar no primeiro caso, e esfriar e umedecer, no segundo.

4 Rios que não correm conforme indicam, quando correm em demasia, um aumento do circuito $^{143}$ do sangue, quando correm em menos, uma diminuição ${ }^{144}$. Deve-se, com a dieta, no primeiro caso aumentar e, no segundo, diminuir. E, fluindo impuros, significam perturbação. As agitações são purgadas pelas corridas e pelas caminhadas com sopro ofegante.

5 Fontes e poços significam algo em torno da bexiga, mas ${ }^{145}$ é preciso purgar com diuréticos. $\mathrm{O}$ mar perturbado significa doença do ventre, mas é preciso purgar com laxantes suaves e moles. Ver a terra ou uma casa em movimento ${ }^{146}$ significa fraqueza para um homem saudável, ou saúde para um homem adoecido, e também mudança do que

143 Joly (1960, p.106) assinala que termo $\pi \varepsilon p$ íodos, no genitivo, funciona como complemento dos termos

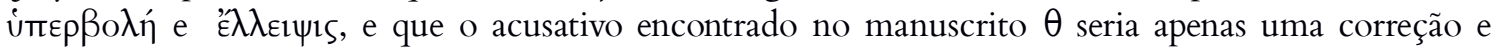

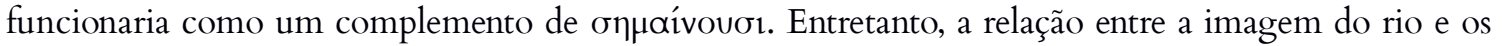
circuitos internos já fora explorada em capítulos anteriores. Por esse motivo, acredito que o genitivo seja mais plausível, e que, pela lógica interna do tratado, esteja ligado aos termos acima citados.

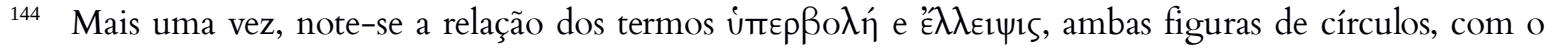
circuito do sangue.

145 Essa adversativa indica uma leve contraposição do tratamento oferecido àquilo que é prognosticado pelo sonho.

146 i.e. um tremor de terra. 
houver. Para o saudável, é caso de mudar a dieta: que vomite primeiro, a fim de receber novamente [os alimentos] aos poucos. Pois o corpo por inteiro se movimenta a partir do [alimento] que houver. Para o enfraquecido, é caso de fazer uso da mesma dieta, pois o corpo já muda a partir do seu estado presente. ${ }^{147}$

6 Ver a terra inundada de água ou de mar significa doença, havendo muita umidade no corpo. Mas é preciso fazer uso dos vômitos, do jejum, de esforços e de dietas secas e em seguida ministrar aos poucos o alimento, a partir de pouca quantidade. Mas ver a terra preta ou queimada não é bom ${ }^{148}$, mas há o perigo de ser desgraçado por uma doença forte e mortal. Significa haver na carne excesso de sequidão.

7 Mas é preciso suprimir os exercícios e o que do alimento for seco, quente, acre e diurético. Fazer uma dieta de tisana com uma decocção de cevada e com alimentos em pouca quantidade ${ }^{149}$, todos suaves e leves e muito vinho aguado e branco; tomar banhos quentes. Que não se banhe sem ter comido, deitar-se em uma cama suave, descansar, que se cuide do frio e do calor. Suplicar a Gaia e a Hermes e a todos os Heróis. Se lhe parece nadar em um lago, mar ou rio, não é bom, pois significa um excesso de umidade. É caso de ressecar com a dieta e fazer uso de muitos esforços. Para o que tem febre, [isso] é bom, pois o que o calor é apagado pela umidade.

91

Se alguém vir, em relação a si, algo conforme e de acordo com a sua própria natureza, nem maior nem menor, isso é bom para a saúde. Se ele vir uma veste branca em si e belíssimas sandálias isso é bom. Se algum [deles] for maior ou menor do que os membros, não é bom. Mas é preciso ora aumentar com a dieta, ora diminuir. As [vestes]

147 A mesma imagem tem ambos significados bons ou ruins. Faz sentido, então, que a dieta seja a mesma, apesar de se tratar de duas situações opostas.

148 Para Jones e Joly, trata-se de uma afirmação, um conhecimento epistêmico, portanto. Littré, seguindo o manuscrito M, registrado por Jones, mas sequer registrado por joly, prefere uma leitura doxástica e

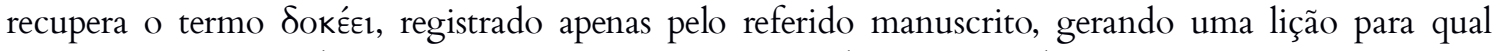
propõe a seguinte tradução: "ver a terra negra ou queimada não parece bom".

149 O manuscrito M registra "та̃ $\sigma 1$ toĩ 
negras, são mais nosogênicas e mais perigosas. Mas é preciso amolecer e umedecer. As [vestes] novas também significam mudança.

92

Ver os mortos puros em vestes brancas é bom. Receber deles algo puro significa saúde tanto dos corpos quanto do que se introduz [neles]. Pois os nutrientes, tanto os crescimentos quanto as sementes vêm dos mortos. Entrarem essas coisas puras no corpo significa saúde. Se ao contrário, os vir nus ou com vestes negras, ou não puros, ou recebendo ou trazendo algo de casa, não é favorável, pois significa doença, porque o que entra no corpo é danoso. Mas é preciso purgar com corridas circulares e caminhadas e ministrar ao que vomitou alimentos moles e leves.

93

Todos os corpos de forma estranha que aparecem nos sonos e amedrontam o homem significam pletora dos alimentos não habituais, secreção, [fluxo] bilioso e uma doença de aspecto perigoso. Mas é preciso provocar vômito e, ao longo de cinco dias, ministrar alimentos o mais leves possível, não em grande quantidade, nem acres e nem secos nem quentes, e, dentre os esforços, ministrar principalmente o mais naturais possível, exceto as caminhadas após o jantar. Fazer uso de banhos quentes e de repouso. Que se cuide do sol e do frio.

2 Quando no sono the parecer comer ou beber alimentos ou bebidas habituais, significa falta de nutrição e desejo da alma ${ }^{150}$. As carnes mais fortes [significam] um enorme excesso, as carnes mais fracas, um [excesso] menor; pois assim como porque o que se come é bom, assim também é bom o que se vê [no sonho]. Então, é caso de suprimir os

150 Essa passagem é diferente nas três edições consultadas. Joly aponta que a passagem foi "violentamente corrigida por Littré e é considerada como desesperada por Jones." Jones, de fato, classifica a emenda de Littré como ousada, porém aponta haver corrupção no texto que impedem uma tradução satisfatória dessa passagem. 
alimentos, pois significa um excesso de nutrição ${ }^{151}$.

3 Os pães preparados com queijo e mel significam a mesma coisa. Beber água pura não danifica, mas todo o resto danifica. ${ }^{152}$ Se o homem parece contemplar o que the é habitual, significa desejo da alma. Todas as vezes que ele foge amedrontado, isso significa interrupção do sangue sob a sequidão. É caso de umedecer e esfriar o corpo.

4 Todas as vezes que é combatido, espetado ou acorrentado por outro, significa haver ocorrido uma secreção contrária ao fluxo no corpo. É caso então de vomitar, fazer emagrecer, fazer caminhadas; e fazer uso de alimentos leves, ministrando-os depois dos vômitos por cinco dias.

5 Tanto vagar quanto subir com dificuldade significam a mesma coisa. Travessias de rios, hoplitas, inimigos e monstros de figuras estranhas significam doença ou loucura. É caso de utilizar poucos alimentos leves, suaves, moles e vômitos, e ministrar progressivamente por cinco dias. Fazer uso de muitos exercícios naturais, exceto depois do jantar, e resguardar-se de banhos quentes, do repouso, do frio e do sol.

6 Fazendo uso dessas coisas, conforme escrito, tornará sã a vida. Está por mim descoberta a dieta, até onde é possível um homem descobrir sendo acompanhado pelos deuses.

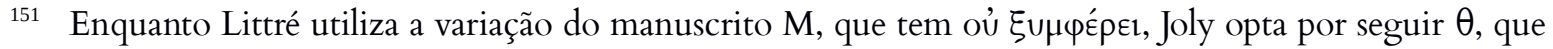
omite a negação.

152 Aqui também há discrepâncias entre uma edição e outra. Segundo Joly, "ces dernières pourraient faire à tort que l'auteur envisage une influence du rêve sur la santé. Il est bien certain que, par example, il veut dire "rever qu'on boit de l'eau pure n'indique pas qu'on soit en mauvaise santé". Les additions des manuscrits récents aux paragraphes 3 et 5 ont pour but d'expliciter la vraie pensé de l'auteur." 


\section{Conclusão ou a hermenêutica dos sonhos no Corpus hippocraticum entre o presente e o futuro}

Começo o fim desta Tese pela lembrança do quase ${ }^{153}$ hapax legomenon

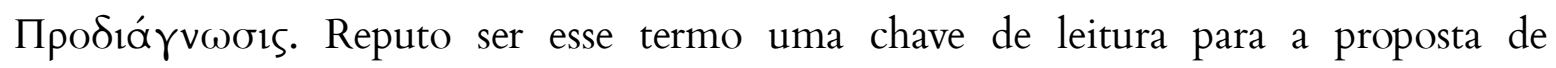
interpretação dos sonhos proposta pelo tratado. À diferença do conceito de $\pi \rho o ́ \gamma v \omega \sigma 1 \varsigma$

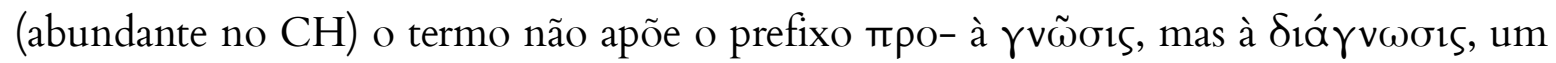
termo que expressa, em todo o $\mathrm{CH}$, a ideia de um conhecimento específico, relativo à natureza mesma da doença.

O primeiro passo foi, portanto, a constatação de haver um projeto maior do tratadista, que pretende, a partir das suas teorias a respeito do micro e do macrocosmos, instaurar um saber específico - uma oopín, que vê no sonho, produto exclusivo da alma, um material de outra ordem que pode ser aproveitado pela înт

As diferenças entre a prodiagnose e o diagnóstico são de ordem conceitual: enquanto este é a ferramenta com a qual o médico opera no âmbito da doença, a partir dos vovónfata, a prodiagnose, da mesma forma que a prognose, age no campo da saúde, com o fim de preservar e resguardar tal estado. Os oń sonhos indicam, no máximo, perturbações que podem ser revertidas por meio da sua ferramenta principal de terapia: a dieta. Por esse motivo, pouco importa a esse médico uma nosologia.

$\mathrm{Na}$ medicina antiga, o primeiro sentido de prognose é a predição do surgimento e evolução de uma doença. De certa forma, é possível pensá-lo como uma antecipação do futuro. Essa prática, entretanto, também inclui o conhecimento do estado presente do paciente, além de sintomas prévios, bem como aquilo que existe ou existiu no corpo do paciente. Além disso, ele implica em um conhecimento do próprio médico a respeito das

\footnotetext{
${ }^{153}$ Que só não pode ser definido como hapax legomenon, porquanto há precisamente duas ocorrências
} desse termo, ambas no Livro IV do Da dieta. 
ações do paciente, se as suas prescrições foram seguidas ou não, ou se houve transgressão das prescrições.

Esse conhecimento, quando não focado na previsão de determinada doença, serve de ferramenta para que o médico possa inferir certas informações sem que elas passem pela $\delta o ́ \xi \alpha$ do paciente, que, muitas vezes, pode fornecer informações incompletas ou errôneas, ou mesmo informações enganosas. Para Edelstein, essa habilidade de determinar antecipadamente o que acontece sem a necessidade de perguntar funciona como um meio de inspirar confiança e admiração e tem um forte componente que ele denomina "psicológico".

Graças ao seu estatuto na esfera do divino, o sonho ocupa um lugar de importância no imaginário grego. Isso pode ter facilitado a incorporação desse elemento ao fazer médico. Essa incorporação, no entanto, parece ter sido parcial, indicada pela ausência total do termo óva $\rho$ e seus derivados, que, em geral, assinalam uma visão no sonho. É possível que essa categoria de sonho tenha sido deixada de fora propositalmente

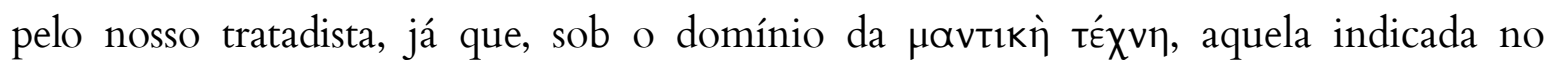
capítulo 87, não se qualificaria como útil ao seu projeto.

A previsão do futuro, do campo exclusivo do fazer mântico, é transposta para o campo do cuidado do corpo, próprio da medicina, que não nega, entretanto, os elementos da esfera do sagrado, cuidadosamente mencionados no seu texto. A alma, nesse sentido, com toda sua corporeidade, não perde seu caráter místico, a partir da sua relação mimética com o todo e da sua sutil relação com a vida e a morte, enquanto semente que sempre existe, como se vê no capítulo 2, e que é gerada a partir do que morre, como indica o capítulo 92 do tratado.

Essa alma tem seu lugar no corpo, como, de resto, é comum em textos hipocráticos que dela tratam. Entretanto, esse lugar, diferente dos outros, não é estático, mas caracteriza-se pelo movimento circular, tal qual uma revolução astral. Essa revolução da alma de que o nosso tratadista fala ocorre em torno da cavidade central do corpo e é a responsável por receber os estímulos advindos do exterior, que serão interpretados pela 


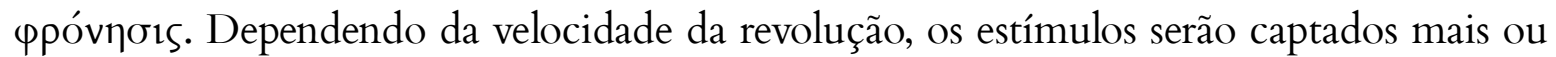

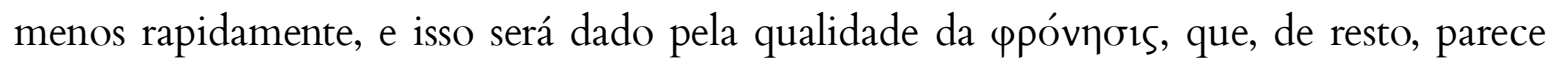
ser a única parcela da alma passível de modificação. A modificação da inteligência se dá durante a formação da semente e, é claro, por meio da dieta pode melhorar ou piorar.

A revolução da alma tem sua relação apomimética com a esfera macrocósmica. E é a partir da compreensão dessa relação que é possível chegar àquilo que, no último capítulo do tratado Da dieta salutar e início do Das afecções é considerado como o bem mais valioso que existe: a saúde. 


\section{Bibliografia}

ARISTÓTELES. Metafísica. Tradução de Giovanni Reale. Vol. II. São Paulo: Loyola, 2002.

ARISTOTLE. On the soul, Parva naturalia, On breath. With an English translation by W.S. HETT. London-Cambridge: Harvard University Press.

BAKKER, E. "Contract and Design: Thucydides' Writing” In: TSAKMAKIS A.; RENGAKOS A. (Eds.) Brill's Companion to Thucydides. Leiden: Brill, 2006. pp. 109-129

BARTOŠ, H. "Soul, seed and palingenesis in the Hippocratic de Victu". In: Apeiron. vol. 42, n.1. 2009.pp. 1-32

. "The concept of mimesis in the hippocratic de Victu". The Classical Quarterly, 64, 2014. pp 542-557.

.The analogy of auger boring in the hippocratic De Victu. The Classical Quarterly, 62, pp 92-97. 2012.

. "Dietetic therapy and its limitations in the hippocratic On Regimen". In: SUVÁK, V. (ed.) Sokratika: sebapoznanie a starost' o seba. Acta Facultatis Philosophicae Universitatis Prešoviensis. Prešov: 2009.

BOUDON, V. "Oral et écrit chez Galien”. In: JOUANNA, J.; LECLANT, J. La médecine grecque antique. Paris: Les Belles Lettres, 2004. p.199-218.

BURKERT, W. Lore and science in early Pythagoreanism. Cambridge: CUP, 1972.

BUTTI DE LIMA, P. L’inchiesta e la prova: imagine storiografica, pratica giuridica e retorica nella Grecia clássica. Torino: Giulio Einaudi editore, 1996. 
BYL, S. "Le vocabulaire de l'intelligence dans le chapitre 35 du livre I du traité du Régime". Revue de philologie, de littérature et d'histoire anciennes, 2002 - t.LXXVI. p.217224.

. "Sommeil et insomnie dans le Corpus Hippocraticum" In: Revue belge de philologie et d'histoire. Tome 76 fasc. 1, 1998. Antiquité - Oudheid. pp. 31-36.

CAIRUS, Henrique Fortuna. O vocabulário fisiológico do tratado hipocrático Da natureza do homem. Dissertação de Mestrado em Letras Clássicas. Rio de Janeiro: Faculdade de Letras da Universidade Federal do Rio de Janeiro, 1994.

. Os limtes do sagrado na nosologia hipocrática. Tese de Doutorado em Letras Clássicas. Rio de Janeiro: Faculdade de Letras da Universidade Federal do Rio de Janeiro, 1999.

- "A alma do corpo e o corpo da alma entre os gregos antigos". In: Calíope Presença clássica. n.15, dez. 2006. p.72-90.

. \& RIBEIRO Júnior, Wilson A. Textos hipocráticos: o doente, o médico, a doença. Rio de Janeiro: Ed.Fiocruz, 2005.

CAMBIANO, G., "Une interpretation 'materialiste' des rêves: Du Regime IV". In Grmek, M. D. (Ed.). Hippocratica: Actes du Colloque Hippocratique de Paris. Paris: 1980, pp.87-96.

CANGUILHEM, Georges. O normal e o patológico. Trad. Maria Thereza Redig de Carvalho Barrocas. 3a ed. revista e aumentada. Rio de Janeiro: Forense, 1990.

CALAME, C.; DUPONT, F. "L'énonciation en catalogue". Revue de l'UFR Lettres, Arts, Cinéma. Paris: Université Paris-Diderot, 2008.

COLLINS, D. Magic in the Ancient Greek World. Oxford: Blackwell, 2008. 
COMPTON, M.T. The Union of Religion and Health in Ancient Asklepieia. Journal of Religion and Health, Vol. 37, No. 4 (Winter, 1998), pp. 301-312.

CORNFORD, F. Principium sapientiae: as origens do pensamento grego. Lisboa: Calouste Gulbenkian, 1989.

COULOUBARITSIS, L. "Fecondité des pratiques catalogiques” Kernos 19 (2006), 249266.

DEAN-JONES, L. "Literacy and the Charlatan in Ancient Greek Medicine". In: YUNIS, H. Written Texts and the Rise of Literate Culture in Ancient Greece. Cambridge: Cambridge University Press, 2003. p.97-121.

DESCOLA, P., PALSSON, G. (org.). Nature and society. Anthropological perspectives. London: Routledge, 1995.

DUMINIL, M.-P. "Les emplois de dynamis dans le Corpus hippocratique". In: CRUBELLIER, M. et alii. DUNAMIS: autour de la puissance chez Aristote. Louvain: Peeters, 2008. p.15-25.

DUPONT, F. L'invention de la litterature: de l'ivresse grecque au texte latin. Paris: La découverte, 1998.

EDELSTEIN, L. Ancient medicine. Baltimore: The John Hopkins Press, 1967.

EIJK, P. VAN DER (Ed.) Hippocrates in context. Leiden: Brill, 2005.

. Medicine and Philosophy in Classical Antiquity. Cambridge: Cambridge University Press, 2005.

. "Towards a rhetoric of ancient scientific discourse". In: BAKKER, E.J. (Ed.)

Grammar as interpretation: Greek literature and its linguistic contexts. Leiden: Brill, 1997. p.77-129. 
. "Divination, prognosis and prophylaxis: The hippocratic work 'On Dreams' (De Victu 4) and its Near Eastern background”, in H. F. J. Horstmanshoff \& M. Stol (eds. ), Magic and Rationality in Ancient Near Eastern and Graeco-Roman Medicine, Leiden, 2004, p.187-218.

FOLEY, J.M. "What's in a sign", in: Mackay, E.A. (ed.), Signs of orality: the oral tradition and its influence in the Greek and Roman World. Leiden: Brill, 1999. p.1-27.

FREDE, D. and REIS, B. (Eds.) Body and Soul in Ancient Philosophy. Berlin-New York: Walter de Gruyter, 2007.

GAVRILOV, A.K. "Techniques of reading in Classical Antiquity", in: Classical Quarterly 47, 56-73.

GIL, Luis. Therapeia: La medicina popular en el mundo clásico. Madrid: Guadarrama, 1969.

GOODY, J. Cooking, Cuisine and Class. Cambridge: Cambridge University Press, 1982. . The domestication of the savage mind. Cambridge: CUP, 1977. . The interface between the written and the oral. Cambridge: CUP, 1987.

GÖRLACH, M. "Text types and Language History: the cookery recipe", in: RISSANEN, M. et alii. History of englishes: new methods and interpretations in Historical Linguistics. Berlin: Mouton de Gruyter, 1992.

GRANT, M. Galen on Food and Diet. New York: Routledge, 2000.

GRMEK, M.D. Hippocratica: actes du Colloque hippocratique de Paris. Paris: Éditions du CNRS, 1980.

HANKINSON, R.J. “Galen's Anatomy of the Soul”. Phronesis, Vol. 36, No. 2 (1991), pp. 197-233. 
HARRIS, W. V. Dreams and Experience in Classical Antiquity. Cambridge-London: Harvard University Press, 2009.

HARTOG, F. Le miroir d'Hérodote: essai sur la répresentation de l'autre. Paris: Gallimard, 1980.

HEINIMANN, F. Nomos und physis. Herkunft und Bedeutung einer Antithese im giechischen Denken des 5. Jahrhunderts, Schweitz. Beitr. z. Altert. Wiss., H. 1 Basel, 1945. (Versão de Mauro Engelmann).

HERODOTE. Histoires. Texte établi et traduit par Ph.-E. LEGRAND. Paris: Les Belles Lettres, 1946. 11vols.

HERSHBELL, J.P. “Empedoclean In־uences on the Timaeus," In: Phoenix 28, 1974, pp. 145-166.

HIPPOCRATES. With an english translation by W.H.S. JONES and E.T. WITHINGTON. London/Cambridge, Loeb Classical Library, 1923-92.

HOLMES, B. The symptom and the subject: the emergence of the physical body in ancient Greece. Princeton: Princeton University Press, 2010.

HOLOWCHAK, M. "Aristotle on Dreaming: What Goes On in Sleep When the 'Big Fire' Goes Out". In: Ancient Philosophy 16, 2, 1996. pp.405-423.

HORKY, P.S. "The imprint of the soul: psychosomatic affection in Plato, Gorgias and the "orphic" gold tablets". Mouseion, Series III, Vol. 6 (2006) 383-398.

JOLY, Robert. Le niveau de la science hippocratique. Paris: Les Belles Lettres, 1966.

. Recherches sur le traité pseudo-hippocratique "Du régime". Paris: Belles Lettres, 1960. 
- "Platon, Phèdre et Hippocrate: vingt ans aprés". In: La collection hippocratique et son rôle dans la médecine: Colloque Hipocratique de Strasbourg. Lieden: E.J.Brill, 1975. p.407-21.

. "Un peu d'epistémologie historique pour hippocratisants". In: Hippocratica: Colloque Hippocratique de Paris. Paris: Centre National de La Recherche Scientifique, 1980. p.285-99.

. "L'école médicale de Cnide et son évolution”, Antiquité Classique 47 (1978), p.528-537.

JOUANNA, J. Hippocrate. Paris: Fayard, 1992.

. Hippocrate et l'École de Cnide. Paris: Les Belles Lettres, 1974, 2009.

. Ippocrate e il sacro. In: Koinônia (12). Milano, 1988, p.91-113.

. La naissance de l'art médical occidental. In: GRMEK, Mirko D. (org.) Histoire de la pensée médicale en Occident: Antiquité et Moyen Âge. Paris: Seuil, 1995. p.2566.

- "Rhétorique et médecine dans la collection hippocratique: contribution à l'histoire de la rhétorique au Ve siècle", Revue des études grecques 97 (1984), p.26-44.

- \& BOUDON, V. "Remarques sur la place d'Hippocrate dans la pharmacologie de Galien”, in: DEBRU, A. Galen on Pharmacology: Philosophy, History and Medicine. Leiden: Brill, 1997. p.213-234.

. Greek medicine from Hippocrates to Galen: selected papers. Edited with a

preface by Philip van der Eijk, translated by Neil Allies. Leiden-Boston: Brill, 2012.

KESSELS, A.H.M. “Ancient systems of dream classification”. Mnemosyne, vol. 22, fasc. 4. 1969. pp.389-424. 
KING, H. (ed.) Health in Antiquity. London: Routledge, 2005.

KIRK, G.S. El mito. Su significado y funciones en la Antigüedad y otras culturas. Barcelona: Ediciones Paidós, 1985 (1970).

KIRK, G.S., RAVEN, J.E., SCHOFIELD, M. Os filósofos pré-socráticos. Lisboa: Fundação Calouste Gulbenkian, 1994.

KOSELLECK, R. Uma história dos conceitos: problemas teóricos e práticos. Estudos Históricos. Rio de Janeiro, vol. 5, n. 10, 1992, pp. 134-146.

LAÍN ENTRALGO, P. La medicina hipocrática. Madrid: Alanza Universidad, 1987.

LASSERRE, F. (Ed.) Formes de pensée dans la collection hippocratique. Geneva: 1983.

LE BLAY, F. "Microcosm and macrocosm: the dual direction of analogy in Hippocratic thought and the meteorological tradition". In: Van der Eijk, p. Hippocrates in Context. Leiden/Boston: Brill, 2005.

LÉVI-STRAUSS, C. Mythologies. 4 vols. Paris: Plon, 1964.

. 'Le cru, l'enfant grec et le cuit'. In: LE GOFF e NORA (eds.), Faire d'histoire, III. Paris: Gallimard, 1974, p. 137-168.

LLOYD, G.E.R. Polarity and analogy: two types of argumentation in early Greek thought. Cambridge: CUP, 1966.

. "Who is attacked in On ancient medicine?" Phronesis 8 (1963), 108-126.

. “The hippocratic question”, Classical Quarterly 25 (1975), 171-192.

. Magic, reason and experience: studies in the origins and development of Greek science. Cambridge: CUP, 1979.

. Methods and problems in Greek Science. Cambridge: CUP, 1991. 
. The revolutions of wisdom: studies in the claims and practice in Ancient Greece. Berkeley: University of California Press, 1987.

. In the grip of disease: studies in the Greek imagination. Oxford: OUP, 2003.

LONGRIGG, J. Greek rational medicine: philosophy and medicine from Alcmaeon to the Alexandrians. London: Routledge, 1993.

. "Presocratic philosophy and the Hippocratic dietetic theory", in GAROFALO, I. et alii. Aspetti della terapia nel Corpus hippocraticum. Firenze: 1999.

LONIE, I.M. "The Cnidian treatises of the Corpus hippocraticum", Classical Quarterly 15 (1965), 1-30.

. "A structural pattern in Greek dietetics and the Early History of Greek Medicine" Medical History 21, 235-260.

. "Cos versus Cnidus and the Historians: Part 1", History of Science 16 (1978a), $42-75$

- "Cos versus Cnidus and the Historians: Part 2", History of Science 16 (1978b), 77-92

. "Literacy and the Development of Hippocratic Medicine", in: LASSERRE, F., MUDRY, P. (Eds.) Formes de pensée dans la Collection hippocratique. Geneva: 1983, p.145-161.

LLOYD, G.E.R. "Who is attacked in On ancient medicine?" Phronesis 8 (1963), 108126.

. Magic, Reason and Experience: Studies in the Origin and Development of Greek Science, Cambridge/New York, 1979. 
. The Revolutions of Wisdom: Studies in the Claims and Practice of Ancient Greek Science, Berkely/LA/London, 1987

. In the Grip of Disease: Studies in the Greek Imagination, Oxford/New York, 2003.

LÓPEZ FÉREZ, J.A. Tratados Hipocráticos (Estudios acerca de su contenido forma e influencia): actas del VIIe Colloque international hippocratique. Madrid: 1992.

LORAUX, N. "Thucydide a écrit la Guerre du Péloponnèse", Métis, v.1, n.1, 1986.

LORENZ, H.The Brute Within: Appetitive Desire in Plato and Aristotle. Oxford: Clarendon, 2006.

MALONEY, G.; SAVOIE, R. Cinq cents ans de bibliographie hippocratique (1473-1982). Québec: Les éditions du Sphinx, 1982.

MARELLI, C. "Place de la Collection hippocratique dans les theories biologiques du sommeil" in F. Lasserre \& P. Mudry (eds. ), Formes de Pensée dans la Collection Hippocratique: Actes du IVe Colloque International Hippocratique (Lausanne 21-26 Septembre 1981), Lausanne 1983, 331- 339.

NUSSBAUM, M. C. \& OKSENBERG, A. Essays on Aristotle's De Anima. Oxford: Clarendon, 1995.

NUTTON, V. Ancient Medicine. London/New York: Routledge, 2004

OBERHELMAN, S. Dreams, healing, and medicine in Greece : from antiquity to the present. Surrey-Burlington: 2013.

OEUVRES complètes d'Hippocrate. Traduction, introduction et notes philologiques par Émile LITTRÉ. Paris, Academie Royale de Médecine, tomo I, 1839; tomo II, 1840; 
tomo IV, 1844; tomo VI, 1849; tomo VII, 1851; tomo VIII, 1853; tomo IX, 1861a; tomo X, 1861 b.

PEARCY, L.T. "Diagnosis as Narrative in Ancient Literature". The American Journal of Philology, Vol. 113, No. 4 (Winter, 1992), pp. 595-616

PERCEAU, S. La parole vive. Communiquer en catalogue dans l'épopée homérique. LouvainParis-Dudley (MA), 2002.

PETTIS, J.B. "Dream, and Healing: The Integration of Materia and Psyche in the Ancient World”. Journal of Religion and Health, Vol. 45, No. 1 (Spring, 2006), pp. 113129.

PIGEAUD, Jackie. Folie et cures de la folie chez les médecins de l'antiquité gréco-romaine: la manie. Paris: Les Belles Lettres, 1987.

PLATÃO. República. Introdução, tradução e notas de Maria Helena da Rocha Pereira. Lisboa: Fundação Calouste Gulbenkian, 1990.

- Timeu-Crítias. Tradução do grego, introdução, notas e índices: Rodolfo LOPES. Lisboa: Centro de Estudos Clássicos e Humanísticos, 2011.

PLATON. Timée - Critias. Texte établi et traduit par Albert Rivaud. Paris: Les Belles Lettres, 1985.

POWELL, O. Galen: on the Properties of Foodstuffs. Cambridge University Press, 2003.

ROTHWELL, K. Nature, culture and the origins of Greek comedy. Cambridge, Cambridge University Press, 2006.

SMITH, W.D. "Galen on Coans versus Cnidians" Bulletin of the History of Medicine 47 (1973), 569-585.

. The hippocratical tradition. Ithaca: Cornell University Press, 1979. 
. "The development of Classical Dietetic Theory", in GRMEK, M.D. Hippocratica. Paris, 1980.

. "Analytical and Catalogue Structure in the Corpus hippocraticum", in LASSERRE, F. Formes de pensée... Geneva, 1983. p.277-284.

TAFFIN, A. Comment on rêvait dans les temples d'Esculape In: Bulletin de l'Association Guillaume Budé, n³, octobre 1960. pp. 325-366.

THIVEL, A. \& ZUCKER, A. (Eds.) Le normal et le pathologique dans la Collection hippocratique. Nice: 2002.

THOMAS, R. Herodotus in context. Cambridge: CUP, 2000. - "Prose Performance Texts: Epideixis and Written Publication in the Late Fifth and Early Fourth Centuries", in: YUNIS, Harvey (ed.), Written Texts and the Rise of Literate Culture in Ancient Greece. Cambridge: CUP, 2003. p.162-188.

TRATADOS hipocráticos. Tradução, introduções e notas por Carlos GARCÍA GUAL (org.), Maria D. NAVA, J. LÓPEZ FÉREZ, B. ÁLVARES CABELLOS et alii. Madrid: Gredos, 1983-1990. 6 vols.

TOTELIN, L.M.V. Hippocratic Recipes: Oral and Written Transmission of Pharmacological Knowledge in Fifth- and Fourth-Century Greece. Leiden/Boston: Brill, 2009.

WEST, M.L. "The Cosmology of 'Hippocrates', De Hebdomadibus". The Classical Quarterly, New Series, Vol. 21, No. 2 (Nov., 1971), pp. 365-388.

YUNIS, Harvey (ed.), Written Texts and the Rise of Literate Culture in Ancient Greece. Cambridge: CUP, 2003. 